Portland State University

PDXScholar

5-7-1997

\title{
The Persistence of Elites and the Legacy of I.G. Farben, A.G.
}

Robert Arthur Reinert

Portland State University

Follow this and additional works at: https://pdxscholar.library.pdx.edu/open_access_etds

Part of the History Commons

Let us know how access to this document benefits you.

Recommended Citation

Reinert, Robert Arthur, "The Persistence of Elites and the Legacy of I.G. Farben, A.G." (1997). Dissertations and Theses. Paper 5302.

https://doi.org/10.15760/etd.7175

This Thesis is brought to you for free and open access. It has been accepted for inclusion in Dissertations and Theses by an authorized administrator of PDXScholar. Please contact us if we can make this document more accessible: pdxscholar@pdx.edu. 
THESIS APPROVAL

The abstract and thesis of Robert Arthur Reinert for the Master of Arts in History were presented May 7,1997, and accepted by the thesis committee and department.

COMMITTEE APPROVALS:
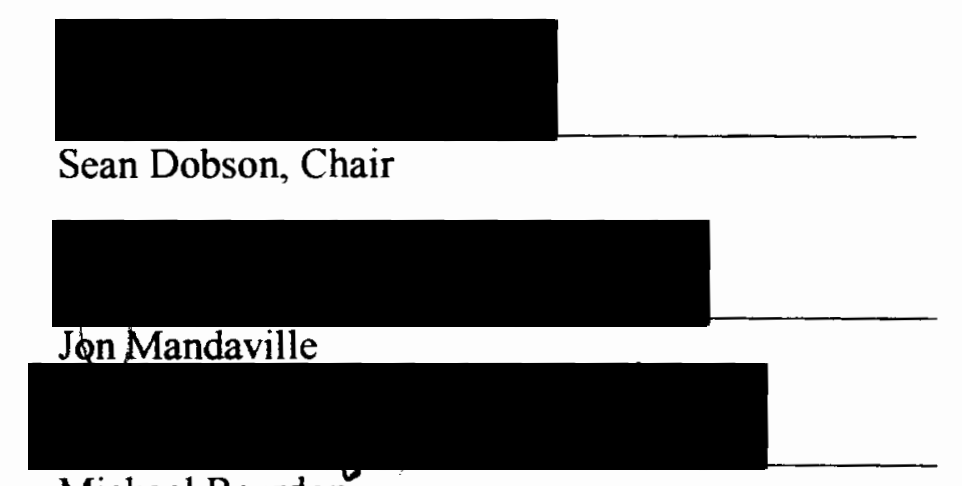

Michael Reardon

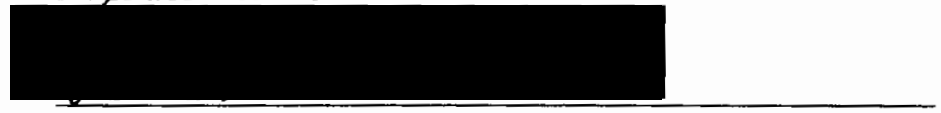

Louis Elteto

Representative of the Office of Graduate Studies

DEPARTMENT APPROVAL:

Gordon Dodds

Department of History

ACCEPTED FOR PORTLAND STATE UNIVERSITY BY THE LIBRARY

by

on

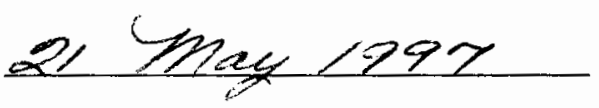




\begin{abstract}
An abstract of the thesis of Robert Arthur Reinert for the Master of Arts in History presented May 7, 1997.
\end{abstract}

Title: The Persistence of Elites and the Legacy of I.G. Farben, A.G..

On a massive scale, German business elites linked their professional ambitions to the affairs of the Nazi State. By 1937, the chemical giant, I.G. Farben, became completely "Nazified" and provided Hitler with materials which were essential to conduct war. With its monopoly over the manufacture of critical wartime products and global business interests, I.G. Farben became one of the most powerful companies in the world during World War II, and an integral part of the Third Reich power structure. The conglomerate also provoked hostile mergers within the conquered "territories" of the German Reich, and constructed one of the largest privately-owned synthetic oil and rubber factories in the world at Auschwitz, where extensive use was made of slave labor.

After World War II, companies like I.G. Farben faced the four-power occupation policies of de-Nazification and decartelization. Yet due in large part to the impending threat of Communism, key policies of the occupation governments were weakened or rendered inoperative. These same industries recovered swiftly and expanded production into foreign and domestic markets; indeed, I.G. Farben's three successor companies are now each bigger than their original parent company. Company executives tried at Nuremberg for their crimes and found guilty were given sentences of eight years or less, and many business leaders were able to resurrect their careers. Like many German firms of that era, I.G. Farben typifies the way in which Germany's top business leaders 
exploited the resources available to them and adapted their political allegiances during and after World War II to maintain their power.

Many believe that political interests drive business interests, when in fact, the case of I.G. Farben suggests a reciprocal influence between these sectors, and greater corporate influence during the Third Reich than is widely known. Particularly under an expansionary dictatorship, the state may be used by elites as an instrument to build and hoard capital, allowing elites to compete effectively on a global scale, and industry serves as the engine which fuels the territorial ambitions of the state. 


\section{THE PERSISTENCE OF ELITES AND THE LEGACY OF I.G. FARBEN, A.G.}

by

Robert Arthur Reinert

A thesis submitted in partial fulfillment of the requirements of the degree of

\section{MASTER OF ARTS \\ in HISTORY}

Portland State University

1997 
Page 2

\section{TABLE OF CONTENTS}

I. INTRODUCTION: THE PROBLEM 3

II. HISTORIOGRAPHY, METHODS AND SOURCES 6

III. ELITES WEATHER THE STORM 15

$\begin{array}{ll}\text { IV. I.G. FARBEN AND THE NAZI STATE } & 20\end{array}$

A. German Industrial Growth and the Founding of I.G. Farben 20

B. What is Good for I.G. Farben is Good for..... 26

C. A Meeting of Mutual Interests 32

D. The Rise of the NSDAP and I.G. Farben 37

E. Aryanization and the Changing Character of I.G. Farben 56

F. The Role of I.G. Farben in Slave Labor and Genocide 62

G. I.G. Farben: Preparing for Perpetuity 73

H. The "De-Nazification" of I.G. Farben 78

I. I.G. Farben: Post-War Metamorphosis $\quad 84$

$\begin{array}{lll}\text { V. SUMMARY } & 97\end{array}$

$\begin{array}{ll}\text { VI. CONCLUSION } & 99\end{array}$

$\begin{array}{ll}\text { BIBLIOGRAPHY } & 112\end{array}$

APPENDIX 1: Glossary of German Terms

APPENDIX 2: Letter from Hermann Schmitz to Adolf Hitler

Contributions to Hitler from I.G. Farben's Central Office, 1933-1944

APPENDIX 3: Sentences of I.G. Farben Board Members, Nuremberg War Crimes Trials APPENDIX 4: Positions of Farben Board Members Before and After 1945

APPENDIX 5: Order for the Deconcentration of I.G. Farben

APPENDIX 6: Translation of German Text by Footnote

APPENDIX 7: Organizational Chart, I.G. Farben, A.G. 


\section{INTRODUCTION: THE PROBLEM}

Every mouth finds its own cup of tea. The more inept something is, the more admirers it will attract, just as the worst things delight the greatest number, because most people, as we have said, are smitten with folly.

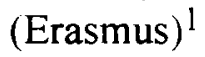

Solche Buecher laesst du drucken!

Treuer Freund, du bist verloren!

Willst du Geld und Ehre Haben,

Musst du dich gehoerig ducken. ${ }^{2}$ (Heinrich Heine)

I am investigating primary and secondary materials which provide critical insights regarding the character of modern social consciousness which excuse "crimes against humanity" for wisdom, reason, and the appearance of justice. Primary emphasis will be on German big business, particularly the chemical cartel of Interessen Gemeinschaft Farbenindustrle Aktiengesellschaft (Community of Interests of Dye Industries Inc.or I.G. Farben) during the Third Reich and including the Allied post-war process of de-nazification through 1953. The term "big business" is typically applied to large production organizations not owned by the state. Although in some cases the state may require economic planning to be conducted according to decisions by political authorities, big business has been generally left free to formulate its own policies according to its interpretations of market signals.

Central to my investigation is the extent to which a company's actions during the Third Reich were voluntary, and its postwar fate as a result of those actions. The logic,

I Reinhard P. Becker, editor, German Humanism and Reformation (New York, 1982), p. 91

2 Heinrich Heine, Lyrische Gedichte und Balladen (Pittsburgh, 1987), p. 140 
Page 4

as well as the irony, of this problem is that "the same creativity and adaptability that allowed German industrialists to embrace autarky and to prepare Hitler's armies with the tools needed for aggression -- qualities often exercised by the very same men -- were responsible for the success... under the new conditions of the postwar period."3

A further intent of this thesis is to offer a critical context for its readers by examining the importance of wealth in two very different, but related political structures; national socialism and democracy. In both systems, the debate about the essential character of elites has been highly contentious, particularly before the collapse of the Eastern Bloc economies. In general, there is no doubt that the National Socialists were enthusiastically subsidized by big business. Franz Neumann observed, "Fascism arose out of the need of economic power holders... not to react to the communist threat but to suppress the democratic movement which aimed at utilizing political power for the rational and social structuring of the economy."4 As usual, the economic power holders understood the path upon which they must build, and they took it.

The following interrelated questions will be addressed in this thesis:

1. How did nineteenth and early twentieth century German industry determine the development of German business in general, and I.G. Farben in particular, during the Second World War?

3 Raymond Stokes, Divide and Prosper (Berkeley, 1988), p.209.

4 Richard A. Grundberger, A Social History of the Third Reich (London, 1991), p. 217 


\section{Page 5}

2. What was the role of big business in Germany during World War II, as personified by the I.G. Farben company, and what was the nature of its symbiotic relationship with the NSDAP [ Nationalsozialistische Deutsche Arbeiterpartei] regime?

3. How did the end of the NSDAP regime impact I.G. Farben, and what was the disposition of the company and its assets during the post world war period?

4. What is the accountability of I.G. Farben for state-sponsored policies and practices which furthered its interests at the cost of human life?

Most members of the German economic elite were not Nazi ideologues or fanatic anti-Semites. Nevertheless, leaders of major corporations proved to be enthusiastic partners of the National Socialists once the latter had taken power in 1933. They were also generally committed to the Aryanization policies of the Third Reich and sacrificed the lives of innocent people for profit and in order to maintain a privileged position in German society. Besides claiming that "they had no other choice than to comply with the mandates of the Hitler government, ${ }^{5}$ business professionals outlined their defense after the war on grounds similar to those used by the common soldier and worker: by refusing to become an oppressor, they and their firms might have become victims. They had to protect themselves and their companies. Fear and 'opportunism' were blamed for their critical participation in Hitler's new world order. They believed their professional roles justified relief from moral responsibility.

5 Joseph Borkin, The Crime and Punishment of I.G. Farben (New York, 1978), p. 151 
As will be discussed in this paper, exploiting -- and ultimately expediting -- the genocidal political agenda of the Reich in the interest of profit became the standard operating procedure at I.G. Farben. And despite the devastating human consequences of their business practices, the post-war fate of the leaders of that company and others make a strong case for the durability of industrial and financial elites through changes of political regimes. Their seeming indestructibility is echoed in our time, which is marked by the post-Cold War zeal for all things capitalistic, and the explosion of an inherently borderless telecommunications industry whose chips represent the new means of production, and whose technical lingo is spoken in Boston, Botswana and Beijing.

While this thesis is by no means a definitive treatment of all aspects of the immensely complicated interpenetration of big business and the National Socialist State, it is an attempt to understand the essential nature of corporate elites in a specific company during a specific time period.

\section{DISCUSSION OF HISTORIOGRAPHY, METHOD AND SOURCES}

Wo kaeme der Heilige Geist hin, 'wenn er bei jedem Reim persoenlich anwesend sein muesste. ${ }^{6}$ (Erich Kaestner)

If business does not investigate itself, how can the historian investigate business? Added to the difficulty of documenting business practices in the context of a specific political regime is the tendency of companies to prohibit research into their archives and

6 Erich Kaestner, Die Kleine Freiheit (Hamburg, 1952), p. 115 
to settle legal problems out of court in order to maintain closed company records. An uncomplimentary history of a powerful corporation and its leaders may result in costly legal action. Such barriers have frequently discouraged scholarly ability and interest in the investigation of business history. As the historian Volker Berghahn proclaims, "[o]nly the 'capitalists' are still being exempted from the postulate of social science research." 7

While interpreting events with cultural astuteness, historians have frequently ignored or downplayed the roles of certain elite groups in history. Nevertheless, as we get further from any event, more material surfaces. This problem of bias and subjectivity in historical scholarship is often remedied (and blurred) by time, which encourages new interpretations of sources.

While seeking an acceptable approach to the study of German business history during World War II, I have been influenced by nineteenth century theorists such as Karl Marx. While Marx stated "[d]ie Geschichte aller bisherigen Gesellschaft is die Geschichte vom Klassenkampf,"8 his followers have further analyzed his concept of a class struggle as follows: mankind is divided into different classes and the elite class dominates, and is represented by the state. While classical Marxist theory "stressed the coercive role of the state to the exclusion of all else," Antonio Gramsci argued that the "ruling class is not only achieved by coercion but also elicited by consent. Gramsci also insisted that the state played a major role in cultural and ideological fields and in the organization of consent." 10 The fascist government of the National Socialists was

7 Volker R. Berghahn, The Americanization of West German Industry (Cambridge, MA, 1986), p. 8

${ }^{8}$ Karl Marx, Die Fruehschriften (Stuttgart, 1955), p. 525

9 Tom Bottomore, ed., A Dictionary of Marxist Thought (Cambridge, MA, 1983), p. 467 10 Ibid. 


\section{Page 8}

essentially capitalist in nature, as it opposed class warfare, exploited labor and defended private property. Industrial giants such as I.G. Farben flourished under their regime.

In some cases, I have had to filter the perspectives of some twentieth century sources whose historical interpretations too often reflect Cold War and post Cold-War attitudes. Although the theme of my research is limited to a specific time, the inferences are not.

It is a very convenient and psychologically satisfying way to present history by removing select important components of an era, which, we are told, need not be studied as a whole. Yet, traditionally, scholars have made their judgment about the general significance of their particular period or theme by determining where their story begins and ends in time. If we can accept that at the end of each writing of history, there is analysis and judgment, then research of an era such as the Third Reich, should begin at its end. Adolf Hitler and the political leadership failed to explore any alternatives at the end. Under Hitler's leadership, there was underlying determination to embrace "Valhalla" and the compulsive conviction that struggle for struggle's sake must continue to reach an absolute end. There was to be no surrender to the enemies of the Reich. Nor had the leadership made a serious attempt to avert the government's determination to lose totally and undoubtedly.

Occasionally, sociological research has been done on corporate "power elites," but history has been generally confined to discussions of diplomatic, political, and social histories, in which business remains in the background. There also exists a critical barrier to relating and revealing unpopular activity in the capitalist system. Particularly in capitalist societies, there is adherence to respecting individuals who have learned to combine a strong Promethean pride and ruthless individualistic defiance with financial success. The "Gesamtmensch universal genius ( as opposed to the ordinary 
Teilmenschen) is one who represents the maximum of purity, profundity, and selfmastery."11 Self-affirmation of life through financial "progress" has replaced the "weaker" false humanitarianism of the past. It is particularly in modern industrial nations, where corporate sponsorship of research programs has created a friendly environment for the larger business agenda. There is a "cultural" tendency of economics, business, and history scholars to avoid an in-depth study of improprieties by corporate management. However, regardless of national identification, one might ask whether there is an almost universal bias to protect those who manage the financial and industrial institutions: the privileged and indispensable elite.

Methodology in this significant area of business history has ultimately taken a back seat. The well-publicized fact that it was possible for respectable business executives in the Third Reich (and elsewhere) to have participated in and profited from the murder of millions of human beings without having lost their money and elite status, has been less palatable for Western historians than in the East. Among most MarxistLeninist scholars, a historical and scholarly exploration regarding National Socialist totalitarianism has always been preceded by a discussion of how reactionary German industrialists and Junker landlords chose their leader, the demagogic Adolf Hitler, "to enable them to maintain and extend the cartels which had become a characteristic form of business organization in the final monopoly stage of German capitalism."12 Since history in the Marxist view is perceived as a scientifically predictable process which is subject to certain laws, it is therefore not surprising for Marxists that National Socialism

11 Werner P. Friedrich. An Outline History of German Literature (New York, 1966), p. 186

12 Calvin B. Hoover, The Economy, Liberty and the State (New York, 1961), p. 161 
came to power "in a highly industrialized country with important natural resources, a well educated population, and an advanced technology."13

The state encouraged historians in the former German Democratic Republic (GDR), a country which had officially separated itself from the "Nazi past," to critically research the roles of business and the complicity of capitalist elites in the Third Reich. Hitler lived in a mansion, put his money in Swiss banks, and received royalties for the use of his picture on Deutsches Reich postage stamps. On the other hand, many of the former GDR elites, like Walter Ulbricht and Wilhelm Pieck, sat out the war in the Soviet Union. Unlike many leaders and elites in the West, they had not participated in Hitler's Reich and bore no burden of guilt. In the Soviet Zone, there was more of an official consensus that business elites were to be regarded as "class enemies". At least temporarily, elites found little encouragement to "restructure" in the East after the war. Contrary to the historians in the East, western historians have alleged that while industrial concerns are found to have used the NSDAP state apparatus to consolidate their domination of the domestic economy, the historical "facts" are far more complex. In fact, throughout history, an individual's ascendancy to dictatorial power has caused elaborate structural upheavals in societies.

The late Tim Mason believed that all good history writing begins at the end. If at the end of the story there is the legacy of World War II which transformed the character of modern social systems, there, at the beginning, are the Oswald Spenglers, Bertholt Brechts, and Kurt Tucholskys who foresaw it. At the end of the story, the National Socialist state ceased to exist, a self-sufficient German nation state ceased to exist, but in its place were two new socio-economic systems.

13 Ibid., p. 162 
Incomplete as it is, any cataloging of representative works on the history of German big business "thrives in measure as the experience of each historian differs from that of his fellows." 14 For the most part, the historian's experience is not simply associated with the past in "detached contemplation, but is identified as a social process shaped by the class interests and affiliations of the individual scholar." 15

In the absence of archival material from I.G. Farben and other World War II-era German companies, I have searched out other primary sources such as the autobiography of a Farben executive; a post-war government documentation of, and commentary on Farben-dominated cartels; an excerpt from the Nuremberg war crimes trial of the U.S. vs Carl Krauch (a wartime Farben executive); wartime journalistic accounts of the activities of the I.G. Farben group; books by Adolf Hitler and Albert Speer; and numerous comments by German executives and other first-hand witnesses which are quoted in the more than one hundred secondary sources I have consulted in the writing of this paper.

Depending upon their perception of culture and civilization, scholars have focused their attention upon questions which seem to be of greatest importance in interpreting the whole phenomenon. Two of my most informed secondary sources, Peter Hayes and Raymond Stokes are teaching history in departments of business and science and technology. Chief of the patent and cartel section of the Anti-trust Division in the United States Justice Department, Joseph Borkin was responsible for the war time investigation of the I.G. dominated cartels. His Crime and Punishment of I. G. Farben is an important primary source.

14 J.H. Hexter, "The Historian and his Day," from Reappraisals in History (Evanston, Illinois, 1962), p. 13

${ }^{15}$ Anreas Dorpalen, German History in Marxist Perspective (Detroit, 1985), p.46 
Joseph Borkin's basic agenda is to expose corruption at all levels of business and government. Supported by extensive documentation, Borkin traces the history of predecessor companies which would eventually become I.G. Farben, the world's production and distribution leader of synthetic dyesuffs during the first half of the twentieth-century. The author's narration includes relevant information of the chemical combine's participation during World War 1 , when the new technology of chemical warfare was made available. The former I.G. companies also pursued a slave labor program, which proved to be unsuccessful. The remainder of Borkin's book is primarily an account of the company's role in the economy of the Third Reich and the Nuremberg war crimes trials.

In addition to Borkin's indispensable material, Josiah E. DuBois' The Devil's Chemists and Generals in Grey Suits also deal with a critical look at the alliance of Adolf Hitler and I.G. Farben. DuBois, who was "chief of the prosecution staff for the I.G. case, ...and deputy to General Telford E. Taylor," 16 is a valuable primary source. Although his books are an essential reference, the author does not adhere to scholarly standards. Unlike his colleague, Joseph Borkin, DuBois does not give recognition to his sources. Both books were written in the early 1950s and there is little emotional distance between the writer and his work.

Relevant portions of general histories noted in my bibliography have been essential to my examination of business elites. D.G. Williamson's The Third Reich and Alan Wilt's Nazi Germany are brief narratives which cover significant features of the National Socialist State, while Martin Kitchen's Nazi Germany at War reflects the impact of Hitler's domestic policies during the war. Louis Snyder's Encyclopedia of the Third

16 Borkin, p. 147. 
Reich presents a definitive selection of historical information about the era. On National Socialist foreign policy, William Carr's Arms, Autarky, and Aggression offers a concise overview of government-business strategy during the first six years of Hitler's Reich.

A classic general work on business and industry is the sometime controversial German Business and the Rise of Hitler by Henry Ashby Turner. On individual firms which co-existed with I. G. Farben during the National Socialist era, Bernard Bellon's Mercedes in Peace and War traces the increasing wealth of the company as the Third Reich grew in power. Along with I.G. Farben, this leading arms dealer used thousand of foreign workers and concentration camp inmates as worker-slaves in their plants. Although not accepted by many scholars, William Manchester's The Arms of Krupp is a ambitious study of the great steel empire. Until Hans Mommsen's 1056 page book on Das Volkswagenwerk und seine Arbeiter im Dritten Reich becomes more widely available, the story of Volkswagen may be found in Walter Nelson's Small Wonder. Except for the narratives by Telford Taylor and others on the major criminals trial, there is no comprehensive book on the Nuremberg Trials. The 1947 and 1948 trials have received little attention by scholars writing in English. General works on Adolf Hitler are almost too numerous to recommend. Joachim Fest's Hitler is usually considered the "best" biography of the Fuehrer, but Alan Bullock's Hitler, A Study in Tyranny is also a classic. Mein Kampf is the major primary source since Hitler was not an avid writer. Other important primary sources of the era include Albert Speer's memoirs of Inside the Third Reich and Spandau are worth a critical investigation.

I found Volker Berghahn's definitive work on the transformation of Germany's capitalist system, The Americanisation of West German Industry 19+5-19.73 helpful, but at times, laborious. The main task of an economic interpretation of history or a historical interpretation of economics is to study "communities of life and kinship, of work and 
vocation, of property and enterprise, on the side of their economic results." 17 Richard Grunberger's excellent Social History of the Third Reich and Karl Hardach's Political Economy of Germany in the Twentieth Century provided a solid foundation of background sources for my research.

Throughout my readings, there is no source that gave me a greater "feel" for the anger in the "Valhalla" of the 1920s, 1930's, and 1940s than Julius Streicher's publication, Der Stuermer. Its redundant depravity reflects more than an anti-Semitic, racist pornography, as historians suggest; Der Stuermer represents a canker on modern society. Although it is likely that this publication was not at the top of I.G. Farben executives' reading list, its publisher did lead the campaign for the anti-Semitic legislation which culminated in the Nuremberg laws, from which major industrialists greatly benefited. Relevant articles in issues of The New York Times and Die Zeit were also useful. The World-Wide-Web also provided me with some source material, but the current confusion over the validity of massive historical information gathered by nonspecialists in the media and on the INTERNET has inhibited the scholar's search for historical accuracy and authority.

In acknowledging further debt to those who have preceded me with prior historiography on German big business, and in particular I.G. Farben, it would be appropriate to point out what has already been written on the topic. Near the top of the list is Alfred Chandler's ambitious study of Scale and Scope: The Dynamics of Industrial Capitalism which traces the evolution of the modern industrial enterprise and its organizational capabilities from the 1870 s to the 1970 s.

17 J.P. Stern, The Heart of Europe (Oxford, 1992), p.307 
Although Marxist historiography has not inspired much interest in the United States, the important Westem interpretation of German history by historians in the former German Democratic Republic is detailed in Andreas Dorpalen's German History in Marxist Perspective. It is a critical study of fundamental importance, particularly the chapters which discuss the era of state-monopoly capitalism. A collection of essays written by the late St. Peter's College historian, Tim Mason, addresses major debates in the historiography of National Socialism from a Marxist perspective in Nazism, Fascism and the Working Class. Also the East German accumulation of state archive materials which appear in their Braunbuch warrants a thorough investigation.

Despite shortcomings with certain secondary materials, I was able to extract pertinent information from The Arms of Krupp. The Splendid Blond Beast, The Fourth and Richesi Reich and other works of controversial nature.

\section{ELITES WEATHER THE STORM}

Competition is an accepted fact, but so are collective business decisions if they are imposed by the right people. ${ }^{18}$ (Ludwig Erhard)

When Birny J. Mason, former chairman and chief executive of Union Carbide died, his obituary as reported in The New York Times noted that he had become increasingly prominent when his company's profits began to grow and when "he took issue with government attacks on 'big business' simply because it was big. "Size confers no guarantee of survival," he said, noting that two thirds of the one-hundred largest

18 Edwin Hartrich, The Fourth and Richest Reich (New York, 1980), p 199 
companies in 1900 had vanished from that roster in 1958. The top is a slippery place, and is just as uncertain for big business as it is for small business," 19

Union Carbide, which solidly ranks today as among the nation's five-hundred largest industrial companies, "was a sprawling confederation of separate and even competing companies when Mr. Mason joined it in 1932."20 Chairman Mason might have been classifying Union Carbide's competitor, 1.G. Farben, in 1932, as one of those big businesses that had "vanished" from the roster in 1958.

Throughout history, the wealthy classes, noble and otherwise, have shared an interest in preserving the social order in which they prospered. Frequently displaying their power as entrepreneurs through corporate managers of labor, they like to think of themselves as rugged individualists, who as 'super-intendents' of large national and transnational corporations, are pioneers for a progressive world. Although the masses are likely to perceive them as role models, in reality, they function as bureaucrats in command of large hierarchical institutions.

At times, powerful conflicting interests cause discomfort at the top, but there "is no political class in history that has willingly and happily abdicated its possession of authority."21 In most cases, controlling elites have already acquired too much power to be successfully evicted from their upper echelons of society. Ralf Dahrendorf has stated that since there are always those who aspire to such eminence, the fascination with power inspires a curious inventiveness. Power is "almost invariably surrounded by ideologies of legitimacy, which adduce tradition, divine grace, or the law in order to support the establishment of those at the top. These ideologies are, strictly speaking, instruments of

19 The New York Times, January 9, 1997, p. A131. [an unsigned news story]

20 Ibid.

21 Ralf Dahrendorf, Society and Democracy in Germany (New York, 1979), p. 207 


\section{Page 17}

mystification...that enabled them [the elites] to retain their position despite all resistance and the onsiaught of modernity..." 22

Until the late eighteenth century, God or a divine being was often the medium used for legitimizing power. The rich and powerful aligned their assets with divinities and religion in order to maintain political stability, but with the "death of God" in nineteenth-century Europe, new belief systems were beginning to evolve. In part, due to the education of the European Bucrger, political ideas "trickled down" and guided the political action of the masses while transforming material life.

Although the members of the status quo still understood the world from its traditional perspective, they had to acknowledge the interplay of new ideas and ideologies in European political life. While during the past century the political environment assumed uneasy dimensions of discontinuity, the "traditional elite not only took the sting out of the aspiring bourgeoisie, but even managed to bind the growing labüor movement by the spell of its ideology of legitimacy." 23

In Germany and eisewhere, it was believed that incentives to gain wealth were based on merit rather than determined by priviieges bestowed by government. Wealth so easily translated into inequality and in opposition to free trade that capitalism generally thrived during the National Socialist regime of the Third Reich. Accordingly, even with a major break and the fall of Hitler's regime, political discontinuities did not inhibit the survival of groups in Germany, particularly the administrative and economic elites. Characteristically, there are exceptions where elites have not survived dramatic changes,

22 Ibid., pp 207-208

23 Ibid., p. 209 
such as in the Russian Revolution and the Maoist Revolution in China, but even then, some elites still weathered the storm.

Politicians have always been eager to do the bidding of wealthholders. Prior to the sixteenth century, trading companies in Spain, Portugal, Holland, and other European countries relied on the armed force of the state to assert their control of markets in the New World. Governments supplied these armed forces, while big business obtained resources and markets. By the turn of the twentieth century, European companies, not governments, controlled most of the trade in Asia and Africa. At the same time, North America was also involved with similar enterprising adventures. While public opinion in the United States was condemning European imperialism, U.S. corporate interests were also seeking to expand their markets in the Pacific and western hemispheres. Today, the owners of wealth are still accustomed to using economic power and military force to enrich themselves at the expense of the state.

All nations strongly protect property through laws. If political discontinuity occurs, measures are taken to restore order as soon as possible. Political discontinuities have rarely resulted in the complete loss of economic assets of the rich. By virtue of their inherited and economic positions, leaders of industry have had the income and ability to advance their interests in government. Since wealth is the cornerstone of the capitalist state, government bureaucracies provide opportunities for wealthholders with public service.

In relation to these wealthholders, top level government officials generally speak a common language, having attended similar schools, but can nonetheless develop diverse interests and opinions. They may even appear to be politically varied, but while their political interests (or disinterest) may apparently contradict their upper class social type, their social position always seems to remain intact. 
The striking discontinuities of modern political and social development have been generated from a social foundation of "elitist economic determinism," a system of philosophy that concludes that certain people have been "chosen" to control the rest. On one hand, these "determinists" presume the existence of human freedom, but demonstrate that some individuals make better choices than others. Since the domination of one economic class over others is widely taken for granted in industrial societies, the beneficiaries, both organizational and individual, are often not held liable for the practices nor consequences of seemingly "impersonal" market forces. Given the unique business opportunities presented by worldwide armed conflict, such elites actively employ the cover of "national interest" to further concentrate their collective and personal wealth regardless of whatever politically expedient structural adaptations may be required of them over time. The role of big business during the Third Reich and its aftermath exemplifies this.

Who are these elites who weather most storms of history? The terms industrialists, business elite, and financial elite, as used in this research, refer to the boards of directors and most senior management of the largest and most powerful cartels, companies and banks, plus the senior partners in law firms who cater to such clients. The German biographer and journalist Emil Ludwig commented on the role of this group in the Third Reich:

With Junkers and university teachers, who are first of all to be blamed for the downfall of the republic, a third class joined forces: the leading industrialists. It was those Kirdorffs, Krupps, Duisbergs, Bosches, Thyssens, Stinneses, and Vogelers who -- at the people's expense -- made their profit from Germany's defeat. Long before Hitler this pressure group fostered rearmament, which provided their plants with profitable contracts. They also financed the notorious Freikorps, which was to form the nucleus of the new army. They supported the Black Reichswehr, and made possible those sinister organizations which murdered so many, two 
cabinet ministers among them. In their laboratories new brands of poison gas were invented long before Hitler and sold to Japan. The I.G.F. (Farben) offered and later delivered its chemical secrets to Mussolini, and thus forced Italian chemical concerns into partnership. As early as 1931 Herr Duisberg could openly declare that "only an economic bloc from Odessa to Bordeaux can secure Europe's world position." 24

This sector has occasionally obtained public prominence through politics, but often remains behind the scenes. The United States National Archives in Suitland, Maryland contains a listing of about six hundred Germans who fit this description at the end of World War II; it can be found in the section identifying Names of Persons and Industrial Groups Affected by the Application of the De-Nazification Program' (1946).

Political leaders such as Joseph Goebbels, Arthur Rosenberg, and Rudolf Hess are rightly associated as agents of the infamous National Socialist regime. Military leaders such as Generals Keitel and Jodl have also been vilified. Most analysts seem to agree that they deserved severe punishment or death for their crimes against humanity. Nevertheless, the business Gemeinschaft (community) of the Third Reich did not share the same level of legal Verantwortlichkeit as political and military leaders.

\section{I.G. FARBEN AND THE NSDAP}

\section{IV.A. German Industrial Growth and the Founding of I.G. Farben}

Fuer wen, du gutes deutsches Volk

Behaengt man dich mit Waffen?

Fuer wen laesst du von Weib und Kind

24 Emil Ludwig, The Moral Conquest of Germany (New York, 1945), p. 121 
Und Herd hinweg dich waffen?25 (Gottfried August Buerger)

When Napoleon liquidated the Holy Roman Empire at the beginning of the nineteenth century, it was the final blow to an area of German states that had not favored political and economic unification. Unlike France and Britain, which had moved forward into the industrial age with overseas trade, economic expansion, and capitalist accumulation, the "un-holy, un-Roman, and questionable-Empire" of backward German provinces had remained weak due to its lack of political and economic unity. By 1815 , English goods began to flood the German markets and drove thousands of small, inefficient companies out of business. Three years later, a first step in the direction of a national union was taken with a tariff agreement among the German states; this was to become the forerunner of the important 1834 Zollverein (Customs Union) agreement which brought most German states together in a "common market" with the exception of Austria. Although the Zollverein was originally more agricultural and commercial than industrial, as the German states became more industrialized, duties were also raised on competing manufactured goods from outside the Verein. Nevertheless, due in part to its limited natural resources, German states remained economically backward until the early 1850 s.

While aspirations toward national unification formed the dominant ideology of nineteenth-century German statesmen, philosophers, economists, and historians, it also prepared the foundation for Germany's industrial revolution. Germany's rapid rise to industrial supremacy between 1870 and 1914 disturbed the balance of political, military and economic power among European nations. With financing from the humiliating

25 Jost Hermand, editor, Von deutscher Republik 1775-1795 (Frankfurt am Main, 1975), p. 129 
defeat of France in 1871 , Germany achieved political unification under the domination of Prussia. "Intoxicated with triumph,... the Germans -- each one of them, could conceive the belief that all this had been achieved exclusively by their own talents." 26

Chancellor Otto von Bismarck had deliberately used successive wars as an instrument not only to unify the German states, but to mobilize German industry. While German industrialization focused on chemicals, steel, optical goods, and electricity, a modern banking and financial system coincided with the creation of joint stock companies. The alliance between the banks and cartels would play a leading role in the German economy thereafter.

Germany had presented itself to the outside world as an authoritarian, militaristic semi-autocracy. At the same time, Germany began to threaten its neighbors' interests with its dynamic competitive drive toward industrial superiority. Carl Duisberg, founder of I.G. Farben, summarized his formula for success: "The object of any amalgamation of capital and production units... must always be the largest possible reduction in the costs of production, administration and sale, with a view to achieving the highest possible profits by eliminating ruinous competition." 27 Along with the general propensity toward national competitiveness, romantic cultural identification, militant patriotism, and a determined sense of pride in its "Germanic" work achievements, the young nation contributed greatly to the outbreak of World War I. World War I was one of the most significant "breaks" in modern European history. As Eric Hobsbawn has stated, it was felt to be the end of an era, the end of the world, made by and for the bourgeoisie. World

26 F.M Dostoievsky, The Diary of a Writer, translated and annotated by Boris Brasol (Salt Lake City, 1985), p. 733

27 Eric Hobsbawm, The Age of Empire (New York, 1989), p. 34 
War I would also become the first act in a continuous tragedy that would include the inter-war emergence of fascism and Europe's destruction during World War II.

In absolute terms, the defeat of the Germans in 1918 was deceptive. Although Germany was forced to accept the Treaty of Versailles and became a liberal republic, many conservative nationalists remained in positions of influence, serving as judges, high-level civil servants, military officers, professors, and teachers. These higher professional ranks remained the preserve of the old Imperial bureaucracy and were unsympathetic to the new republic, undermining its existence. For the post-war generation, they would become a reminder of the First World War as a failure of politics and society. There were simply not enough people in influential positions who wanted to see liberal democracy become a lasting reality in post-war Germany.

Since World War I had not been fought on German soil, its transportation and industrial resources had been left largely intact. At the same time, several German industries were burdened by the confiscation of their foreign investments, including patents and licenses in the Allied countries. As late as 1912, approximately "ninety-eight per cent of the applications for United States patents in the chemical field had been assigned to German firms and were never worked in the United States."28 In addition, German companies monopolized "eighty-eight per cent of worldwide production of dyes... (of) the world market." 29 Nevertheless, by 1917, the U.S. Government had seized U.S. patents held by German firms and later sold them to U.S. companies like DuPont, Eastman-Kodak and Union Carbide. By imposing high tariffs, the U.S. was also

28 David Noble, America By Design. Science, Technology and the Rise of Corporate Capitalism (New York, 1977), p. 16

29 Raymond Stokes, Opting for Oil (Berkely, California, 1995), p. 17 
responsible for temporarily blocking attempts by German firms to re-establish their prewar dominance in the U.S. market, particularly for materials such as organic chemicals.

The German labor situation was also conditioned by the post-war problem of rampant inflation which was created largely by the government's method of financing the war. On the assumption that Germany would win the war, the government chose to grant generous loans and to increase the volume of paper money in circulation rather than paying for it from taxes. Only six per cent of the cost of World War I was met by taxation. Industrial elites had calculated that they could meet current costs of production and pay off all war debts with a cheap mark and by a coordinated effort to ruin the credit of their country. Along with reparations, the financial result for Weimar Germany was the steep deterioration of the mark, combined with a temporary loss of foreign markets. This financial burden, a real cause of the German discontent which eventually contributed greatly to acceptance of Hitler, also opened windfall business opportunities for international bankers, cartels and companies such as the Hugo Stinnes conglomerate and I.G. Farben to profit by grotesquely inflating their debt payments. ${ }^{30}$

After Versailles, the United States temporarily withdrew into political isolation, while Great Britain encouraged a revival of German hegemony in order to restrain an apparent French dominance on the continent. In 1923, Germany defaulted in the payment of war reparations to the French, and the French retaliated by occupying the Ruhr. The German mark became worthless and by August of the same year, the exchange rate inflated to over four billion marks for one U.S. dollar. In part, due to the fear of the spread of bolshevism, financial intervention was in order. In 1924, the Allies appointed a committee of bankers to develop a program of reparations payment. Headed

30 David Marsh, The Most Powerful Bank (New York, 1992), p. 81 (loco citato) 
by Charles G. Dawes, the resulting "Dawes Plan" arranged a series of foreign loans totaling $\$ 800,000,000$ from dollar investors with proceeds going to Germany. ${ }^{31}$ These loans were used to a great extent to create and consolidate the gigantic chemical and steel combinations of I. G. Farben and Vereinigte Stahlwerke, respectively. Industrial mergers have always had a tendency to eliminate smaller and weaker firms. In Weimar Germany, there was no exception.

After the German mark was stabilized, I.G. Farben A.G. formally established a merger of the nation's six largest chemical companies, Bayer, Lucius und Bruening, Hoechst, Weiler ter Meer, Chemische Fabrik Griesheim-Elektron and BASF on December 9,1925 . This merger created the largest Chemiekonzern in the world. The Farben Group also quickly regained a strong position in the dye market in the United States. Badische Anilin und Soda Fabrik (BASF), largest of the firms and already a major shareholder in two of the other Farben companies, led in reorganizing the industry to meet the changed circumstances of market competition. By the 1930s, "General Aniline and Film, the newly created subsidiary of the huge German chemical combination I.G. Farben, had become one of America's largest chemical enterprises."32

During this period between the two world wars, I.G. Farben continued to spread a world-wide network of cartel relations, in which Farbenindustrie was often the dominating element in the cartels it entered. Through patent-pooling agreements and a wide network of "sales" agents, the Farben leaders were able to keep an eye on all new discoveries in other countries. Farben would reach its full corporate strength during the

31 Eberhard Kolb, The Weimar Republic, translated from the German by P.S. Falla (London, 1988), p. 60

32 Alfred D. Chandler, Scale and Scope (Cambridge, Massachussets, 1990), p. 173 
Third Reich. I.G. Farben and other cartels not only assisted Hitler in power after 1933; they also produced the bulk of key German war materials used in World War II.

\section{IV.B. What is Good for I.G. Farben is Good for......}

The important thing for industry is a strong state, a mighty and energetic government. (Carl Duisberg from his Lebenserinnerungen) ${ }^{33}$

One of the key questions that every student of history must ask is what role has the state played in the economy and what role has the economy played in the particular state. In the legal system of the United States, a corporation has the legal "rights" of an individual. If there are legal rights, there must also be legal accountability, yet the corporation is an inanimate entity, run by stockholders and their corporate representatives or board of directors. In capitalist economic systems like the United States and Germany, goods and services are produced for exchange according to the dictates of the market. In the United States and in Germany, wartime experience has often set the tone for later close identification between corporations and the state. The close identification of interest between a McDonnell-Douglas and the United States is analogous to the close identification of interest between I.G. Farben and the Third Reich. Thus, the question arises; who or what dictates the market?

In the early 1920 s, Germany was in chaos, in part, because it had failed to unify itself with institutions that were not solely the product of German efforts. With a need to create order, its national recovery was dependent on U.S. financial interests and monetary

33 Roy Lewis and Rosemary Stewart, The Managers (New York, 1961), p. 176 


\section{Page 27}

contributions. However, in just less than nine years after the Dawes Plan, the world would undergo a transformation with German industry at the heart of it.

Books and articles have appeared regarding the role of big business in financing Hitler's rise to power. Yet many scholars have refrained from or virtually ignored issues regarding the vital relationship between German business and the National Socialist state. To what extent does business determine politics, and to what extent do politics collaborate with business? Who really had the power in a modern society in which authority was divided between government institutions and the NSDAP? As Hitler pursued extremist policies, did his moderate supporters in industry continue to assume that the political rhetoric was unimportant, and that Gleichschaltung with Nazi goals may be used as a means to an end? Massive public works projects lessened unemployment, and built an infrastructure for a prosperous wartime economy. Hitler's initial domestic and foreign policies were successful, emboldening him and German industry still further.

In the same vein, the common European had entered the First World War with an adherence to authoritarian elitism, but when he left the battlefield in 1918, there was a sense that was given full expression in the generation that followed: a generation that would assert it was the "natural right" of the strong to rule the weak. For any nation such as Germany to accept subjugation and obedience was considered anathema. The master mentality, which had previously characterized the aristocratic and ruling classes, was now internalized by the common people. The Germans and other participants of the seemingly inevitable Second World War would turn natural moral values upside down in a struggle to overcome the humiliation of the lost war. In Germany, the bourgeois "slave mentality" of pre-1914 re-invented itself "beyond good and evil" in the nationalist ideology of Adolf Hitler. Action was still to be determined from above, but the 
"Christian-humanitarian" world of pre-World-War I, was replaced by "a state of isolation,... controlled and manipulated by a bureaucratic elite. 'Bureaucratic' in the sense that all spontaneity is denied, and that all action is mechanically determined by orders from above." 34

At the same time, powerful elements in German society successfully prepared for a post-war re-organization period. German shopkeepers, professionals, and big business had not bought into the Nazi ideology entirely, particularly when it seemed to be at its end. Analysis of the history of these and other groups in the Third Reich require a broader analysis than is possible here.

While scholars have proven that it is possible to write about aspects of cultural and social development within a country without being specific about larger issues, such as its place as a world power or its historical background, there is no aspect of Germany under National Socialism that can have historical meaning unless it is also firmly related to the era. There are strong modern pressures to research a particular subject as not being part of a whole political, social, and economic system. Many scholars assert they would rather work out general issues in their specific studies. Nevertheless, the motives of business elites within the Third Reich, or for that matter any modern society, might not be so easily overlooked if we did not so often view systems of government as being the engine driving society, rather than a vehicle being driven.

The Third Reich was not an anomaly. Its structure, citizenry, and modern social order with complex interdependencies did not, in an instant, simply appear on the face of the map of central Europe in order to campaign for death and destruction. Nor was the

34 Martin Kolinsky, Continuity and Change in European Society (New York, 1974), p. 93. 
Third Reich mereiy a terrifying chapter in the history of capitalist imperialism. After all, it was Hitler who claimed to be a "National Socialist". In short, the Third Reich, in its need to externally impose norms of behavior which would be beneficial to their idealized state, depended upon the support of traditional enclaves of power to be enthusiastic partners.

Modernization and economic development during the Third Reich was carried out under authoritarian direction in which big business eventually supported. "[I]ndustry held a significant leverage in both the (Nazi) party and the army, (while) business power was protected by Party and State: not subordinate to them." 35

Not bound to politics in the narrow sense, the enthusiasm that bound big business to National Socialism was a desire for stability, a stability which served as an inducement and rationalization which a society can offer for compliance for refraining from critical examination of its functioning structures. At the time of Hitler's rise to power, German industrialists were particularly fearful of the idea of a Communist revolution. Their fears were real, since "a leftist coalition of the Communists (KPD) and Social Democrats (SPD) could have held a higher percentage of popular votes in the critical German elections of November 6, 1932 than Hitler's National Socialist Party if they would have combined their efforts. A unified KPD and SPD coalition could have accounted for $37.2 \%$, while the NSDAP had $33 \%$, a $4.2 \%$ decrease in popularity from the July 31,1932 vote." ${ }^{36}$ The combined votes for the KPD and SPD increased by $1.5 \%$ from July, 31,1932 , and the November 6 th vote and ironically equaled the highest per cent of NSDAP votes up until that time. German elites understood the possible repercussions of

35 Kolinsky, p. 121.

36 Alfred Grosser, Germany in Our Time (New York, 1971), p. 12 loc. cit. 
a Russian-style communist revolution, particularly "with the ever more threatening... large-scale political strikes spreading, especially in Hamburg and Berlin. In these strike movements the mutually hostile, embattled comrades, the National Socialists and Communists... worked hand in glove." ${ }^{137}$ German elites believed they understood all too well what a "communist" takeover would mean in Germany. On the other hand, National Socialism had less of an international heritage than Communism. Economic historians such as Gustav Stolper, who was also a liberal member of the Reichstag from 1930-1932, were mindful of this view.

Nostalgia for a more primitive and war-like kind of society was found more in NSDAP rhetoric than in directives of its leaders to standardize and mechanize the country's labor. Competitive industrial efficiency was incorporated into the apparatus of the Third Reich in order to reestablish Germany's powerful pre-World War I industrial and military position in the world. These conditions "could be produced only by a stepby-step expansion of the area of Central Europe under German control. Only the economic potential of a Greater German Reich, enlarged by annexations and the creation of satellite states, ${ }^{138}$ could be self-sufficient and reduce its dependency against superior economic powers.

Another measure taken by the NSDAP to promote a reassuring stability during its first few months was a decree denouncing non-Aryans and persons married to nonAryans as undesirable 'foreign' influences in the Thousand Year Reich. The NSDAP and the SS ( Schutzstaffel), not the industrial and financial elite, initiated the the Aryanization laws as well as the Holocaust. But financial incentives to the German

37 Gustav Stolper, The German Economy: 1870 To the Present, Translated from the German by Toni Stolper (London, 1967), p. 123

38 Tim Mason, Nazism. Fascism, and the Working Class (Cambridge, 1995), p. 104 


\section{Page 31}

business community to participate in the persecution, dispossession and later murder of Jews and selected minorities were necessary to gain the support of the corporate establishment.

Durnng his rise to power, Hitler courted many industrialists, who sympathized with his xenophobic nationalism, but corporate financial power in Germany generally perceived Hitler as a force against the Bolshevik threat of a domıno-effect spread of world communism. At the same time, major industrialists saw in Hitler the man who would curb labor and provide them with lucrative government orders.

The fascist movement in Germany emerged as a result of the political, economic, and social crisis atter Worid War I. It generated an extreme anti-socialist, nationalist, imperialist, and racist ideology. On the surface, the political structure of National Socialism was marked by total control of the press and all information sources, massive propaganda campaigns, a single party system, and a dictatorial leader. At the same time, the NSDAP's attempt to coordinate all political, oconomic, social and cultural institutions of the Third Reich proved less successful due to the fact that various fascist leaders were so caught up in their ideological gloritication of "struggle" (Kampf) and competition that coordination between administrative units was most often lacking. International business elites opposed autarky and the bloc concept of German industrialists. "National Socialism presented itself to the elites across the Atlantic as a ruthless, expansionist, autarkic system, backed by German industrial cartels which had financed the rise of the Nazi Party." 39 Hitler's regime pursued a policy of Gleichschaltung, a term used in electrical engineering which means bring into line or coordination; in this context, it meant that all organizations, including businesses, were to serve the state. 'The

39 Berghahn, p. 39 
significance during the latter years of the Reich, of quarrels between business leaders and party officials over a proper plan for Gleichschaltung, was that it showed industry's preparation for post-war planning upon the dissolution of the Reich. Just as the Kaiser was replaced after World War I, industrialists presupposed that Washington would demand dissolution of the cartels, autarky and the bloc system, while German corporations could continue to remain intact. As in 1918, elites believed they would weather another national crisis.

\section{IV.C. A Meeting of Mutual Interests}

Man soll seine Wuerde nicht ausser Acht lassen. - Unter Moral verstehe ich das reele Produkt zweier imaginaeren Groessen. Die imaginaeren Groessen sind Sollen und Wollen. Das Produkt heisst Moral und laesst sich in seiner Realitaet nicht leugnen. ${ }^{40}$ (Frank Wedekind)

A price war is of benefit only to the consumer. ${ }^{41}$ (I.G. Farben to Winston Churchill, 1934)

The efficient individual is the one whose performance is an action insofar as it is the proper reaction to the objective requirements of the apparatus, and his liberty is confined to the selection of the most adequate means for reaching the goal which he did not set. ${ }^{42}$ (Herbert Marcuse)

Herbert Marcuse's observation in the "Social Implications of Modern Technology" hardly justifies modern man's compliance with the mechanistic process. He points out that the attendant whose duty is to keep pace with the process "supplements

40 Frank Wedekind, Fruehlings Erwachen (Munich, No Date), p. 74

41 I.F. Stone, The War Years 1939-1945 (Boston, 1988), p.208

42 Andrew Arato and Eike Gebhardt, The Essential Frankfurt School Reader (New York, 1993), p.142 
the machine process rather than makes use of it." 43 Typically, he must be directed in order to be mastered, and acquire the mechanical norms of those who put his efficiency to good use. Those dependent on the growth of large-scale industry can hope to assert their interests effectively only if this process can be effectively coordinated in a largescale organization. These "organization" individuals thereby cease to be isolated and are stripped of their self-interested pursuits. As a member of the crowd, acceptable impulses can easily be released, without personal responsibility This applies to both upper and lower ends of the social scale.

Corporations and their agents have historically understood, "complied with," and directed the process that pursues profit even when that pursuit promotes seemingly selfdefeating or immoral ends. How else could one explain the sale of American scrap iron to Japan in the 1930s, after it had already invaded China? Why were there no economic sanctions against Italy when Abyssinia was invaded in 1935, and why did main characters, defendants in the most far-reaching criminal trial in history, receive such lenient sentences for their major roles in the Third Reich's slave and death camps? According to a count by Corwin Edwards, there were also American firms in the 1930s which "were suspected of helping German rearmament and of promoting a dangerous arms race. 144

In modern German history, government authority had, for the most part, supported the marked feature of German industry, the cartel. Industry and government were both suspicious of and feared liberalism and communism. At a time when corporations still claimed national loyalties, the struggle against communism, for or

\footnotetext{
43 Ibid.

44 Berghahn, p. 37
} 
against free markets, and the Depression promoted coilaboration between Farben and NSDAP leaders. This mutual interest often included anti-Semitism.

Early in the Third Reich, there was an indication that the National Socialist government would favor the business community, since the regime did appear determined to implement its own form of cartel movement in which "[r]epresentatives of the cartels acted as efficiently within the Nazi bureaucracy as they had in their own organizations. "45 When Hitler explicated his "socialism" by underscoring "the necessity of private property and of economic order based upon the profits system, individual initiative, and inequality of wealth and income, many were reassured that... if he achieved power, business would rule the roost." ${ }^{146}$ In realistic terms, the word socialist in the name of the NSDAP party did not refer to the nationalization of the means of production, but rather to requiring the economy to serve the interests of the state. "Business is only one function of the body politic. ${ }^{n 7}$ The government was able to take advantage of the disastrous conditions of mass unemployment and the Depression, by destroying the organizations of the working class, and subjugating it to NSDAP rule; an ideological image of a classless society was to be proved a fiction. Hitler's regime was shown to be concerned with implementing the Mittelstandsideologie no further than was compatible with the requirements of industrial preparation for war.

It is obvious that the Third Reich's leaders were not so ideological in their thinking as to exclude from their Gemeinschaft capitalist leaders, or even "certain Jews (who) were officially classed as economically useful (wirtschaftlich wertvoller Jude)" 48

\footnotetext{
45 Louis Snyder, Encyclopedia of the Third Reich (New York, 1989), p 179

46 Lewis and Stewart, p. 176

47 Adolf Hitler, Duesseldorf Speech to Rhineland Industrialists, January 27, 1932 cited and translated by Louis Snyder, Hitler's Third Reich (New York, 1988), p. 60 48 Grosser, p. 46
} 


\section{Page 35}

during the early days of Hitler's Reich. Party leaders may have openly revered the soul of German soil, blood, and folkdom, but in practice, the Third Reich was a modern capitalist state. The ideal social type was not the farmer; it was the capitalist who could contribute most to the "greatness" of the state. In both the developed and the developing societies, the ideal social type is "the professional expert, who alone amongst the nonproletarian classes enjoys ungrudged, unchallenged prestige and security." 49

According to Perkin, this ideal human finds the "meaning and purpose in life in serving God or the Five-Year Plan." 50 The economic results of these business celebrities who claim to be utilizing God or Five Year Plans are usually concealed under the auspices of higher calling to "public service," while they, themselves, are more likely to be involved with profits and power. For example, our way of life is more accepting of "white-collar crimes" such as large-scale embezzlement and corporate fraud, than the average petty theft. The "white-collar criminal" is almost always the recipient of greater leniency in the courts, because he or she "made a single mistake." It is easier to sentence a "common criminal" than an influential businessman. If the legal courts of a society pronounce the fraudulent dealings of the influential businessmen as acceptable behavior, it is not surprising that "Nazi" business elites were also granted leniency due to their unique positions in one of the most advanced modern societies. Nevertheless, it would be too easy to dismiss all business cultures as one and ultimately over-simplify motivations in the world of business.

American scholars such as Henry Ashby Turner have asserted that Hitler kept an iron hand on business, and that business leaders were coerced into unquestioningly

49 Fritz Stern, The Varieties of History (New York, 1973), p. 448

50 Ibid. 


\section{Page 36}

obeying the Fuehrer's will. Although these scholars have argued that I.G. Farben was dependent on, and a mere instrument of the National Socialist state, industrialists also hated their dependence on bank creditors during the Weimar years. Financiers, "international Jewish finance - in the Depression - made businessmen so anti-Semitic that they failed to realize that the regime (NSDAP) intended to control and even own them too." 51 Industrialists blamed Weimar's financiers for Germany's problems too.

But corporations in Germany during this period were not in business solely to make money or even mainly to reap large financial profits. Although there were multinational power struggles within the companies themselves, German business elites generally believed in loyalty to the nation, particularly when it was profitable. Baron Georg von Schnitzler, a Vorstand (managing board) executive for I.G. Farben stated the following at the post war Nuremberg Military Trials:

"--[d]ass die I.G. eine Richtung verfolgen wuerde, welche nicht im Einklang mit der Regierung stand, war undenkbar, und dass die I.G. von einem Befehl der Regierung abweichen wuerde oder die Haltung einer offenen oder heimlichen Opposition einnehmen werde, kam gar nicht in Frage, selbst damals nicht, als Deutschland ein demokratischer Staat war, in welchem Regierungsmassnahmen oft kritisiert werden konnten. Die I.G. war Regierungstreu unter Stressemann ebenso wie unter Bruening und Papen."52

The I.G. was generally Regierungstreu during the Hitler regime too.

Labor, too, was drawn into the Gleichshaltung. Influential labor organizations of the industrial Mittelstand were dissolved and their members were forced into the membership of a newly created Estate for Handicraft and Trade. Later, the Reich's

51 Lewis and Stewart, p. 177

52 HGST, "Ein Konzern steht vor Gericht," Die Zeit, February 12, 1948, p. 8 
Minister of Economics, Hjalmar Schacht reduced the status of the organization putting it under the control of big business. At the same time, money was being pumped into the National Socialist regime. In open contradiction to the original NSDAP program, "the years 1933-36 saw a steady growth of cartels and the influence of big business over the economy - between July 1933 and December 1936, for example, over 1,600 new cartel arrangements were signed." 53

\section{IV.D. The Rise of the NSDAP and I.G. Farben "...without Farben, no foreign policy was possible." 54 (Stresemann)}

The cartelization of German industry contributed to a bloc mentality. While perceiving the world in terms of closed blocs, entrepreneurs behaved almost like bureaucrats. "After the Ruhr steel industry, I.G. Farben slowly began to turn its back on the world market. Speaking on 24 March 1931 (Carl) Duisberg seemed to be moving away from his internationalism when he talked of a 'closed economic bloc' from Bordeaux to Sofia." 55 After 1933, cartels became compulsory for the entire German economy. Although the state had the power to form and regulate membership in cartels, top cartel representatives and elites maneuvered as efficiently within the National Socialist bureaucracy, as they had in their own businesses.

While it is not my purpose to investigate the hierarchical structure of German industry, it is necessary to clarify briefly that German companies are controlled by a two-

53 D.G. Williamson, The Third Reich (London, 1982), p. 28

54 Josiah E. DuBois, Generals in Grey Suits (Boston, 1953), p.303

55 Berghahn, p. 24 
tiered board system. In keeping with German company law, there is a supervisory board known as the Aufsichtsrat and an executive board or Vorstand. The Aufsichtsrat or AR

broadly represents the shareholders who in fact elect it, while the function of the Vorstand is to manage the company. As the name suggests, the AR is responsible for supervision. To it must be reported company strategy, turnover, profitability, liquidity, and any important financial matters at least four times a year. It has the powers to hire and fire the members of the Vorstand and to set their remuneration. It has the ultimate sanction over all major investment decisions, the closure of plants and takeovers. ${ }^{56}$

Third Reich law empowered the Generaldirektor (head) of the Vorstand to resolve disagreements among the board members by asserting his power and running the company his own way. However, it was not until 1966 that German law required the Generaldirektor to submit to the majority vote of the Vorstand. However, we are more concerned with the role of elites of the two-tiered boards during the Third Reich and the immediate post-war period.

I. G. Farben was one of the most powerful companies in the world. It was aligned to 2,000 cartel agreements, had a share in three hundred eighty German firms, controlled five hundred firms in ninety-two countries, and manufactured forty-three major products. Its products were diversified to include dyes, oil, rubber, nitrogen, aluminum., and synthetic silks. Farbenindustrie had its own mines for coal, magnesite, gypsum and salt

During World War II it controlled some nine hundred chemical factories inside Germany and in the occupied territories, supplied the Wehrmacht with eighty-five per cent of its explosives, and produced almost all the synthetic tires that kept the Nazi war machine rolling. It presented to the

56 Anthony Rowley, editor, The Barons of European Industry (New York, 1974), p. 27 


\section{Page 39}

government an annual bill of at least one billion dollars...(and) had at its command an army of scientists, industrialists, statesmen, spies, saboteurs, and conspirators. ${ }^{57}$

Its international cartel agreements were made to include such major corporations as Standard Oil of New Jersey; Dow Chemical Company; CDC - Continental Dye Cartel (Ciba, Sandoz, and Geigy); E.I. du Pont de Nemours and Company; Mitsui, Japan; and second only to Farben in Europe, ICl - Imperial Chemical Industries of Great Britain. (In 1932 ICI joined CDC.)

As an example of I.G. Farben's business connections, German channels were firmly established in the United States. Because of buna synthetic rubber, strong links were established between I. G. Farben, Standard Oil Company and Ford Motor Company. Ford Motor Company built a vast factory in Cologne, and used it to manufacture cars for Central and Eastern Europe. The concentration camp at Buchenwald would later provide slave labor for this Ford factory ${ }^{58}$ Although these German subsidiary corporations were not run from the United States during World War II, as has been alleged by some Marxist historians, it is true that "the German directors and trustees who did manage these factories during the war...were to a large degree the same German bankers, lawyers, and corporate leaders who had been appointed by the parent companies in the U.S. to run these facilities prior to the war, and who often continued in their posts after the conflict ended." 59

During the Reich, National Socialists leaders asserted that the common interest must precede individual interest, but major corporations such as I.G. Farben continued to

57 Snyder, Encyclopedia of the Third Reich, p. 178

58 see Christopher Simpson, The Splendid Blond Beast (Monroe, Maine, 1995), p. 96

59 Ibid., p. 97 
assume greater responsibility for the overall course of the German economy. Since their ideology pledged "the complete confiscation of all war profits, the nationalization of all combines (trusts)... and [that]the great industries shall be organized on a profit sharing basis," ${ }^{60}$ we can only suggest that the Nazi message was flexible and they did or could not deny sectors of the business community large profits.

Schnitzler and other German business leaders in the Third Reich would have been in accord with the following statement made in 1981 by Konosuke Matsushita, the founder of one of the world's top fifty companies. "A business should quickly stand on its own, based on the service it provides a society. Profits should not be a reflection of corporate greed but a vote of confidence from society that what is offered by the firm is valued. When a business fails to make profits it should die --- it is a waste of the resources of society."61 During World War II, leadership in multinational GermanAmerican businesses, such as I.G. Farben, served the German state better than their American colleagues served the United States, but this will be more fully discussed later.

I.G. Farben was an integral part of the German power structure, and was connected to an even greater business community. It has been correctly argued that I.G. Farben would probably have not existed without the capital supplied by Wall Street investors, but an indictment against Wall Street is not the focus of this research. In 1933, the immediate goal of Farben and other German businesses was to repair and expand the economy. Financial contributions from industry solidified the partnership between the Hitler government and certain business organizations. Farben executives also financed the National Socialist Government, but with the exception of a few elites

60 H. Lubasz, Fascism: Three Major Regimes (New York, 1973), p. 78

61 Neil Chesanow, The World-Class Executive (New York, 1985), p. 23 
including Carl Duisberg, did so hesitatingly. In Germany, as in other capitalist countries, big business has always attempted to secure a market position through accommodation with those in formal positions of power.

This position was enhanced through a gratifying relationship with government. The creation of the giant I.G. Farben chemicals trust by Carl Bosch and Carl Duisberg in 1925 had been a result of proposals initiated as early as 1904 . The senior executive at Bayer, Carl Duisberg, called for a nationwide merger of the producers of organic chemicals, shortly before Fritz Thyssen would unsuccessfully attempt the same proposal to organize a national steel trust. In 1916, the "little IG," the Interessengemeinschaft der deutschen Teerfarbenfabriken ( Community of Interest of the German Dye-Works) combined in a single-industry merger. After the post-war inflation period, and stabilization of the German Mark in 1924, senior executives of member firms decided that a more centralized effort would be needed if they were to build up their organizational capabilities in Germany and regain their pre-war markets abroad.

In October of 1925, all the members of the supervisory boards and Vorstaende (managing boards) signed a merger agreement which established a "big I.G." which consisted of "four regional Operating (Plant) Communities or Departments (the terms Betriebsabteilungen and Betriebsgemeinschaften were used interchangeably) and five Sales Communities." 62 By the terms of this agreement, each of the four Betriebsabteilungen was located in a different geographical area of Germany (Middle Germany, Upper, Lower, and Middle Rhine), but each of them came under the supervision of a central office. Later, a fifth Operating Community would be established with the AGFA headquarters in Berlin. In this way, internal competition would promote 
overall efficiency in a near monopoly, with Sales Communities in the following areas: "(1) nitrogen, (2) dyes and other dye by-products, (3) inorganic chemicals and inorganic intermediates, (4) pharmaceuticals and veterinary products, and (5) photographic products." 63

While there was little need to replace outmoded skills and equipment in the chemical industry for the next several years, I.G. Farben entered a phase of limited rationalization and restructuring. There were to be no massive lay-offs or laboratory closings. Duisberg, for example, did cut the number of dyes produced at the Leverkusenfabrik of Bayer, but general policy was to make no radical changes on existing conditions. Relatively minor restructuring did take place, such as at the headquarters of the Middle Rhine Community. Hoechst took over the production of all chemicals made from acetylene, a highly flammable explosive gas, but in general, major laboratories continued to concentrate on much of the same product areas as they had before the merger, and indeed, since their beginnings in the late nineteenth century.

Sales forces in the I.G. moved toward immediate consolidation after 1926, resulting in a 50\% cut of the major sales agencies. At the same time, I.G. Farben's main products continued to be marketed from the same offices as they had been before 1925 . Due to the restructuring and rationalization, policy and operating decisions could be made more quickly, and senior managers of this large merger "in the consolidation of sales, as of production,.... were careful to build on the highly developed organizational capabilities of the constituent enterprises. "64

63 Ibid., p. 569

64 Ibid., p. 572 
Although I.G. Farben's dominance did not extend to all fields of the German chemical industry, as an export-driven industry production in its diverse markets and direct consumer sales compelled the cartel to generally support doctrines of economic liberalism. "Carl Duisberg and Carl Bosch, the two most prominent representatives of the firm until the mid-1930s, advocated free trade and limited state intervention in the economy. At the same time, neither the industry nor the firm was averse to accepting government subsidies for projects (such as synthetic nitrogen) that permitted Germany temporarily to overcome its poor resource base." 65 In 1928 , just before the depression, I.G. Farben's profits in the nitrogen business were estimated at 330 million Reichsmarks. "By mid-1932, I.G. anticipated losses of about thirty-three million Reichsmarks in the nitrogen business alone." 66

After the onset of the depression, I.G. Farben sold at a loss to some countries, but, "Duisberg, the foremost spokesman for I.G.'s dyes and pharmaceutical branches, concluded that the firm's 'attention must return primarily to the internal market, which will always remain the backbone of our economy." ${ }^{67}$ Determined to prevent a renewed collapse of international trade, I.G. Farben had, on the whole, still maintained "the twin pillars of traditional economic liberalism; free trade abroad and free enterprise at home," 68 even when faced with sacrificing profits in some markets. "This is also why the combine never split into two factions, one domestic-oriented and sympathetic to the Nazis and one export-oriented and hostile to the Hitler party"69

65 Stokes, Divide and Prosper, p. 13

66 Peter Hayes, Industry and Ideology (New York, 1987), p. 35

67 Ibid., p. 44

68 Ibid.

69 Ibid., p. 46 
According to Hayes, I.G. Farben's leaders held a common view that their corporation's fortunes depended upon the stabilization of Germany's currency and "on the restoration of German unity and power; that, in turn demanded patience and conciliation. ${ }^{70}$ It was believed that their policy of patience and conciliation would help "generate the profits that powered the product cycles; the goal of corporate political activity was to retain an optimal share of those profits." ${ }^{71}$ During this period, Duisberg and Bosch worked together for autarky and to strengthen primacy within the world market, in particular, with the United States.

Dr. Carl Duisberg (1861-1935) and Dr. Carl Bosch (1874-1940), the co-founders of I.G. Farben, were fundamentally of different temperaments. Duisburg's son, Curt (1898-1986) once wrote about his father and Bosch;

Carl Duisberg (war) ein tempermentgeladener, organisatorisch sehr exakt denkender und sozialpolitisch besonders engagierter Unternehmer, Carl Bosch, Wissenschaftler und Techniker, ein Genie mit allen Vorzuegen und Schwaechen eines solchen...Dies waren Gegensaetze, die hart aufeinanderprallten und die, so moechte ich sagen, in einer gewissen Hass-Liebe miteinander verbunden waren, die sich gegenseitig achteten, wobei der eine dem anderen half, wo er nur konnte. ${ }^{72}$

Before he became the first Chief Director of IG Farben, Duisberg had been known as the "Begruender und Fuehrer der chemischen Grossindustrie in Deutschland"73 Creating an industry in the 1860 s that was rural in origin, the young Duisberg supplied

70 Ibid., p. 48
71

72 Otto Koehler, ...und heute die ganze Welt: Die Geschichte der IG-Farben und ihrer Vaeter (Hamburg, 1986), p. 169

73 H.J.F. Flechtner, Carl Duisherg (Duesseldorf, 1981), p. 6 


\section{Page 45}

textiles and dyes to weavers and peasants, fertilizers to farmers, and medicines to druggists. By the end of the nineteenth century, he had combined several large German chemical firms to protect joint interests in the export trade.

Bosch, inventor of the Bosch magnet, was also interested in the nitrates that were a necessary ingredient in the manufacture of explosives. He had worked with Fritz Haber, in 1913, who invented a process for obtaining nitrogen from the air by combining it with hydrogen. This fixation of nitrogen process produced nitrates which are essential for fertilizers and explosives. It was one of the company's most important achievements in finding substitutes for critical raw materials which Germany lacked. Without the discovery of this process, Germany might have lost World War I within a few months, since up to this point, the Germans had to import nitrates, the essential ingredient for manufacturing explosives, from Chile. Bosch and I.G. chemists had also worked on discovering a less time-consuming way to make synthetic oils by using hydrogenation, a procedure developed by Friedrich Bergius, which converted coal into lubricating oils and petroleum for cars, airplanes, and tanks. Though synthetic oil was produced in quantity by I.G. Farben, "it was impossible to market: the synthetic material was six times more expensive than natural oil." 74

In July, 1932, it became apparent that the National Socialists, who had become the largest party in the Reichstag, had emerged as serious contenders to govern Germany. Carl Bosch, who at this time was I.G. Farben's chairman of the managing board, wanted to be certain that the National Socialists would maintain the late-Weimar government's policy of increasing import duties on oil, ${ }^{75}$ particularly since the company's officials had

\footnotetext{
74 Richard Overy, Why the Allies Won (New York, 1996), p. 230

75 see Stokes, Divide and Prosper, p.24
} 
been harassed by the National Socialist hierarchy for employing Jews. It was in Farben's interest to keep imported oil prices high in order for the corporation to receive some returns for their extensive investments in producing synthetic fuel. Newly discovered reserves in Texas and Oklahoma had saturated the petroleum market during the late 1920s. Bosch sent Duisberg's press secretary, Heinrich Gattineau along with the technical director of the Leuna plant, Heinrich Buetefisch, who was also an authority on synthetic oil production, to discuss the situation with Hitler. At this point, Bosch did not want to go to Munich himself, but preferred to send Buetefisch with a "promising young I.G. employee with good Nazi connections." ${ }^{76}$ Later, Gattineau recalled a meeting that turned out to be valuable:

Auf der langen Bahnfahrt nach Muenchen habe ich im Gespraech mit Buetefisch mehr ueber die IG, inbesondere ueber die neuen Verfahren, gelernt als in meiner bisherigen Zugehoerigkeit. Das Gespraech mit Hitler haben wir, soweit uns dies moeglich war, vorbereitet. Wir beide erhoffen uns nicht allzuviel davon; denn die Nationalsozialisten hatten wir bisher nur als Choaten und Gegner kennengelernt. ${ }^{77}$

Gattineau, who would later become chief of the political-economy department of I.G. Farben's Berlin Northwest 7 office, "... had been the student of one of Hitler's favorite intellectuals, Karl Haushofer, the Nazi geopolitician. In fact Gattineau had written his doctoral dissertation, 'The Significance of the Urbanization of Australia in the Future of the White Race,' under Haushofer's direction." 78 According to Louis Snyder, Haushofer had already "won the reputation as the man behind Hitler. The Fuehrer would

\footnotetext{
76 Borkin, p. 54

77 Koehler, p. 211 cited from Heinrich Gattineau, Durch die Klippen des 20. Jahrhunderts (Stuttgart, 1983), p. 18

78 cited in Turner, pp 248-9 by Hayes, p. 67
} 
use the political aspects of Haushofer's geopolitics (expansion and Lebensraum) as a rationalization for national expansion." ${ }^{79}$ Haushofer was also the teacher and friend of Rudolf Hess. Eventually, it would be Gattineau, via Haushofer and Hess, who would arrange the meeting between the I.G. officials and the Fuehrer. Although Haushofer by no means had the power of a Goering or a Himmler, his intellectual credibility and his high-level contacts in both political and business circles made him quite influential.

There is some question regarding the date of the first meeting between Hitler and I.G. officials, since there was apparently no written record kept of when the meeting occurred. Joseph Borkin, who was a member of the prosecution staff at the trial of I.G. Farben leaders at Nuremberg, concluded that the meeting was set "for early November before the election." [November 6, 1932] ${ }^{80}$ Peter Hayes concurs with Henry Ashby Turner's German Big Business and the Rise of Hitler, who places the session in June of $1932{ }^{81}$ Otto Koehler also cites the German translation of Turner's work, Die Grossunternehmer und der Aufsteig Hitlers:

Dass das Treffen mit Hitler im Juni stattfand, wie es in der Festschrift heisst, bestreitet auch Buetefisch nicht. Gattineau aber, der sich auch bei anderer Gelegenheit gern mal im Datum irrt, nennt mal den Herbst und mal das Ende 1932. Und wenn, wie er behauptet, die Angriffe von NSBlaettern auf die I.G. die alleinige Ursache des Treffens gewesen sein sollen, warum hatte man dann mit der Beschwerde bis zum Herbst gewartet? Der letzte bekannt gewordene NS-Artikel gegen die I.G. stammt vom Maerz 1932. ${ }^{82}$

79 Snyder, p. 140

80 Borkin, p. 55

81 Hayes, p. 67

82 Koehler, p. 213 
Die Konsumenten sind die linke Hand des gesellschaftlichen Organismus, die Produzenten sind die rechte Hand. ${ }^{83}$ (Erich Kaestner)

Before the significant meeting of Gattineau and Buetefisch with Hitler, I.G. Farben had been targeted by National Socialists as an "instrument of international finance capital dominated by such well-known Jews as Max M. Warburg, Arthur von Weinberg, Alfred Merton, Ernst von Simson, Otto von Mendelsohn-Bartholdy, and Kurt Oppenheim. I.G. was [also] cartooned as 'Isadore G. Farber,' a grotesque caricature of Shylock, and I.G. 'Moloch' an ugly reference to the Canaanite god to whom children were sacrificed." 84 By the time the meeting ended, I.G. Farben was not only assured that the company could depend on Hitler's sympathy; Hitler also "outlined a program under which he planned to make Germany self-sufficient in oil with the help of I.G.

Farbenindustrie. ${ }^{185}$

While the National Socialists lost thirty-four seats in the Reichstag in the November sixth election, the Communists had gained eleven. Consequently, elites by "their opposition to parliamentary democracy and preference for an authoritarian system, ... accelerated the break-up of the Weimar Republic and played into the hands of the dictatorship."86 As mentioned earlier, executives like Bosch believed there was no reasoning with the Communists and feared their potential alliance with the Social Democrats, but Hitler appeared a sensible man with whom industrialists and financiers could reason.

\footnotetext{
83 Kaestner, p. 71

84 Borkin, p. 54

85 Ibid.,. 55

86 Kolb, p. 193
} 
Page 49

Many powerful business figures supported Hitler's Party after the November election; Krupp, Thyssen, Siemens and other elites. Other business groups which contributed funds to the NSDAP included the National Chamber of Commerce, the National Federal German Employers' Association, the National Federation of German Industry, and the Junker Herrenklub. Nevertheless I.G. Farben, Germany's largest corporation, did not finance Hitler until after Hindenberg appointed Hitler chancellor in January 1933. If Duisberg, who was Chairman of the Aufsichtsrat (1925-1935) had been in Bosch's position of leadership as Chairman of the Vorstand (1925-1935), ${ }^{87}$ it is doubtful whether I.G. Farben would have waited until February 20,1933 to pledge "four hundred thousand marks, by far the largest single donation." 88

Borkin's figures are extremely conservative. In his Wall Street and the Rise of Hitler, Antony Sutton lists the financial contributions by L.G. Farben to Hitler and deposited at the Hjalmar Schacht account at Delbrueck Schickler Bank between February 23 and March 13, 1933 as $\$ 400,000 .{ }^{89}$ On the other hand, The New York Times reported the following during the trials at Nuremberg:

American prosecutors confronted I.G. Farben directors...with their own records showing that they had contributed $\$ 12,000,000$ to the Nazis from 1933 to $1934 \ldots$ The record of Farben aid to the Nazi Party started with a contribution of $12,693,089$ marks (about $\$ 4,500,000$ then) to the Adolf Hitler Fund in 1933. The statement of one of the defendants, Georg von Schnitzler, was offered showing that Farben gave $\$ 300,000$ to Rudolf

87 "Membership on the supervisory board gives the employees a strong voice in overall company policy ...but does not involve them in detailed management decisions." See W.R. Smyser, The German Economy (New York, 1993), pp. 81-2

88 Borkin, p. 56

89 Antony C. Sutton, Wall Street and the Rise of Hitler (Seal Beach, California, 1976), p. 110 loc. cit. 
Hess, then Deputy Fuehrer, three days before the crucial March 5 elections of 1933 when the Nazis swept into power. ${ }^{90}$

According to Borkin, Bosch had directed Schnitzler to pledge the 400,000 marks on February 20,1933 too, but there is no mention of Hess at this time. Carl Bosch opposed anti-Semitism on both personal and professional grounds, and several Jews were among his closest colleagues, including Haber and "his secretary for the preceding fifteen years, Ernst Schwarz, the son of a rabbi." 11

Bosch and Hitler had only autarky and the welfare of I.G. Farben in common. When they did eventually meet shortly after the Reichstag election of 1933, Bosch "moved to the subject that his associates at I. G. had urged him to avoid. He warned Hitler that if Jewish scientists were forced to leave the country, both physics and chemistry would be set back one hundred years in Germany."92 After this meeting, Farben associates managed to keep the two men apart, but Bosch continued to work against the expulsion of Jewish scientists like Fritz Haber from German business, and later from Germany itself.

Although Hitler argued in the mid 1920s against the ascendancy of joint stock companies like I. G. Farben and their negative impact on smaller enterprises as a "sign of economic decay," 93 I.G. Farben was receiving "a state subsidy as early as December 1933 to develop synthetic fuels at its Leuna plant."94 The National Socialist Government signed a deal with I.G. Farben: "the state promised to subsidize synthetic oil if the

90 The New York Times, September 3, 1947, p.2. [an unsigned news story]

91 Hayes, p. 92

92 Borkin, p. 57

93 Adolf Hitler, Mein Kampf, trans from the German by James Murphy (Los Angeles, 1981), p. 256

94 Marsh, p. 140 


\section{Page 51}

company committed itself to a four-year project."95 By 1943, Germany would produce over seven million tons, three quarters of all the fuel she used. ${ }^{96}$

Despite his enthusiastic pledges to solve unemployment and other economic problems, it is doubtful that Hitler had a set economic plan when he was sworn in as German Chancellor. Shortly after he came to power, Hitler did away with the laws that were designed to limit the cartels' strength during the Weimar Republic and made cartels compulsory for the entire economy. The state now had the power to force outsiders into existing cartels and to form new ones. Cartelization strengthened monopolies, and at the same time, placed no limit on corporate earnings, though dividend earnings were limited to six per cent. The Third Reich's eventual control of "important segments of economic life -- consumption, investment, and labor... ensured that the armaments industries would expand to support Hitler's foreign policy." 97 Representatives of the cartels acted as efficiently within the Nazi bureaucracy as they had in their own organizations." 98

Based upon a policy of rearmament, Hitler's "Four Year Plan" for national economic self-sufficiency was not devised until the summer of 1936 . The proclamation was read by the Bavarian Minister for Education and Culture, Adolf Wagner (1890-1944) for Hitler at the annual party rally at Nuremberg. "I [Hitler] today present the following as the new Four-Year Plan. In four years, Germany must be wholly independent of foreign areas in those materials which can be produced in any way through German ability, through our chemical and machine industry, as well as through our mining industry. The rebuilding of this great German raw material industry will serve to give

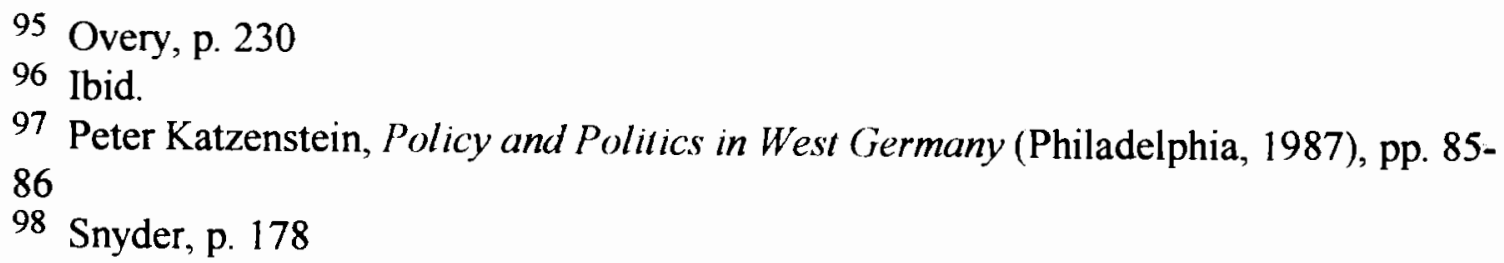


employment to the masses. The implementation of the plan will take place with National Socialist energy and vigor. But in addition, Germany cannot relinquish the solution of its colonial demands. The right of the German people to live is surely as great as that of other nations..."99

The implementation of this plan was entrusted to Hermann Goering. In order to minimize dependence on imported raw materials, a major program to manufacture synthetic materials got under way. Coal was the one raw material which Germany had in abundance, and it was used to manufacture oil and rubber, two necessary materials for war. By 1938, Germany's industrial production would more than double the 1932 output. War preparation became a dominant fact of German economic life, and Goering would need to "utilize a labor force on behalf of the plan, justifying the practice on the ground that the German people were fighting for their very existence." 100 The Nazi methods of "utilization" would become most obscene during the next World War. It is important to also note that I.G. Farben's Carl Krauch proposed a "first" four-year plan for the expansion of Germany's production of "domestic" motor fuel as early as September 15 , 1933. ${ }^{101}$ It was in the interest of I.G. Farben executives to increase government investments on production of synthetic fuels, rubber, and other materials, even though it could be up to six times more expensive to produce these goods than the real product.

On the surface, this economic planning document presented the thesis that Germany could become self-sufficient in raw materials by investing in the synthetic goods industry. Although Hitler did not expect complete self-sufficiency within the prescribed four-year period, decreased dependency on foreign resources could be

\footnotetext{
99 Ibid., p. 96

100 Ibid.

101 Borkin, p. 59 loc. cit.
} 
attained, and the German economy would be prepared for war by 1940 or 1941. "I thus set the following tasks: (1) The German army must be operational within four years; and (2) the German economy must be fit for war within four years." ${ }^{102}$ At the same time, the German people and workers were being particularly inundated by terror propaganda from their own capitalists. Germans believed that if their country had to rely on foreign resources, the "inevitable" war would destroy Germany once and for all. In fact, the origins of 1936 Four-Year Plan reveal the nature of an alliance between industrialists and the Nazi leaders. "The document was written in toto by I.G. Farben aides who were supplied to Goering's office for this purpose. The massive propaganda campaign about autarky was merely a device to justify government credits to I.G. Farben for the synthetic goods industries - credits that Schacht had been denying." 103

The Reich Minister of Economics Hjalmar Schlacht (1934-37) would eventually be forced to resign from his post due to his opposition to this inflationary process of rearmament. At the time the Reich institutionalized the Four-Year-Plan, export prices were unfavorable, and Germany did not have sufficient gold to pay for the increasing amounts of raw materials needed from abroad. The already over-inflated Reichsmark, the result of artificial pegging by U.S.-British bankers, had made "German exports fifteen to twenty-five per cent more expensive than those of Britain." ${ }^{104}$ Rather than a devaluation of the Mark to combat inflation, the Reich government wanted tight foreign exchange controls "through emphasis upon foreign trade with areas most likely to remain reliable import sources in times of conflict, such as Scandinavia, the Balkans, and the

102 Louis L. Snyder, Hitler's Third Reich, (Chicago, 1988), p. 232

103 Costas Axios, "Final Solution: The Schachtian Economy of the Third Reich," The Campaigner (March, 1975), 27

104 Ibid., p. 26 


\section{Page 54}

Near East." 105 Insulation from cyclical trade movements and the creation of a closed economy made "good business sense."

Until 1936, Schacht had "eased big business out of the direct form of Party control that had been envisaged by the Nazi populists and Mittelstand ideologists." 106 After the initiation of the Four-Year-Plan, another layer of administration and representatives of private industry was imposed on the German economy, as firms competed against one another for lucrative government contracts. There was no forceful leadership to overcome the confusions of authority between the ministries responsible for armaments and the military. Goering, who was up to this point the key political figure of the Four-Year Plan, was idle, and Walter Funk, who replaced Schacht as minister of Economics and in 1939, as president of the Reichsbank, was obligated to Goering and provided insignificant leadership. As one industrialist remarked, "business is not in the least bit concerned whether it is ruled by a tin helmet or a top hat, but it is time that it was decided which headgear would be worn." 107

Although it is disputed whether I.G. Farben or Hitler initiated the idea of Schacht's removal as Economics Minister, it remains a fact that the aggressive manufacturer of synthetic substitute products wanted him removed because of his opposition to an all-out conversion to autarky. Some East German analyses claim that Schacht, who called for a "slowdown in arms production and an expansion of exports to redress the balance of payments... was acting ... also at the behest of American 'finance capitalism' to which he was claimed to be closely linked and which allegedly hoped to

105 Hardach, p. 72

106 Gruenberger, p. 228

107 Martin Kitchen, Nazi Germany at War (London, 1995), p. 42 


\section{Page 55}

retain, with his help, access to the German market." ${ }^{108}$ One much-criticized agreement between Standard Oil and I.G. Farben left the United States with no synthetic rubber industry at the outbreak of World War II. The war was more than half over before the synthetic rubber problem was fixed.

I.G. Farben's development of synthetic oil and rubber, which had not been profitable in 1933, became a profitable venture. Carl Krauch, who had been instrumental in initiating government commitment to the development of synthetic fuels and rubber, headed the operation which "received an almost unbelievable 72.2 per cent of the total capital invested by the Four-Year Plan between 1936 and 1939." 109 Government subventions prompted the combine to build new factories and to sign "additional marketing and product development agreements with Standard Oil in the United States and Shell Oil in Great Britain."110

After 1933, capitalism was administered by the National Socialists, who disguised their acceptance of it by channeling ever more of its production into war material. Private property in the means of production remained, but the right to control privately owned property was severely limited by state regulation. Nevertheless, support for capitalism, private property, inherited wealth, and elites enjoying the fruits of these does not necessarily imply submission to uncontrolled market forces. Governments, including the National Socialists, have frequently pursued their objectives through subsidies to private enterprise, the regulation of markets and heavy state consumption through debt - in this case for rearmament. Franz Neumann wrote in 1942 that "the German economy today has two broad and striking characteristics. It is a monopolistic economy and a command

108 Dorpalen, p. 412

109 Alan F. Wilt, Nazi Germany (Arlington Heights, Illinois, 1994), p. 57

110 Ibid. 
economy. It is a private capitalistic economy, regimented by the totalitarian state. We suggest as a name best to describe it, 'Totalitarian Monopoly Capitalism'... the automatism of free capitalism, precarious even under a democratic monopoly capitalism, has been severely restricted. But capitalism remains." 111 Not unlike other capitalist machines, Hitler's totalitarian state maintained cohesion through patronage and "kickbacks."

At the same time, the German worker did not fare as well as his employers under National Socialism. Although wages and salaries increased, "the average weekly labor time increased from 41.5 hours in 1932 to nearly 47 hours in 1938 . Thus the growth of wages is to be seen as the result of rising working hours. Wages and salaries as a proportion of national income fell from sixty-four per cent in 1932 to fifty-seven per cent in $1938^{\prime \prime} 12$ Both the National Socialists and the monopolistic business interests had no illusions about the underlying hostility of the working class, and increased its exploitation. But it was precisely this class, the workers, that significantly extended the life span of the Third Reich. The socio-economic experiment of the National Socialist regime would survive until 1945; it would be different for the corporations like I.G. Farben who gave life to this experiment.

\section{IV.E. Aryanization and the Changing Character of I.G. Farben}

The most important plank in the National Socialist program is to abolish the liberal idea of the individual and the Marxist idea of humanity and to substitute for them the folk community rooted in the soil and held together

111 Franz Neumann, Behemouth--The Structure and Practice of National Socialism (New York, 1944), pp. 261 and 361

112 John Milgate Eatwell, editor, Problems in a Planned Economy (New York, 1990), p.106 


\section{Page 57}

by the bond of common blood. This sounds simple, but it involves a principle which has great consequences. ${ }^{113}$ (Voelkischer Beobachter, January 31,1937 )

Let the facts speak. The department stores - which before Hitler's coming to power were the chief objective of the Nazi's anti-Jewish campaign have indeed changed hands. The Jews flew out, but no shopkeepers flew in. ${ }^{114}$ (Hans Behrend)

No modern society and or the state it encompasses can exist and prosper without myths of some kind. Friedrich Nietzsche, who would probably have been offended by National Socialist myths, argued that "myths are indispensable to the ecology and survival of a community, for they form the horizon of its imagination, the measure of its ethical standards, and the scale of its moral judgments." 115 The attempts to heroicize the German national identity, folk soul or Volksgemeinschaft in a "post-heroic" era of Germany today is humorous and embarrassing to those who do not deplore its absence. Prior to the end of the Third Reich, the national myths which conferred a sense of mission based upon resentment, ignorance, and violence found support in the bigbusiness sector of the Third Reich's economy. In their "struggle" for profitable reorganization of German industry, corporate leaders gradually adopted the widespread policy to eliminate Jews from all business sectors.

Aryanization expedited the shake-up of the German economy. "The elimination of Jewish ownership halved the number of enterprises in certain branches of the textile and clothing industries, while Aryanizers active in machine building, flour milling, and the shoe and leather trade were actually the first pioneers of larger than middle-sized

113 Snyder, Hitler's Third Reich, p. 247

114 Hans Behrend, The Real Rulers of Germany, trans from the German by Charles Ashleigh (London, 1939), p. 107

115 Stern, p. 300 
enterprises in the history of these industries." 116 In the chemical industries, I.G. Farben, which had been a target of National Socialist propaganda and harassment during the early 1930s, supported Hitler's economic strategy up to the point where it would not undermine its own ideas of stability. With the exception of Carl Bosch, large scale enterprise leaders appeared to endorse the National Socialist strategy of eliminating non-Germans from corporate and public life. Gleichschaltung (coordination) and the Aryanization of all sectors of German life into a National Socialist machine presented a threat to the "monopoly capitalism" of business, but also provided them with opportunities for profit and expansion.

I.G. Farben lost twenty nine members of their supervisory board and thirty one members of their managing board between 1930 and 1932. ${ }^{117}$ Carl Bosch protested the forced dismissal of the Jews and warned Hitler personally that "...we will work for a century without physics or chemistry." 18 As the older elites were dying off or were pensioned, a new generation sought favor with the NSDAP. "The Nazis and the activities they sponsored received some 4.5 million reichsmarks from I.G. Farben in 1933. This was merely the first installment of grants totaling about forty million marks by 1945 and nearly equaling all of I.G.'s other charitable contributions combined." 119 Within a few years after Hitler's rise to power, I.G. Farben was interdependent with National Socialism.

In 1937, following the introduction of Four-Year-Plan subsidies to I.G. Farben, membership in the NSDAP was re-opened, "and almost all the members of the I.G.

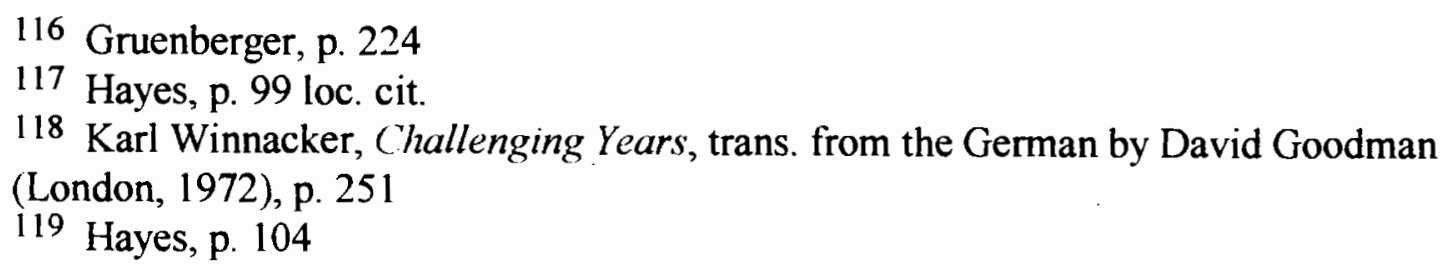


managing board who did not already belong now joined up, including Carl Krauch, Fritz ter Meer, Georg von Schnitzler, Max Ilgner, Otto Ambros, Friedrich Jaehne, Christian Schneider, Karl Wurster, Carl Lautenschlaeger, and Ernst Buergin. (Hermann Schmitz, Heinrich Hoerlein, Wilhelm Mann, Fritz Gajewski, and Hans Kuehne already were members.)" 120 Buetefisch is not mentioned here, even though, as a member of I.G.'s Vorstand, he ..."became a regular participant in Himmler's 'Circle of Friends." 121

Aryanization at I.G. Farben had begun shortly after Farben officials had first met with Hitler in 1933, but in 1937, "all Jewish officials of the I.G. ... were removed including a third of the supervisory board." 122 Bosch was no longer at the head of Farben, but as a relatively inactive honorary chairman of the supervisory board, Bosch continued to speak his mind. He believed that war would be impractical for German industry, and remained, until his death, "the only German industrial leader who did not fear to speak his mind."123 He was clearly "above the system" of intimidation by the National Socialists. Nevertheless, it is apparent that most industrial leaders at I.G. Farben were "speaking their minds" in support of the National Socialist government. At this time, I.G. Farben's Carl Krauch was gaining special attention in the Third Reich. Krauch was the head of the I.G. division that produced almost all of Germany's nitric acid.

Krauch, who, surprisingly, does not have a separate entry in Snyder's Encyclopedia of the Third Reich, detailed an enthusiastic program entailing enormous expansion of I.G. Farben production levels of nitric acid, in order to meet gunpowder and

\footnotetext{
120 Borkin, p. 72

121 Hayes, p. 337

122 Borkin, p. 72

123 Ibid.
} 
explosives requirements in the "next" war. Goering and the NSDAP hierarchy bought Krauch's plan which "called for greatly accelerated expansion in synthetic oil and rubber and light metals as well as explosives, gunpowder, and poison gas." 124

Krauch's resume included the following: "chairman of Farben's supervisory board of directors (Aufsichtsrat); First head of the Vermittlungsstelle Wehrmacht (Farben's army liaison office); General Plenipotentiary for Special Questions of Chemical Production on Goering's staff; Eminent synthetic nitrogen and fuel scientist; Director of the Ford Motor Company in Germany." 125 Besides being an expert on atomic energy, Krauch had not divested himself as a professor at the University of Heidelberg, a university with close relationship with little and big I.G. during the Bosch and Duisberg era. A NSDAP member known as the Munitionsdiktator, who "verkoerpert die Einheit von Partei, Staat, und Interessengemeinschaft," 126 Krauch was, in the late 1930's, perhaps the most powerful industrialist in the Third Reich, to the extent that he, Goering's friend, had frequent audiences with Hitler and was the only person from I. G. Farben that Carl Bosch would see.

Up until the end of his life, Bosch believed that "Hitler's lunacy would result in the destruction of Germany and the end of I.G. which for him were equal disasters." 127 At the time of Bosch's death in 1940, Professor Krauch was elected to succeed Bosch as chairman of the supervisory board, giving up all managerial duties to devote more time to the plenipotentiary of chemical production on Goering's staff. Hermann Schmitz would assume the position he had already held in name, Chairman of the Vorstand. Schmitz

\footnotetext{
124 Ibid., p. 74

125 DuBois, p. 365

126 Koehler, p. 269

127 Borkin, p. 99
} 
also held titles of Director of the Bank of International Settlements, Chairman of the board of Directors of American I.G. Chemical Corporation, New York, and Chairman of I.G. Chemie, Basel, Switzerland. Schmitz, who had belonged to the inner circles of the business community since the early days of the Interessengemeinschaft, was uncle to another member of the Vorstand (managing directors), Max Ilgner.

Max Ilgner was a descendant of a family of Prussian officers. Before he devoted himself to business administration studies in the early 1920s, he had "joined a Freikorps unit after the revolution had frustrated his own plans for a military career."128 In 1929, llgner succeeded his uncle Hermann Schmitz as chief of the Berlin Northwest Seven office, directing I.G. Farben intelligence, espionage, and propaganda. Shortly thereafter, Ilgner went to the United States to promote Farben's interests in America, under I.G. Chemical Corporation. Within two years, "IGCC's board of directors included Walter Teagle, president of Standard Oil, Charles Mitchell, President of National City Bank of New York, and Edsel Ford."129 I.G. Chemical Corporation would be later renamed General Aniline and Film, to avoid "embarrassment" of American stockholder investment in an I.G. firm.

In 1931, Ilgner, returned to New York to form 'Chemnyo' to handle the patents for I.G. Farben's United States firms. Chemnyo's directors, sons of I.G. founder, Carl Duisberg and Walter von Rath became American citizens to enhance business operations abroad, while Max Ilgner appointed his brother Rudolph, also a United States citizen, to manage both his patent office in Berlin and Chemnyo. In 1937, Max and Rudolf transferred the patent unit of American I.G. to Chemnyo. The American I.G. connection

128 Henry Ashby Turner, Jr., German Big Business and the Rise of Hitler (New York, 1985), p. 261

129 Josiah E. DuBois, The Devil's Chemists (Boston, 1952), p. 24 
brought together James Forrestal, future Secretary of the Navy, and former U.S. Attorney General Homer S. Cummings, both of whom were members of the board of Standard Oil. At this point, links between I.G. Farben and Wall Street became multifarious. Joseph Borkin and Charles Higham discuss the relationship in depth.

\section{IV.F. The Role of I.G. Farben in Slave Labor and Genocide}

The people in the city [Auschwitz], the S.S. men, the camp inmates, foreign workers, all the camp knew it. All the civilian population knew it, they complained about the stench of the burning bodies. Even the IG Farben employees to whom I spoke, a lot of them would admit it. It would be utterly impossible not to know." 130 (Charles Joseph Coward, a British prisoner of war in his evidence in the post-war trial of I.G. Farben.)

The aim of German social and politicai policy "was to make secure and preserve the racial community (Volksmasse) and to enlarge it."131 Although the first concentration camp, Dachau, was erected in 1933 to deal with large numbers of political prisoners, I.G. Farben's direct involvement with concentration camp labor did not escalate until its directors had knowledge of the war with the Soviet Union.

Nevertheless, forced labor had been a prior option for businesses in the Third Reich. In order to "maintain and increase Germany's industrial mobilization known as 'military economy'... and to increase her war potential," 132 a company was formed by the SS to exploit the labor of concentration camp prisoners: Deutsche Erd- und Steinwerke GmbH (DEST, German Quarrying Company) From 1941 prisoners at Auschwitz were

\footnotetext{
130 Walter Laqueur, The Terrible Secret (New Brunswick, New Jersey, 1980), p. 23

131 Snyder, Encyclopedia of the Third Reich, p. 263

132 Otto Tolischus, "General 10-Hour Day Due." The New York Times, December 22, 1938, p. 13. [a signed news story]
} 
contracted from DEST and the SS by I.G. Farben for the production of synthetic rubber (Buna). Separate camps were erected in Poland for the exploitation of Jewish labor, and Jews arriving at Auschwitz (although not at other death camps such as Treblinka, Sobibor, Belzec, and Chelmo) were spared the gas chambers as long as they provided useful labor. ${ }^{133}$

The concentration camps were a notable and increasingly important asset to the German war effort. In coordination with the National Socialist government "who used the instruments of modernity to pursue their reactionary, anti-modern aims,"134 I.G. Farben and other Reich companies set up production facilities near poorer areas and concentration camps where labor was cheapest. Just like today's modern transnational executives, they focused their marketing efforts in countries where wages and prices were highest. Under the auspices of the Wirtschafts und Verwaltungshauptamt, prisoners, ethnic "undesirables," and foreign laborers were exploited by German industry. At the same time, the German industrial elites, at I.G. Farben and elsewhere, denied involvement with mass murdering of non-useful laborers. Auschwitz, which was a collaborative business venture between I.G. Farben, Krupp, and the SS, received Reich subsidies to build a large industrial park around it. There, the companies' personal departments sorted laborers on the railway platform to determine who would live and work and who would die. "Life expectancy of the Jewish slave laborer was three months in the factories and one month in the coal mines." 135

I.G. Farben's management style was less than "mean and lean," it was criminal.

133 see Simpson, pp. 96 and 290

134 Kitchen, p. 306

135 Axios, p. 34 


\section{Page 64}

The commandant of Auschwitz (and elsewhere), Rudolf Hoess reported the following at Nuremberg:

Seit 1934 hatte ich ...in der Verwaltung von Konzentrationslagern zu tun und tat Dienst in Dachau bis 1938; dann als Adjutant in Sachsenhausen von 1938 bis zum 1. Mai 1940, zu welcher Zeit ich zum Kommandanten von Auschwitz ernannt wurde. Ich befehligte Auschwitz bis zum 1 . Dezember 1943 und schaetze, dass mindestens 2500000 Opfer dort durch Vergasung und Verbrennen hingerichtet und ausgerottet wurden; mindestens eine weitere halbe Millionen starben durch Hunger und Krankheit, was eine Gesamtzahl von ungefaehr 3000000 Toten ausmacht. Diese Zahl stellt ungefaehr 70 oder 80 Prozent aller Personen dar, die als Gefangene nach Auschwitz geschickt wurden; die uebrigen wurden ausgesucht und fuer Sklavenarbeit in den Industrien des Konzentrationslagers verwendet. 136

Commandant Hoess, who in his testimony, portrayed himself as a perfectly normal man with outstanding professional ability, was himself executed at Auschwitz in 1947 by the Nuremberg courts. "To him the business of exterminating Jews was strictly an impersonal, mechanical system with the precision of modern industry. His work was to him hygienic and clinically clean...(and) his orders relieved him in his own mind of any personal responsibility." 137

At the same time, I.G. Farben's leaders "spoke openly of the gassings, (and) wielded them as an incentive to work harder." 138 By 1943, the top ranks of Farben officials understood procedures at Oswiecim (Auschwitz). Friedrich Jaehne, who would be later found guilty at Nuremberg of "plundering" and sentenced to one and a half years in prison for his role in "plant development" at Auschwitz, gathered enough information

136 Walther Hofer, editor, Der Nationalsozialismus Dokumente 1933-19+5 (Frankfurt am Main), p. 305

137 Snyder, Encyclopedia of the Third Reich, p. 167

138 Hayes, p. 364 


\section{Page 65}

"while traveling on a train to Auschwitz to ask his son, an engineer in the boiler house of the Buna plant, whether gassings were taking place. He answered that this was the rumor." 139 The "rumor" had also spread to the offices of other top Farben officials such as Schmitz, Ambros, von Schnitzler, terMeer, Struss, and Duerrfeld. Their professionalism insulated the corporate elites and their company from the obligation to make social or moral judgments. Farben leaders and Hoess were not required to evaluate their decisions as long as the government financed their special "competencies and responsibilities."

Corporate responsibility and professionalism has typically sought to benefit stockholders and internal leaders. In the Third Reich, a refusal to cooperate would be, at least, hazardous, but the degree of imperilment can be proportional to one's status in a society, and perhaps in relation to one's ingenuity. Nevertheless, in corporate leadership roles, there are more examples of Carl Duisberg, who..."feiert 1933 mit der SA sein 50jaehriges Betriebsjubilaeum" 140 than of Carl Bosch, who proclaimed Hitler's "lunacy" for leading Germany to war, and for destroying I.G. Farben in the process. At Nuremberg, Heinrich Buetefisch, member of IG Farben's board of directors of syntheticoil and explosive companies in Austria, Hungary, Romania, Yugoslavia, Poland, Czechoslovakia, and Russia stated the following: "...Ohne die IG-Farben, inbesondere die IG-Produktion auf den Gebieten des synthetischen Treibstoffs und des Magnesiums waere es fuer Deutschland ausgeschlossen gewesen, einer Krieg zu fuehren."141 Buetefisch was also a lieutenant colonel in the SS.

\footnotetext{
139 Ibid., p. 365

140 Koehler, p. 177

141 Ibid., p. 205
} 


\section{Page 66}

Peter Weiss's documentary drama Die Ermittlung provides insight into the murderous collaboration of professionals within the Third Reich. Even though Weiss based his play on the later 1963-1965 trial at Frankfurt of eighteen former staff members at the Auschwitz Concentration Camp, he shows how active and passive participation in the Third Reich was defensible because all Germans did nothing but their duty. Just like the defendants who worked as administrators at Auschwitz Concentration Camp, there was the stationmaster of the railroad which transported camp prisoners to their death. In the same manner, medical orderlies who would lead the prisoners to the crematorium, were only doing their best, it was their duty. Duty also took responsibility for activities of I.G. Farben's Vorstand and non-Vorstand managers during the Third Reich. Walter Duerrfeld, a non-Vorstand manager, was typical of professional ambition exemplified in I.G. Farben's operations.

Dr. Duerrfeld, who had been the chief engineer at the enormous nitrogen fixation plant at Leuna near Merseberg from 1932-1941, joined the National Socialist Party in 1937. In 1941, he accepted a career-enhancing opportunity with Farben to look for a site to erect a new plant located near raw materials and a labor supply. He chose Auschwitz, Poland. Duerrfeld was appointed to build this structure and to direct its operations. As director of the industrial sector, Duerrfeld was responsible for thousands of inmates who worked and died on the construction site and in I.G. Farben's mines. "When Duerrfeld was placed on trial in Nuremberg after the war, he told the tribunal that he had been the overseer of thirty thousand people, including employees and inmates, in a plant covering ten square miles. He couldn't be everywhere at once." 142 Although, the number of

142 Raul Hilberg, Perpetrators, Victims, Bystanders (New York, 1992), p. 31 


\section{Page 67}

'thirty thousand people' is extremely conservative, I.G. Farben made the most of their opportunity.

Despite the influx of putatively inferior foreign workers, Farben's sales income per worker in the core corporation was 580 marks higher in 1942 and 806 marks higher in 1943 than in 1939; expenditures for wages, insurance, and social services had fallen by 407 and 194 marks per head respectively. Thus, at the height of the war, the enterprise was making roughly 1,000 marks more per worker annually before deductions for general overhead than when the fighting began. ${ }^{143}$

At all upper levels of I.G. Farben's management team, personal responsibility for misuse, exploitation, and mass murdering was dismissed as management team's inability to know what was going on. Except for the Jews who were dismissed from the company, I.G. Farben had access to top professionals who, by the time the war began, were concerned "more about the quantity of output than the income per worker put on it." 144

...now that the formula for universal serfdom has been discovered...there exists no social property, no living possession, no human being who really has or is anything. ${ }^{145}$ (Moses Hess)

Since no central agency in the Third Reich had been delegated to deal with the elaborate enterprise of destruction during World War II, collaboration in the war effort and Endloesung of ethnic and labor problems in the Third Reich was furthered by participation of functionaries in establishment entities and organizations. The Reich Chancellery coordinated laws and decrees. The Interior Ministry defined the term Jew

\footnotetext{
143 Hayes, p. 344

144 Ibid., p. 345

145 Shlomo Avineri, Moses Hess (New York, 1985), p. 130
} 
and deprived non-Aryans of property. The churches supplied proof of Jewish decent, and the Education Ministry eliminated Jewish students, professors, and researchers. All ministries, chancelleries, and authorities in the Third Reich had a job to do. Each of them benefited by the acquisition of additional power and official authority, though some agencies, like the education ministry lost some of their students, professors, and researchers. At the same time, the Economics Ministry, which provided regulations for the acquisition of Jewish firms, represented financially profitable ventures for bank concerns and, firms such as I.G. Farben.

Reich banking concerns, the Dresdener Bank among others, were profit-making intermediaries in the takeover of Jewish firms. Many retailers, wholesalers, manufacturers, and construction industries acquired Jewish firms for nothing or less than their monetary worth. Later, forced labor of Jews, foreigners, and other outsiders, provided substantial business profits for corporate leaders. The elites of I.G. Farben had a dominant voice in obtaining bank appropriations, as well as supervising distribution of conquered assets.

After the invasion of Poland in 1939, I.G. Farben was as concerned in making long-term monetary investments in production, as well as in looting and exploiting every ounce of the conquered people and territories. "The influx of slaves for the German war economy had begun just three days after the Nazi invasion of Poland..... Within a few months the number of conscripted slaves amounted to over a million." 146 Many of these early conscripted "recruits" were Poles, who were left with the alternative of either starving to death or "voluntarily resettling in the Reich" 147 In order to pay for

146 Axios, p. 37

147 Ibid. 
construction materials and costs, I.G. Farben industrialists had typically borrowed from the German state, but Auschwitz presented odd opportunities for the directors at I.G. Farben.

With the selection of Otto Ambros and Heinrich Buetefisch as respective directors of the rubber installation and gasoline plant at Auschwitz, I.G. Farben's directors began to ascertain the possible financial rewards of Hitler's Drang nach Osten. The Soviet Union and Asia represented a potential new market for profitable exploitation, so the "directors voted to put up the funds to make I.G. Auschwitz a privately owned I.G. enterprise and to assume the entire risk. With almost no opposition, they committed more than $900,000,000$ Reichsmarks, over $250,000,000$ dollars, to the building of the single largest project in the I.G. system." ${ }^{148}$ There is some disagreement regarding total expenditures at I.G. Auschwitz, as the "investment" figures range as low as "700,000,000 Reichsmarks,... while construction work required 170 contractors." 149

Rather than accepting financial support from the Reich government, I.G. Farben leaders were willing to gamble their own capital because they believed that the Auschwitz project would also have boundless post-war potential. Adequate labor at Auschwitz, which would be arranged through government channels, was assured by Himmler and the SS. With the same mentality that "respectable" contemporary corporate leaders relocate their manufacturing bases to utilize the most profitable labor force, slave labor minimized costs and maximized profits for I.G. Farben.

For most slave laborers, housing was a wooden bunk in a concentration camp barrack and they had little clothing. A typical diet for slave laborers at the I.G. Farben

148 Borkin, p. 116

149 Richard L. Rubenstein, The Cunning of History (New York, 1975), p. 58 
was potato peel or turnip soup. This "Buna soup" diet fed to inmates at Auschwitz "resulted in an average weight loss for each individual of about six and a half to nine pounds a week.... After three months, they were either dead or so unfit for work that they were marked for release to the gas chambers at Birkenau." 150

In the early 1940s during the height of the Reich hegemony in Europe, directors and managers throughout I.G. Farben developed a plan to dominate European chemical trade. In order to maintain higher profits, Farben's corporate leaders were firmly embracing the economics of a sort of neomercantilism. The firm's role in the Reich's social order, "along with the trust's use of slave labor and its unwillingness to recognize, criticize, or stop the regime's mass murder program, exemplified Farben's gradual and fatal emulation of Nazi policy and practice."151 In any case, firms exist to make money, and during the Third Reich, I.G. Farben and its leaders made a lot of money, while it "occupied the chemical factories of competitors in countries overrun by German armies and/or forced them to sign contracts advantageous to the I.G.."152 The following table was compiled, and percentages calculated from Hermann Gross, 'Material zur Aufteilung der I.G. Farbenindustrie Aktiengesellschaft' (Kiel: Institute fuer Weltwirtschaft 1950), Tabelle la. ${ }^{153}$

\begin{tabular}{ccc}
\hline Year & $\begin{array}{c}\text { Net Profit } \\
\text { (million RM) }\end{array}$ & $\begin{array}{c}\text { Net Profit as } \\
\text { Percent of Turnover }\end{array}$ \\
\hline 1926 & 119.8 & 11.6 \\
1927 & 113.6 & 9.0 \\
1928 & 110.9 & 7.8
\end{tabular}

150 Borkin, p. 125

151 Stokes, Divide and Prosper, p. 31

152 Ibid., p. 27

153 Ibid., p. 26 loc. cit. 


\begin{tabular}{lcc} 
Year & $\begin{array}{c}\text { Net Profit } \\
\text { (million RM) }\end{array}$ & $\begin{array}{c}\text { Net Profit as } \\
\text { Percent of Turnover }\end{array}$ \\
\hline 1929 & 100.9 & 7.1 \\
1930 & 90.2 & 7.6 \\
1931 & 55.0 & 5.4 \\
1932 & 48.6 & 5.5 \\
1933 & 62.9 & 7.0 \\
1934 & 64.9 & 6.6 \\
1935 & 66.8 & 6.1 \\
1936 & 132.3 & 10.2 \\
1937 & 195.0 & 12.9 \\
1938 & 190.4 & 11.6 \\
1939 & 239.2 & 12.0 \\
1940 & 298.1 & 13.8 \\
1941 & 311.5 & 12.3 \\
1942 & 271.3 & 9.3 \\
1943 & 300.4 & 9.6 \\
1944 & 145.4 & 5.7 \\
\hline & &
\end{tabular}

(It is important to note that budgets for such expenditures as research increased in absolute terms, but did not in percent of turnover-the amount of business transacted during this time period)

During this period after 1940, in which I.G. Farben made extensive use of slave labor, concentration camp inmates, and prisoners of war, its directors "agreed to pay the SS one and a half to four marks a day for various classes of labor from Oswiecim (Auschwitz). The lowest rate was for children." 154 Typical blue collar workers received about fifty percent of white collar wages in the late 1930s. According to Wirtschaft und Statistik Nr.23/1938, the actual average amounts were 1,373 marks and 2,727 marks respectively. ${ }^{155}$ German laborers in 1942 averaged an hourly rate of fifty pfennigs an

154 The New York Times, May 4, 1947, p. 54. [an unsigned news story] 155 Gruenberger, p. 253 loc. cit. 
hour in Pomerania to 90 pfennigs an hour in Hamburg. The average sixty to seventy-two hours per work week by 1944 for priority arms industries was less than the I.G. Auschwitz's requirements. Of course, cheap labor was not the only force mitigating an expansion of I.G. Farben's profits; war was financially rewarding for Farben's corporate leaders.

In Hitler's Social Revolution, David Schoenbaum noted that I.G. Farben "made a home for itself in the Third Reich"156 Resident corporate executives at Auschwitz, Dr. and Frau Walter Duerrfeld, the head of I.G. Auschwitz, and Dr. and Frau Kurt Eisfeld, the head of I.G. Auschwitz's synthetic rubber division, were often invited to the home of commandant Rudolf Hoess for social gatherings. Dr. Fritz ter Meer, I.G. Farben's executive in charge of synthetic rubber and petro-chemical operations including at I.G. Auschwitz, was also seen to feel "at home" during his frequent visits to the camp and other I.G. plants. At Nuremberg, ter Meer did not

express any regret about I.G. Auschwitz after the war. When queried by a British officer, Major Edward Tilley, whether he regretted the experiments conducted upon concentration camp victims by I.G. Farben's pharmaceutical subsidiaries, such as Bayer, Dr. ter Meer is reported to have replied that "no harm" had been done to these $K Z$ (concentration camp) inmates as they would have been killed anyway. ${ }_{1} 57$

Dr. Otto Ambros, chief of the chemical-warfare committee of the Ministry of Armaments and War Production and production chief for Buna rubber and poison gasses, was also an informed member of I.G. Farben's Vorstand. Auschwitz commandant Hoess recollected upon his relationship with Ambros after the war:

156 David Schoenbaum, Hitler's Social Revolution (New York, 1967), p. 157

157 Rubinstein, p. 60 
Ich sprach oft mit Dr. Ambros bei meiner Anwesenheit in Ludwigshafen im Jahre 1941. Nach meiner Kenntnis war Dr. Ambros mit der Verantwortung fuer die gesamte Buna-Herstellung in I.G. Farben betraut. Er besuchte das Lager in Auschwitz waehrend meiner Zeit 2- oder 3 mal. Ich sah ihn verschiedene Male im Buna-Betrieb Auschwitz.

Ich nehme bestimmt an, dass Dr. Ambros sowohl wie alle anderen Besucher des Auschwitzer Lagers ueber die Vernichtung von Menschenleben in Birkenau Beschied wussten, da in der Stadt Auschwitz, den Bunawerken und der restlichen Umgebung des Auschwitzer Lagers von den Ausrottungen ganz allgemein gesprochen wurde. ${ }^{158}$

Thousands participated in the mass murders; many also believed in the Final Solution of the undesirables and Jewish Problem. Responsibility was only duty. Since German business leaders felt justified in fulfilling their duties professionally, correctly, and efficiently, and concrete rewards provided an index for their actions, they would not have betrayed their country until the outcome of the war threatened to shake up their economic interests. Except for the Weimar era, German economic development had been one in which the entrepreneurial classes had learned to rely on the established rulers to look after their politico-economic interests. But when political leadership faltered, I.G. Farben's leaders were prepared to protect their company and their individual profusion of power, whether it faltered during Weimar or in the Third Reich.

\section{IV.G. I.G. Farben: Preparing for Perpetuity}

Progress makes purses out of human $\operatorname{skin}^{159}$ (Karl Kraus)

158 Koehler, pp. 305-306

159 Karl Kraus, Half-Truths and One-and-a-Half Truths (Chicago, 1986), p. 122 
During the final phase of the war, the industrialists and the German people knew that the Reich was in trouble. "Die Arbeitszeit geht vielfach ueber das normale Mass hinaus und liegt im Durchschnitt bei ca. 56 bis 58 Stunden, einzelne Betriebe arbeiten bis zu 70 Stunden..." 160 Characteristic of this phase was a report made by the Regierungspraesident of lower Bavaria who noted on June 10, 1944 that,

In manchen Zweigen der Industrie ist die Arbeitslast fast unertraeglich geworden. In den Eisen- und Stahlwerken wurde die Arbeits zeit zum Teil auf zwoelf Stunden verlaengert. Dabei haben viele Arbeiter noch Anmarschwege von fuenf bis fuenfzehn Kilometer zur Arbeitsstelle zurueckzulegen und muessen meist noch eine kleine Landwirschaft betreuen. Es ist verstaendlich, dass eine solche Ueberbeanspruchung Missstimmung erregt...Die Dienstverpflichtung deutscher Arbeitskraefte kann vielfach nur noch mit polizeilichem $Z$ wang durchgefuerht werden... ${ }^{161}$

The longer the war continued, it became clearer that German defeat was not only a possibility, but inevitable. I.G. Farben's leaders perceived as early as 1942 that they would have to "...try to minimize the effects of Allied policy in the event of an increasingly likely Allied victory." 162 I.G. Farben's leaders began planning for its company's future, not so much with plans of a victorious Drang nach Osten, but upon the assumption of German defeat.

It is significant to note that the exhaustive use of slave labor after 1942 paralleled the sense of resignation among the company's elites. In order to avert the worst consequences of German defeat, I.G. Farben transferred patents and other company assets

160 Harald Focke and Uwe Reimer, Alltag unterm Hakenkreuz (Hamburg, 1981), p. 168

161 Ibid., p. 169

162 Stokes, Divide and Prosper, p. 31 
to Spain, Portugal, Switzerland, Sweden, and South America. Particularly during the closing months of the war, a

number of German tourists were seen...with Spanish bankers and with representatives of the enterprises controlled by I.G. Farbenindustrie with their branches in Portugal and South America. The purpose of their discussions was...(to) transfer the ownership of German assets to Spanish nationals in order to try to avoid confiscation by the Allies. ${ }^{163}$

I.G. Farben representatives made other moves to ensure the continuity of the corporation's enterprises in the event of an Allied victory.

Carl Krauch denied at Nuremberg that I.G. Farben named a leading technician Ulrich Haberland the director of the Bayer group of factories in 1943 in order to ensure continuity of the director's position in the company's management. Since Haberland was not appointed to the managing board, Farben's leaders surmised that the Allies might be less likely to remove him after the war if Germany goes down in defeat. "He could thus serve, possibly with others, as... a point of concentration for the reconstruction of the firm. Indeed, he was to become the leading figure of Bayer AG, which together with several other companies was formed from the broken-up I.G. Farben." 164 Haberland would be protected from punishment, and the Bayer leadership at Leverkusen would be spared.

In September, 1943, there was another major shift in Farben's leadership. Karl Winnacker was to be appointed divisional director of I.G. Farbenindustrie Hoechst at Uerdingen. According to Winnacker, between 1941 and 1943, Vorstand member Fritz ter Meer had met with him frequently but "never spoke a single word concerning my

163 Ibid., p. 32

164 Berghahn, p. 59 
(Winnacker's) personal future."165 Yet when Winnacker was appointed to his new position in 1943, "ter Meer regarded the matter as extremely urgent, and fully expected that I should start my new job in Uerdingen in a few days." 166 The plant at Uerdingen had been originally soid to I.G. Farben in 1926 by Fritz ter Meer's father, but the ter Meer family still represented local power in the area.

In any case, Professor Karl Winnacker, the Chairman of the board of management from 1952 to 1969 and later Chairman of the supervisory board of Farwerke Hoechst A.G. mused reflectively about his early career responsibilities at IG Farben:

I occupied a responsible position in the I.G. Farbenindustrie for a comparatively short period of time. I had started in the Hoechst works in 1933. During my twelve-year career I had been employed as a chemist in the dyestuffs laboratory, as a process engineer, as departmental manager of inorganic production, and as divisional director. That I never reached the last milestone, the technical direction of Hoechst and thus probable promotion to the board of management of the I.G., could be regarded only as a piece of luck in 1945. Had I got that far, then, like my colleagues and superiors, I would have had to face the Nuremberg tribunal. ${ }^{167}$

In view of the course that the war was taking, the forty-year-old Winnacker's appointment was intelligently planned by Farben's managing elites.

Farben's third major subsidiary, BASF in Ludwigshafen, was not as meticulous in preparing for post-war continuity. Professor Karl Wurster, a member of I.G.'s managing board, the NSDAP, and later defendant at Nuremberg, had been director of the Upper Rhine group (BASF) since the 1930s. After his acquittal at Nuremberg, he continued service for I.G. Farben as director of the Upper Rhine group at BASF. At the same time,

165 Winnacker, p. 104

166 Ibid., p. 99

167 Ibid., p. 17 
five of the eight members of BASF's managing board in the immediate post-war breakup period...were employees of the Upper Rhine Group during the war. These included Wurster and his deputy Bernhard Timm (later chairman of the managing board). At least twelve of the fifteen members of the managing board at Bayer in the early 1950s had been in the Lower Rhine Group of the I.G. and at least four of eight were members of the Hoechst managing board and were managers in the Maingau Group (Middle Group) ${ }^{168}$ during the Third Reich.

I.G. Farben had begun to restructure its interests and resources in anticipation of the Reich's defeat. On May 19, 1944, Carl Krauch, Heinrich Buetefisch, and E.R. Fischer, Chairman of the Board of I.G. Farben met with top military and government officials that included Keitel, Goering, and Hitler to discuss the vulnerability of chemical plants to Allied bombing. Particularly concerned after the recent bombing of the Leuna works, the elite representatives of I.G. Farben countered Hitler's "stereotyped interjections such as: "You'll manage it somehow,' or 'We've been through worse crises"169 with data supporting the precarious situation of their plants and the Reich. At the time, Hitler acknowledged their insights, "but a few months later, when the worst had already happened, he no longer wanted to acknowledge these insights."170 In any case, it was obvious to the Vorstand at I.G. Farben that the end of Hitler's Reich was near. Since I.G. Farben had played a central role in the rise and downfall of Hitler's regime, dissolution of the cartel would become a strong possibility with defeat of the Reich.

168 Stokes, Divide and Prosper, p. 183

169 Albert Speer, Inside the Third Reich, trans. from the German by Richard and Clara Winston (New York, 1970), p. 447

170 Ibid. 


\section{IV.H. The "De-Nazification" of I,G. Farben}

We are the trustees of the most infamous and fraudulent bankruptcy in history. ${ }^{171}$ (Theodor Heuss)

There is also an undercurrent of Anglo-American upper-class hostility to the trial of war criminals; once begun, it would be almost impossible to protect financial and business opposite numbers in the Axis counties from punishment. There is a subtle international solidarity here that is not the least of obstacles to just punishment of Axis murderers and the men who profited by Axis crimes. ${ }^{172}$ (I.F. Stone)

In his autobiography, Karl Winnaker, Farbwerke Hoechst chief executive officer wrote, "the collapse of the (National Socialist) state ...engendered an understandable breakdown of social order. Until then, the employees had been fairly disciplined....(but now) accepted moral values had lost their validity and sacred ideals and principles had been dishonored with the result that conventional concepts of property and ownership became blurred also." 173 In the same breath that he referred to the "lost" validity of moral values, sacred ideals and principles, Winnacker mentioned that many early Nazi party member "victims" "had recognized the true character of the regime,...far more clearly and far earlier than others who joined the party at a much later date."174

Winnacker was not a party member, yet he was appointed by Party member Farben executives to direct Hoechst from behind the scenes as early as 1943. As foreseen by Nazi Party member, Fritz ter Meer, Winnacker would be classified as 'not accountable' for crimes against humanity and would be allowed to continue directing Farben's interests in a leadership capacity, since he had not held a position in the Vorstand during the Hitler

\footnotetext{
171 Marsh, p. 27

172 Stone, p. 262

173 Winnacker, p. 114

174 Ibid., p. 115
} 
years. Following the war, some Farben elites were held accountable for their unconventional methods to gain economic stability and success for their cartel, particularly during the final years of the Third Reich.

De-Nazification measures were not evenly applied, were often ineffective, and were primarily a legal demonstration to show the world what the Germans had done. The Nuremberg Military Tribunal, which was the legal instrument the Allies used to denazify Germany, would only temporarily idealize a "just" world at peace. "[D]ie Nuernberger Kriegsverbrecherprozesse seien eine tragische Verhoehnung der amerikanischen Justiz." 175 The lost validity of moral values and validity of sacred ideals and principles which Winnacker discussed was not limited to only Germans. The allies that freed Europe of war in 1945 had become enemies by 1947-48, the period in which I.G. Farben's corporate elites would be called to trial for its participation in the Third Reich.

The I. G. Farben Case was one of twelve separate proceedings held before the U.S. Military Tribunals at Nuremberg in the U.S. Occupation Zone against citizens and officials of the German Third Reich. The authority for these proceedings of the International Military Tribunal stemmed originally from an Allied Declaration on German Atrocities released in Moscow on November 1, 1943. Top members of Farben industries were indicted by the tribunal for preparing and waging aggressive war, participating in a conspiracy to wage aggressive war, and other major counts which included crimes against humanity, plundering and deportation, enslavement and murder of large numbers of civilian populations, prisoners of war, and prisoners of occupied territories. The indicted elites included Carl Krauch, Hermann Schmitz, Baron Georg 
von Schnitzler, Fritz ter Meer, Heinrich Buetefisch, Heinrich Gattineau, and eighteen other top-level employees. (see Appendix)

Since 1940, the supervisory board of the firm (Aufsichtsrat) was chaired by Carl Krauch. Under Aufsichtsrat supervision, the Vorstand actually controlled the day-to-day business and operations of I.G. Farben. Since Hermann Schmitz had been Chairman of the Vorstand since 1935, he occupied a chief position among the I.G. Farben elites.

Schmitz, who was hand-picked in the 1930s by Carl Bosch to be his successor at I.G. Farben, "was in charge of its foreign empire and the principal architect of the company's vast overseas holdings." 176 He had originally attracted Bosch's attention as "a bright young man in the War Raw Materials Office who had helped him (Bosch) secure the approval of the German Government for the building of the Leuna high-pressure chemical plant in the spring of 1915."177 Bosch had also arranged for Schmitz to accompany him at Versailles representing the German Ministry of Economics, after which Schmitz joined BASF as its chief of finance and foreign operations. ${ }^{178}$

Besides his affiliation with I.G. Farben, Schmitz was also Director of the German Bank of International Settlements, Chairman of the board of directors of the American I.G. Chemical Corporation in New York and I.G. Chemie in Basel Switzerland. He had been well-connected to pre-Hitler Chancellor Bruening, who offered him a position in his cabinet, and U.S. President Herbert Hoover, with whom he visited at the White House. ${ }^{179}$

As a top-level Vorstand elite, Schmitz had access to inside government information and played a significant role in the expansionist policies of the Third Reich.

\footnotetext{
176 Borkin, p. 165

177 Ibid., p. 34

178 Ibid., loc. cit.

179 Ibid., p. 166
} 
At Nuremberg, it was admitted that Hermann Schmitz's office had contributed 100,000 Reichsmarks to the Sudeten German Relief fund in 1938. The money from the chief member of I.G. Farben's supervisory board was used to incite border riots eight days before the signing of the Munich Pact, which diplomatically endorsed a "return" of Boehmen und Maehren to Germany itself. After the Pact was signed, Schmitz wrote Hitler the following telegram: "Unter dem Eindruck der von Ihnen, mein Fuehrer, erreichten Heimkehr Sudetendeutschlands ins Reich stellt Ihnen die IG-Farbenindustrie Aktiengesellschaft zur Verwendung fuer das sudetendeutsche Gebiet einen Betrag von einer halben Millionen Reichsmark zur Verfuegung." 180

Schmitz was no doubt preparing to expand into the Sudetenland, even before Hitler had made the final political agreement with Chamberlain to invade the territory. I.G. Farben had counted on acquiring two plants owned by the largest chemical company in Czechoslovakia, Aussiger Verein. "Under the formula applied by Nuremberg laws, Aussiger could be classified as a Jewish company. Twenty-five percent of its directors were non-Aryan." 181 Within four years under Hermann Schmitz's leadership, I.G. Farben had acquired Skoda Werke Wetzler in Austria and Aussiger Verein in Czechoslovakia. Both acquisitions were hostile, since there was no possibility that these firms desired to merge with I.G. Farben. Poland and the small community of Auschwitz in Polish Silesia would be next on Farben's table.

Implementation of the Third Reich's racial policies by I.G. Farben reached its peak at Auschwitz. Having "assured themselves of the viability of the investment using traditional methods of business decision making, I. G. Farben's leaders decided in 1941 to

180 Janis Schmelzer, Massenmord: ueber die Blutschuld der I.G. Farben. Dokumentation zum Auschwitz-Prozess (Berlin, 1964), p. 97

181 Borkin, p. 97 
establish a plant - primarily for producing synthetic rubber, methanol, and oil - near what was to be a factory for murdering the victims of Nazi racial policies" 182 Scholars such as Stokes maintain that there is no evidence to support the hypothesis that abundance of slave labor in the area was a factor in the I.G. Farben decision to build a plant near Auschwitz. "Auschwitz's marshy and malarial ground offered an inauspicious setting for a concentration camp, let alone a factory." 183 Although it has been argued that the "regime's insistence on an eastern location... won Ambros over before the possibility of employing inmates emerged," 184 it is more likely that geography was a determining factor in locating the camp at Auschwitz because the "SS had plans to expand enormously a concentration camp nearby." 185 In any case, most scholars agree that "top officials of the chemical compound knew about the killing, and there is no evidence that they considered any course other than going along with the butchery." 186 The company's leaders constructed and operated the plant even when "the stench of the incinerators must have brought questions into the minds of visiting I.G. executives." 187 There is no doubt that the human mass sufferings at Auschwitz and other $K Z s$ contributed to the process of capital formation which steadily increased Germany's productive capacity throughout the war. Although it has been argued that I.G. Farben had originally planned to use primarily German workers at Auschwitz, "on April 7, 1941, Farben and the SS seemed on their way to an excellent working relationship. [Auschwitz Commandant] Hoess and his superiors had promised to furnish... basic materials to supply, train, guard, and help feed ...skilled

182 Stokes, Opting for Oil, p. 38

183 Konnilyn Feig, Hitler's Death Camps (New York, 1979), p.341

184 Hayes, p. 351

185 Borkin, p. 115

186 Ibid., p. 38

187 Stokes, Divide and Prosper, p. 28 
inmates,... all in return for Farben's paying the SS three to four marks for each worker's nine to eleven hour shift."188

It would be naive to believe that Farben elites did not plan to utilize resources available at the Auschwitz site at the foundation of the project, particularly since several Farben executives also held top positions in the NSDAP and its agencies. Most noteworthy were Chief of Sales and Vorstand member, Wilhelm Mann, and Chief of the Commercial Committee of the Vorstand, Georg von Schnitzler, both of whom were members of the SA. Heinrich Buetefisch, a lieutenant colonel in the SS was joined by Vorstand member Christian Schneider, also a member of the SS. These men and others on the I.G. Farben board were primarily actors, not reactors in the National Socialist state. Although historians disagree as to when the systematic killing of the Jews was set in motion, many agree that the operation began between the spring and summer of 1941 , approximately the same time that I.G. Farben executives were discovering their "excellent" working relationship with the SS.

Opportunism settled easily into the professional and corporate mind-set at I.G. Farben. Out of fear or national pride, many Germans could not abandon Verantwortlichkeit to their country during a time of war. At the same time, I.G. Farben reached its full strength in the Third Reich, but resolute financial ambition spawned complicity between corporate executives and the political structure. Business elites are traditionally initiators of national and international experience, and, not unlike politicians, formulate advantages in economic terms. Rather than taking an ideological or ultra-nationalist view of the world, business elites are generally more interested in how investments work for them. Unlike the military and the police who are generally held 


\section{Page 84}

accountable to legal standards, business leaders are in a class of their own. When there is wrong doing, the judgment is less severe for white collar crimes, regardless of the results of the crime.

Many believe that business transcends ideology, when in fact, business is an ideology. Business is a belief system which helps to structure how the world is understood and explained. These ideas or beliefs provide the basis for some kind of political action. The basis of a good business is the profitable business; therefore business leaders become molded by the economic ambitions they serve. Particularly under dictatorship, corporate leaders are forced to be pragmatic, which is nonetheless, their greatest attribute. The I.G. Farben elites had a significant understanding of the powers that molded the Third Reich.

\section{I. I.G. Farben: Post-War Metamorphosis}

Also kaemen die Zeiten der Unwissenheit, in denen man anstaunte, wieder. ${ }^{189}$ (Johann Gottfried Herder)

The unconditional surrender of German armed forces took place on May 7, 1945. This day of unconditional surrender known as Stunde Null or Zero-Hour was not the commencement of a new Germany, but, rather a cleavage in Germany's twentieth century. By July of the same year, four Allied powers, the United States, the Soviet Union, Great Britain and France, took up their final occupation zone positions, however, disagreement among them regarding the purpose of occupation ultimately determined the fate of the German lands as a whole. Within half a decade, two semi-autonomous

189 Johann Gottfried Herder, Von der Volksposeie der Voelker (Stuttgart, 1980), p. 73 
German lands would be proclaimed under the leadership of the United States and Soviet Union: Bundesrepublik Deutschland (BRD) and the Deutsche Demokratische Republik (GDR).

For most Germans in 1945, Stunde Null meant the end of the German Reich. Devastation of the German Reich led to a collapse of German social structure. As Voelker Berghahn puts it: "...all Germans seemed to be equals...No doubt despair and deprivation were widespread and millions thought there was no future. For others the end of the Nazi dictatorship raised great hopes and an optimistic belief in a new beginning." 190

Within three months after Germany's unconditional surrender, Britain, France, the United States, and the Soviet Union awarded themselves a zone of occupation. Under Allied leadership, an attempt was made to replace the institutions of the Third Reich with systems that would follow the lead of the two major political contenders for world power, the Soviet Union and the United States. The majority of the Germans survived the first miserable and hungry years of the occupation, but tens of thousands of captured German soldiers were executed or disappeared in post-war Soviet concentration camps. Although exact numbers are unavailable, between 1,500,000 and 3,000,000 Germans were sent eastward by the Russians to help construct destroyed areas, or in some cases, to serve time in prison for their participation in the war. Most did not return.

At the same time, it was not unusual for German soldiers to walk hundreds of miles westward in order to escape from their potential jailers, the Soviet authorities. Some of these Germans were also in danger of being indicted for war crimes in the informal setting of the countryside. There were other individuals and, indirectly,

190 Berghahn, p. 40 
corporations, who were indicted more formally, particularly at the military tribunals at Nuremberg. A consensus among the Allied governments did not officially exist to acknowledge the mass murders, atrocities, and war crimes against millions of civilians until "an agreement dated August 8, 1945, (was signed) among the United States, Great Britain, and the Soviet Union, it was decided to bring Nazi leaders to trial. The decision was subsequently endorsed by nineteen member states of the United Nations." 191

The Nuremberg trials were intended to demonstrate to the world what the Nazis had done, but many of the courts were more interested in overcoming the devastation and putting the country in order again, rather than administering timely judgments for crimes against humanity, particularly in the business community. While political-economic objectives were eventually implemented by communist state-controls in the Soviet zone, the western zones, like Hitler, did not replace capitalism, since they realized that capitalist business and manufacturing interests were essential to achieving their objective. It is debatable whether the western military occupational authorities in the Reich were being directed by industrial and financial interests which, even during the war, had interlocking transnational connections, or the threat of communism.

Unlike the period following World War I, when there was a sense among intellectuals that Germany had been victimized in the Treaty of Versailles by Allied greed, there was little pro-German sentiment, even among German writers and intellectuals immediately following World War II. Germans and non-German collaborators in over five hundred thousand cases were found guilty of various "crimes against humanity." Penalties for some "top Nazi war criminals" were reasonably harsh, but from the beginning of the process, United States military intelligence officials and

191 Louis L. Snyder, The War (New York, 1964), p. 624 
administrators "believed that a distinction should be made between scientists like (Wernher) von Braun, who had joined the Nazi Party and the SS for what Americans termed 'opportunistic' reasons, on the one hand, and the various German experts who had supported Nazism for ideological reasons or who had directly participated in atrocities."192

Besides important scientists like von Braun, other men who were "sensible," respected, and well-dressed were thought not to have committed serious crimes in the Third Reich. Collaboration with the Third Reich usually had a two-sided character. On one hand, for example, collaborators may have acted on behalf of National Socialist government racial policies, and still lay claim to having acted in opposition to Hitler's government at the end of the Third Reich. Such collaborators were also useful in undercover OSS operations.

...Deutsche gegen Deutsche ist kein Weg zum Frieden. ${ }^{193}$ (Die Zeit, May $6,1948)$

According to the Joint Report on the Results of the Anglo-Soviet-American Conference (the Potsdam Agreement) in August of 1945: "All members of the Nazi Party who had been more than nominal participants in its activities and all other persons hostile to allied purposes shall be removed from public and semi-public office, and from positions of responsibility in important private undertakings." 194 Learning the lessons

192 Christopher Simpson, Blowhack (Monroe, Maine, 1993), p.33

193 Fr, "Deutsche gegen Deutsche," Die Zeit, May 6, 1948, p. 1

194 Richard Sasuly, I.G. Farben (New York, 1947), p. 267 
from "failures" of the Weimar Republic, the Allies' first concerns of De-Nazification involved a determination to prevent a resurgence of all nationalist parties.

Not only the nationalists, but all aggressive political activity was suppressed by the Allied Military Governments (AMG); even anti-fascist groups which rose spontaneously in a number of cities to organize local services and eliminate Nazis were outlawed in the Western zones. By eliminating the old nationalist right and postwar radical left, it was believed by some visionaries that moderation and stability would lead Germany to an ultimately democratic society. Some scholars have also suggested that the AMGs' intolerance of such extremist groups forced Germany to miss its chance for a genuine democratic renewal while they fueled the coals of the Cold War.

During the Nuremberg Trials, German corporations were legally perceived as individuals. Firms, as well as certain individual elites, were also to be treated with special consideration. One of the most conspicuous was Daimler-Benz, the motor and engineering firm which was one of the major beneficiaries of Hitler's armaments buildup. Unlike the post-war metamorphosis of I.G. Farben, Daimler-Benz has remained unscathed by the Nuernberger Prozesse. It continues to manufacture a high-status product, while being one of the Bundesrepublik's most powerful conglomerates.

Daimler-Benz was a typical example of most German companies during the Third Reich, which tended to act as a solvent on moral and social traditions. Like most other important German firms; it made extensive use of forced labor between 1941 and 1945. "Twenty-four per cent of employees at twenty-two large German companies were foreign workers and prisoners by 1942."195 At its peak in 1944, more than 37,000 civilian

195 Bernard Bellon, Mercedes in Peace and War (New York, 1990), p. 241 
forced laborers, POWs, and concentration camp inmates were employed by the automobile and armaments corporation. This was more than half of their work force 196 Benz had also contributed much to industrial growth in Germany prior to World War I. As early as 1912, the Prussian War Ministry had begun to subsidize the production of large utility vehicles at a small Benz factory in the suburbs of Berlin. During the War, Daimler-Benz, a Wuerttemberg company with the vast majority of whom laborers were members of the Social Democratic Party, continued to serve the Imperial German Government. In 1918, the General Director Ernst Berge and a number of his associates faced charges of war profiteering, falsification of price documents, and treason. Nevertheless, Benz continued to be a "reputable" company, receiving an infusion of loans by the Deutsche Bank, even when profitability was tenuous.

Some of Benz's plants were doing well. Even though car prices were low, Mercedes had been selling large numbers of trucks to the Soviet Union. By the end of 1930 , the firm was also at work on the construction of two-test model tanks.

Nevertheless, layoffs and wage cuts in their Sindelfingen factory provoked the workers to organize mass meetings, and they attempted to assemble a strike committee. It is here that the National Socialists began to get a foothold in the factories. In 1931, about "onethird of the clerk representatives at Daimler-Benz were Nazis," 197 while the company, itself, was drastically curtailing its advertising in the SPD Vorwaerts and increasing it in the NSDAP Voelkischer Beobachter. ${ }^{198}$ During the World War II, the company received slaves from Sachsenhausen, ${ }^{199}$ was responsible for killing Jewish slaves in Poland, 200

196 Ibid., pp. 230-231 loc. cit.

197 Ibid., p. 217

198 Ibid., p. 219 loc. cit.

199 Ibid., p. 242 loc.cit.

200 Ibid., pp. 246-247 loc. cit. 


\section{Page 90}

and sent some of their profits to Switzerland. ${ }^{201}$ Today, the Mercedes insignia, a three pointed star framed by a circle, represents "having made it."

The star, which originally symbolized the omnipresence of the corporation in land, sea, and air transport, has played a prominent role in war and peace. During the Third Reich, the Daimler-Benz star became an all around arms conglomerate, building even torpedo heads and parts for Hitler's secret V-2 rockets. Even so, this prestigious corporation paid no compensation for its use of slave labor program until 1988 when "Daimler decided to give DM 20 million to the U.S. Jewish Claims Conference and other humanitarian organizations to ease consequences still ensuing from those times." ${ }^{202}$ As a corporation, Benz has flowed with the tide and fit well into each of the German governments of the last hundred years.

Gustav Krupp became too senile to be tried at Nuremberg, while the younger Krupp, Alfried, went on trial in one of the post-war tribunals. He was jailed on charges of plundering occupied territories and using slave labor from concentration camps. A member of the SS and the Nazi party, Alfred was convicted in 1948 and served three years of his twelve-year sentence. Two years after his release from prison, Alfried was allowed to return to his position as head of the Krupp firm with the stipulation that he would divest himself of his major interests. ${ }^{203}$ This condition was never enforced, and the Krupp Works once again became the biggest steel producer in Europe.

While the de-Nazification program in the East called for the shipment of capital goods to the USSR, the public roles of I.G. Farben executives were to be assessed at the

201 Ibid., p.239 loc. cit.

202 David Marsh, The New Germany (London, 1989), p. 19

203 Tribunal Judgment 7/31/48 Ntr 13231-13402, also see William Manchester, The Arms of Krupp (New York, 1970),p. 760 
trials in Nuremberg by other capitalist polities. Twenty-four executives would initially receive no more than eight years in prison for their part in the Third Reich, and the longest time served was less than a decade. "Im IG-Prozess wurden zehn Angeklagte freigesprochen, die uebrigen dreizehn ehemaligen Direktoren erhielten Gefaengnisstrafen von ein-und-halb bis zu acht Jahren."204

For most Germans, the sentences dished out were arbitrary decisions made by the victorious powers. Due to the increased tensions of the cold war, the Allies were more preoccupied with rehabilitation of the country and restoring its lost economic strength in the face of a new Communist adversary than with criminal proceedings. This tendency was strongly demonstrated by the number of pardons and reduced sentences granted to criminals who had been convicted during the first post-war years. The I.G. Farben trial, which ended in the summer of 1948, was on the cusp of this process.

The successful attempt of the Allied governments to maintain moderation and stability in post-war Germany gave (entrepreneurs) a new state in which they could believe. The only punitive action which the Allies took toward these German capitalists (besides in certain cases, war guilt), was "to take over his industrial secrets and knowhow, to fix a ceiling on certain types of production, and to break up the great concentrations in industry, especially in the Ruhr, in the belief that these great concentrations of power had worked for war and had enabled Hitler to wage it successfully."205

"After World War II, all of the I.G. Farben confiscated patents became the property of the American chemical concerns, which thus saved many years of costly

204 A.B., "Wochenuebersicht," Die Zeit, August 5,1948, p. 7

205 Lewis and Stewart, p. 178 


\section{Page 92}

research. Successors of I.G. Farben had to start again at scratch after the war and overtake all competitors, to be able to offer the world market new products to compete for a foothold." 206 The role of I.G. Farben may have been limited in bringing the National Socialists to power, but the firm had thoroughly supported the regime once it came into power.

Not only would I.G. Farben lose their patents, proponents of American policy immediately at the end of the war proposed a radical plan to deconcentrate the company. The Allied deconcentration program was not limited to I.G. Farben's holdings, but was to have been "carried out in three major sectors: breaking up of the large coal and steel combines of the Ruhr; the survivors of the Big Six commercial banks, and the giant I.G. Farben trust - the world's largest chemical firm. In order to discourage German industry from future world-conquest opportunities, deconcentration of I.G. Farben was to create smaller companies out of the subsidiaries of the giant chemical cartel. At the end of the World War II in 1945, "about sixty per cent of the production capacity of I.G. Farben was located in the Russian zone, twenty per cent in the French zone, eleven per cent in the British zone and nine per cent in the U.S. zone."207

However, as the Allies poured money into the defeated country, strong entrepreneurs were given a chance to realign themselves in a new world order. Though structural changes had to be implemented, German business would emerge as the real architect of the post-war Wirtschaftswunder, at least in the West. In no company is that more evident than in the dismantled I.G. Farben.. Although the I.G. Farben name has "vanished," a sprawling confederation of separate companies have metamorphosed from

206 TheNew York Times, July 26, 1952, p. 26. [an unsigned news story]

207 Hartrich, p. 88 
the larva of the German chemical giant. Today, the three major successor companies of I.G. Farben - Bayer-Leverkusen, Farbewerke Hoechst, and BASF of Ludwigshafen - are each bigger than that their parent I.G. Farben ever was." 208 While the surviving political and military elites were rushed off to the gallows or to prison to serve life sentences for their collaboration with the genocidal regime, the outcome of the denazifying of business enterprises was less clearly defined.

Indeed, attempts to dismantle I.G. Farben did not fully succeed until ten years after the war; by then, its offspring companies were beginning to participate fully in world trade. General Order Number 2, issued by the AMG authorities to liquidate $I$. $G$. Farbenindustrie $A G$, was to become effective on July 5, 1945.(see Appendix) In accordance with American Military Government, the Potsdam Agreement was signed, taking into account measures by which 'Nazism would be extirpated' 209 On September 19, 1945, writing in The Nation, journalist I.F. Stone observed:

Hardly a day passes without new evidence that...directives are being sabotaged by the military occupation authorities in the Reich. Big American industrial and financial interests interlock with those of Germany as of Japan. Their influence, plus brass-hat mulishness, is enough to nullify the most specific directives. For Germany, these are severe and thorough, but that has not kept them from being ignored. Even so conspicuous a malefactor as I.G. Farben is successfully evading the fate decreed for it. I have seen secret General Order No. 2 on I.G. Farben, issued last July 5 by Military Government authorities. It is very drastic, but it is not being obeyed. Instead of being liquidated in accordance with the order, I.G. is being rebuilt. I am reliably informed that the services of its old American subsidiary, General Aniline and Film, are being enlisted to provide technicians for the reconstruction of the parent German company. Only last Friday the United States reported from Frankfurt a press conference in which Colonel James Boyd, head of the United States

208 Hartrich, p. 87

209 see Sasuly, p. 266 
Forces Industry Branch, declared that I.G. Farben's war industries would be 'switched' to peace-time output rather than be destroyed....If I.G. can thus save itself, so can Mitsui. 210 (Mitsui did save itself!)

The Allied Military Government's written objectives regarding de-Nazification, as well as sections in the Potsdam Agreement, were obscured from the beginning. General antagonisms made it impossible for the four-power Allied Control Council to enact unanimous decisions regarding its prescribed reconstruction and de-Nazification. From the start it had been Washington's plan to rehabilitate survivors of the National Socialist state by eradicating "weapons of economic warfare... German cartels (which) were utilized by the Nazis as government instruments to achieve political ends." 211 Even among I.G. Farben executives who had begun to restructure management elites and protect corporate hierarchy for the sake of continuity, years before the war ended, there had been a sense that the cartel would be convicted of wrong doing during the war and broken up But after the AMG ordered its dissolution, I.G. Farben stock began to reappear on the stock market. It turned out that I.G. Farben would outlive its own burial. Investigations into I.G. Farben's operations determined that a "Colonel Edwin S. Pillsbury had been set up to take special care that I.G. Farben should not be rebuilt....except as may be specifically determined to be in accordance with the objectives of the United Nations."212 In line with the United Nation's "objectives," I.G. Farben had resumed production in plants throughout the U. S. Zone, under the direction of General Dwight Eisenhower.

210 Stone, p. 319

211 The New York Times, September 9, 1944, p. 10. [an unsigned news story]

212 Sasuly, p. 198 
During this early "de-nazification" period, the "Germans' requests for production authorizations were always approved, sometimes even boosted, "213 Democratization of the German economy was Washington's particular plan to coordinate post-war rehabilitation. Generally, the occupying powers in the West had "failed to deal with the roots of German militarism -- capitalism and large-scale land ownership," 214 while they, themselves began to align with their former enemy.

While for the next three years, the Soviet Union indiscriminately dismantled their production capacity of I.G. Farben and other industrial plants, the forty-three manufacturing plants belonging to I.G. Farben in the U.S. zone were positioned to be utilized for the successor companies of the chemical giant. The initial concern of the occupation authorities in the U.S. zone was to break up the large combine and deconcentrate control over production in a manner similar to U.S. anti-trusts laws. But as the cold war intensified, the deconcentration policy lost its initial appeal to the occupation forces.

ln order for western Europe to be strong, Germany had to be strong. As a result, the original deconcentration list for I.G. Farben

was revised to forty-two successor companies, then to twelve units, and finally to five - leaving virtually intact the physical establishments of Bayer-Leverkusen, Farbwerk Hoechst, and BASF at Ludwigshafen, plus two smaller firms, Chemische Werke Huels and Cassella Farbwerke Mainkur of Frankfurt. Farben stockholders received nine new shares in a successor firm for ten old shares. ${ }^{215}$

213 Ibid, p. 199

214 Dorpalen, p. 487

215 Ibid., p. 89 
It could be claimed that the Western Allies' policy of dismantlement aimed at I.G. Farben was eventually successful because the old chemical trust was broken up. Nevertheless, I.G. Farben's 'dismantled pieces re-emerged in a form not very different from the old cartel, and with many of the same people directing it.(see appendix) In 1951, Konrad Adenauer's Christian Democratic government reestablished West Germany's standing in the world by offering financial payments to individuals and families of Jews and other groups who had been persecuted and killed by Hitler's regime. Six years after the Adenauer government decided to pay this restitution, the receivers of the twelve component parts of I.G. Farben "paid DM 30 million to the United States Conference on Jewish Material Claims against Germany in compensation for the company's treatment of Auschwitz prisoners."216 In order for the restitution to be not interpreted as an admission of guilt, I.G. Farben's "gesture" was made on a purely "voluntary" note. I. G. Farben paid no compensation for non-Jewish laborers.

Superficially, the I.G. Farben cartel has vanished, but it has been replaced by oligopolies of the same lineage. "Each now is far larger than I.G. Farben at its zenith. BASF, Hoechst, and Bayer are multinational giants with total turnover in 1989 of DM133 billion. In the U.S. alone, the three companies now have a combined turnover of $\$ 17$ billion and employ 70,000 people." 217 Of the ten German stocks listed in the financial section of The New York Times, the values of the "Big Three" appear daily. The chemical giant of the Hitler Era has become a "bull" of the German Wirtschaftswunder.

216 Marsh, The New Germany, p. 17

217 Ibid., p. 15 


\section{SUMMARY}

The main points of this thesis are as follows:

- There has not been adequate attention to, nor study of the history of business elites, particularly in western industrial nations. This may be due to the immersion of scholars in a society which embraces the business ethos, and perhaps also to potential opportunities for corporate sponsorship. The pervasive disinterest in the analysis of business history and the tendency of businesses to maintain secrecy make it difficult for scholars seeking primary historical data in this area, and to document the mechanisms by which business elites exert their power.

- Business elites universally - and often aggressively - maintain their grip on the means of production, property and social privileges at the expense of the masses. The state and its military apparatus are used by elites as an instrument to build and hoard capital, and to compete effectively on a global scale; thus elites promote political systems which best serve their interests, and avoid implementing non-beneficial policies.

- The German industrial sector of World War II was rapidly developed during successive wartime economies beginning in the 1870 's; this fact contributed to its military-oriented production, an intense nationalistic competitiveness, and the progressive organization of competing companies into cartels, such as I.G. Farben. Their integration, intensified by Gleichschaltung, facilitated the mobilization of the 


\section{Page 98}

Nazi war machine, and intensified the drive towards territorial expansion in the interest of accumulating capital for the German state.

- German business elites initially aligned with the NSDAP to avert a winning political coalition dominated by the Communist Party, and to continue the Weimar policy of keeping oil import duties high. Indeed, they planned for their own continuity after the inevitable post-war demise of National Socialism. However, the commitment of big business elites to the Third Reich was eventually achieved through accelerating their state-sponsored subsidies, combined with other incentives such as control of labor organizations, acquisition of dispossessed property, and in the end, use of a free, portable and disposable work force.

- With its monopoly over the manufacture of products critical to the war effort, and its global business interests, I.G. Farben became one of the most powerful companies in the world during World War II., and an integral part of the Third Reich power structure. The Reich's policy of reducing dependence on foreign raw materials and detaching the country from unfavorable foreign exchange made it further dependent on I.G. Farben for the development of synthetic goods, diverting to the company enormous research subsidies and further fueling the growth of company profits. The company reciprocated with generous contributions to the NSDAP.

- Despite the initial plea of I.G. Farben executive Bosch to the Third Reich on behalf of Jewish associates and scientists, the company quickly moved to profit from the purging of Jewish executives and the acquisition of liquidated Jewish assets. Company directors not only became Party members, but intimates in the Nazi inner 
circle and SS members. As the war progressed on two fronts, I.G. Farben aggressively pursued the exploitation of slave labor, investing heavily in the building of Auschwitz, and in doing so, condemned to death millions of civilians in labor camps and concentration camps.

- During the post-war occupation of Germany, the Allied powers were soon preoccupied with Western European stability as a bulwark against Soviet communism; this, in part, contributed to the relatively light sentences handed to I.G. Farben and other German business executives, who in many cases were reinstated in their former positions. While Farben company patents were confiscated by the Allies, particularly the U.S., and the cartel deconcentrated, the three successor companies are now each bigger than their parent company ever was, with combined assets of seventeen billion dollars.

\section{CONCLUSION}

Germany always had two bosses: one the General Staff, and the other the Rhine industrialists. We still have the latter only a little chastened. Let us not take on the other for a while. ${ }^{218}$ (John McCloy to Henry Stimson June 28, 1950)

If industry can cooperate across the frontiers, then governments will follow. ${ }^{219}$ (Professor Hanson - Farbenfabrik Bayer)

218 Kai Bird, The Chairman (New York, 1992), p. 332

219 Anthony Sampson, Anatomy of Europe (New York, 1968), p. 101 
When I first began researching I.G. Farben's involvement with the Third Reich, I had little idea of the volume of material in this area. At the same time, it is only now in the last decade of the twentieth century that serious public discussion of the role of corporations in the Third Reich has emerged after forty years of meager academic interest in this topic. With few exceptions, notably the popular best-seller, William Manchester's The Arms of Krupp, scholarly research into the role of business in the Third Reich has been sparse or extremely politicized from the 1950s through the 1980s.

As is often the case, a history may not be dispassionately written until all participants are dead. When Fritz Fischer's controversial views in the 1960s regarding primacy of German guilt in causing the First World War were put forth, many scholars were initially outraged. Similarly, we have also arrived at the "magic" threshold at which events during the Third Reich may be subject to more critical examination.

During the Cold War period, NATO and the West did not want to offend its wealthiest European ally. Less than a half century later, most individuals, governments, and corporate representatives could claim that atrocities that engulfed Europe during World War II took place, according to the then popular saying, ohne mich.

Fifty years after the end of World War II, politicians and journalists have renewed interest in the business dealings of the Third Reich. Front page stories by journalists such as Alan Cowell of The New York Times have given impetus to the following stories: "Volkswagen's Past: Dark Side Revisited"(11/7/96), "Swiss Acknowledge Profiting from Nazi Gold"(12/14/96), and "Three Nations Agree on Freezing Gold Looted By Nazis"(2/4/97) In view of intensive efforts to study Hitler and uncover the Nazi past, it is not remarkable that these stories have been gaining considerable attention at a time when most participants have passed away from their professional positions and from life. Although firms like Daimler-Benz, Siemens and the components of I.G. Farben, which 
initiated complicity with Hitler's policies over fifty years ago still exist, contemporary concern about the "good names" of German companies may not be as vital to their success as it was a half century ago. "...und damit wird ein Punkt beruehrt, der vom deutschen Geschichtspunkt der wesentliche in diesem Prozess ist. Es geht hier nicht um einzelne Industrielle und Kaufleute, sondern um die Sauberkeit eines in der ganzen Welt beruehmten deutschen Firmenamens!"220

Ihr Appetit ist bodenlos

Sie fressen Gott und die Welt

Sie saeen nicht. Sie ernten bloss

Sie schwaengern ihr eignes Geld ${ }^{221}$ (Erich Kaestner)

It was the Nationalsozialistische Deutsche Arbeiterpartei (NSDAP) that initiated the Holocaust, not the industrial or financial elite, nor the German medical community, nor the German military. But the party enlisted a wide range of collaborators, including doctors, teachers, professors, and the military, among others. Josef Mengele, who has been called "the angel of extermination," 222 disappeared from a British internment hospital after the war, but there is little doubt that if he would have been caught, he would have faced the same fate as Adolf Eichmann. There seemed to be no problem for the world to hate a Dr. Mengele, the chief doctor at Auschwitz, as a single medical doctor can be replaced, and an individual who can be identified with a face and a name presents a visible target. However, the Third Reich's less visible Plenipotentiary for Labor Allocation was also held accountable for his deeds. The unknown Fritz Sauckel, the former Thuringian Gauleiter (District Leader) and later member of the Reichstag,

220 HGST, "Ein Konzern steht vor Gericht," Die Zeit, February 12, 1948, p. 8

221 Erich Kaestner, Laerm im Spiegel (Munich, 1988), p. 70

222 Snyder, Encyclopedia of the Third Reich, p. 227 
sent more than five million foreign slaves into the service of the Nazi war machine. He would receive the death sentence at Nuremberg; even though he could not accept the fact that he was to die merely for carrying out the orders of his superiors. ${ }^{223}$ Defendants like Generals Jodl and Keitel were "following orders", but again, government officials and generals are easily replaced. Who apparently could not be so easily replaced are geniusscientists and like Freiherr Wernher von Braun, businessmen like Gustav Krupp von Bohlen und Halbach and his son Alfred, or companies like I. G. Farben. Von Braun, a rocket researcher for Hitler's Reich, came to the United States in 1945. He eventually played an important role in all phases of the American moon flight program, and was a personal friend of President John F. Kennedy.

In the "best of all possible worlds", property provides individuals with a source of protection; those who possess and enjoy their own property are more likely to respect the property of others. But property, like all possessions, reflects the personality of its owner, particularly in the top echelons which are most fearful of stagnating resources. In capitalist systems, it is considered almost unethical to stop "struggling" toward all features of upward economic mobility, not least continuously expanding capital; this $k a m p f$ was also at the core of Hitler's ideological and socio-economic programs. For the corporate elite in the Third Reich, the regime served as an instrument to achieve everincreasing growth of institutional and personal resources through war profiteering and exploitation of free and disposable labor.

Major corporations are, often falsely, too closely identified with a specific state, particularly in our era of multi-national corporations which concern themselves with the welfare of the corporation above any allegiance to the state. To a decreasing extent,

223 Ibid., p. 306 loc. cit. 
Volkswagen is a "German" corporation, particularly as the supply and organization of material and labor are decentralized world-wide. Although this tendency towards globalism on the part of big business was evident in Germany of the late 1920s, its corporations were more decisively nationalistic in the 1930s and 1940s. After the Great Depression, which some blamed on the failure of the U.S. capitalist model, the National Socialists devised a plan by which "a German bloc...was to be expanded towards the East and the West by force of arms and then to be permanently secured by military means. This power bloc was to be taken out of the international system of multilateral political cooperation and peace preservation." 224

Among the privately owned German companies, I.G. Farben was the largest employer of concentration camp prisoners. As early as 1942,

Farben's total number of workers reached 200,000, of which approximately fifty per cent were slave labor. Poison gasses and various deadly pharmaceuticals manufactured by Farben and supplied by Farben to the officials of the SS were used in experimentation upon and the extermination of enslaved persons in concentration camps throughout Europe. $^{225}$

In the context of author David Schoenbaum's assertion that in the Third Reich "there were no... reliable indications of what was up and what was down," 226 there were, nevertheless, "opportunities available during this period which strengthened... concentration of monopoly power by such large firms as I.G. Farben."227 Executives at I.G. Farben may have become "prisoners of the process they prized most: competition,"

224 Berghahn, p. 27

225 The New York Times, May 4, 1947, p. 54. [an unsigned news story]

226 Schoenbaum, p. 281

227 Williamson, p. 32 
${ }^{228}$ but their professional 'competition' was an impetus to a system that encouraged the powerful to systematically destroy the powerless. Whether politicians induced or coerced this institutional behavior, the partnership between I.G. Farben and NSDAP executives "reminds us that, when political changes condition profit making in ways that tend to have immoral results, a capitalist system will prove strikingly malleable."229

One of the great ironies of this period is that while nationalist and militarist elites were not allowed to participate in the building of the post war order, industrialists and business executives were granted legitimate leadership roles in the new state. Executives in major cartels like I.G. Farben and Krupp, as well as less-significant elites, dominated policy-making during the early Wirtschaftswunderjahren in the Bundesrepublik.(see appendix) These "miracle" conditions were designed to subsidize economic order in a nation in danger of gravitating toward the Soviet Union.

The increasing number of academicians with Leftist views like Tim Mason, have acknowledged that it is "impossible to speak about fascism without speaking of capitalism [and]that genocide was at least as basic to Nazi purposes as class war." 230 The pact between members of Hitler's racist ideology and the industrial elites' program of substantially increasing profits and reducing the minimum price of labor came together at Auschwitz and other KZs. Representatives of I.G. Farben and other cartels "acted as efficiently within the Nazi bureaucracy as they had in their own organization."231 With iced hands, they plucked out surplus labor from Jews, Poles, and other "throw-away machines," in order to expand industry and to maintain an upward curve of their

228 Hayes, p. 380

229 Ibid., p. 381

230 Schoenbaum on Mason H-Netbook review, p. 5

231 Snyder, Encyclopedia of the Third Reich p. 178 
industrial profits. Many of these same individuals presided over the same companies after World War II. Believing that they lacked an alternative means of controlling postwar destabilization and revolutionary influences, the occupation governments lost interest in prosecuting elites.

"To an increasing degree, capitalist economies are directed by the entirely invisible hands of the monopolists, multinational giants and domestic oligopolists"232 Americans have generally mistrusted nationalists, militarists, big labor and big business, but Americans making important decisions in Germany after the war appeared to have been either closely associated with the latter or persuaded to put aside their misgivings about the same. Up front were names like McCloy, Forrestal, Averell Harriman, Philip Reed (head of General Electric), Allan Dulles and Ambassador to Germany, Robert Murphy. Upon ordering the release of an associate of Carl Krauch who had been interned for crimes against humanity, Ambassador Murphy made the following statement: "It is not in conformity with American standards to cut away the basis of private property." 233

Capable industrialists were needed to advance wiederaufbau, the war against communism in Germany, and in the end, it was commonplace that German business elites were not doomed to perish in the manner of their political leaders, their party, their National Socialist government, or even their country. On the shoulders of temporal political power, German elites transferred funds through their multinational and third country affiliations.

Although usually translated as accountability, the German meaning of

232 Robert Lekachman, Capitalism (New York, 1981), p. 170

233 Charles Higham, Trading With the Enemy (New York, 1983), p. 214 
Verantwortlichkeit is considerably stronger than its English counterpart. By definition, an accusation for which to be verantwortlich, denotes a degree of guilt. It implies that retribution must be made for any accused wrongdoing. Retribution was enforced in top level political, military, and even medical sectors of the Third Reich, but it has been argued that business leaders were "let off" with a slap on the hand. It became increasingly in the vital interest of western democracies to reconstruct post-war Germany into a viable capitalist buffer against the communist areas to the east. In turn, many of the large companies which prospered in the war economy of the Third Reich quickly reestablished their position in the western Bundesrepublik Deutschland. The enthusiastic commitment of German business elites to profit-making was considered vital in the war against communism and to rebuild the shattered western half of Germany. Once again, politics played handmaiden to profit.

Switzerland, neutral during the war, also has been accused of acting as Adolf Hitler's banker and laundering billions of dollars in gold looted from Jews and the central banks of occupied countries."234 Switzerland bought German gold, and according to the 1943 World Almanac, Adolf Hitler's annual income was reported at $\$ 12,000,000$ a year. ${ }^{235}$ More than just Jewish "gold" was sent to Switzerland and elsewhere. Since many business elites, had shuffled their priorities to fit into Germany's inevitable defeat midway through the war, financial safehavens were not overlooked. No executive from I.G. Farben was determined to follow their chancellor in death.

234 Alan Cowell, "Swiss Will Share Control of Holocaust Fund With Jews", The Oregonian, February 27, 1997, p. A5

235 June Foley, Mark Hoffman, and Thomas McGuire, editors, The World Almanac Commmemorative Edition (New York, 1992), p. 554 
Even during times of such upheaval, these individuals and corporations eventually resumed their traditional roles with what appears to be detached justification. Shortly after his early release from prison, industrialist Krupp, who had been convicted for crimes against humanity and plunder, was approached by a reporter and to whom he had described the above as "lesser crimes". Krupp "shrugged his shoulders and declined: Wir muessen noch einmal den ganzen verhandlungsbericht durchkauen. Ersparen Sie mir das, bitte." 236 He went on to defend his role in the Third Reich by explaining that "what a plant makes depends, after all, not only on the decisions of its owner, but also on official policies. "Mein Leben ist immer vom Lauf der Geschichte, nicht von mir selbst bestimmt worden."237 There is a sense of his self-proclaimed mystical mission of leadership in these words.

While a less centralized post-World War II Federal German state reflected a break with the Nazi past, the partition of German lands divided the industry of the German west from its prewar domestic market in the east. Skilled East German refugees and undervaluation of the German mark kept wages down. Long time members of the NSDAP and even the SS filled positions of honor and influence enthusiastically in the Bundesrepublik. Nevertheless, by 1949 in the eastern zone, "the task of Vergangenheitsbewaeltigung -- overcoming the past-- had already been completed, according to article 6, paragraph 1 of the East German constitution, which declares: The German Democratic Republic has...rooted out and destroyed German militarism and Nazism." 238

236 Manchester, The Arms of Krupp, p. 773

237 Ibid., p. 774

238 Peter Schneider, The German Comedy trans. from the German by Philip Boehm and Leigh Hafrey (New York, 1991), p. 155 
German corporate elites did not fare well in the Soviet Zone after the war, since a great many East Germans were dedicated toward building a socialist state. In the chemical industry, "the division of Germany into four zones caused production gaps and raw materials bottlenecks...Plants in central Germany and Upper Silesia were lost, and thus the integrated economy of the industry was largely ruined."239 Drueben was generally not conducive to the remnants of I.G. Farben's corporate leadership as it was in the West.

Tens of thousands left the GDR, but few, if any, business elites willingly stayed. For forty years, the GDR maintained a break with the German past and a "false tradition of a clear conscience... (until)...Hans Modrow's transitional government wrote to the World Jèwish Congress acknowledging 'the responsibility of the entire German nation' for crimes against the Jews." 240 Between 1989 and 1991, almost overnight, Herr Durchschnitt-ost had lost their country and their identity, but gained a new past to replace the old in order to participate pragmatically in a unified German state. Perhaps Herr Modrow believed that if the citizens of the GDR took responsibility for the Nazi past, it would be less detrimental for their professional and political reputations than their more recent dedication to a communist Stasi state.

Taken as a whole, motives which determined the actions of men who headed major German corporations such as I.G. Farben have received more attention behind the former "iron curtain" than in the West. It can be argued that effective businesspeople

239 Wilhelm Gratkopp, Heinrich Spieker, Dorothea Kempff, editors, Germany 19451954 (Schaan, Liechtenstein, No Date), p. 188

240 Schneider, p. 157 
have always made every effort to learn how customers prefer to deal and to "collaborate with the government to the best of its ability"241

As the Bundesrepublik was so easily swayed after the war from Nazism to democracy, fifty years later the authoritarian GDR followed suit. In 1990, "East German Finance Minister Theo Waigel called unification a 'zero hour'...(but)... some people realized they would never work again." ${ }^{242}$ Unlike the original Stunde Null, after which millions of Nazi party members remained in conspicuous positions of power, members of the SED were expelled "from university facilities, government offices and other public positions." 243 after zero hour number two.

West German firms expanded into the east, and the SED, VEB, and the FDGB became history. Again, there were trials. Once more, German politicians, the military, and, the police, served as proxies for business elites. Leading West German financiers, industrialists, and Junkers have privatized industry and replaced former land owners in the former GDR lands. The authorities which had the means of production in the best of the eastern economies were required to accept western capital investment according to Treuhand's terms. Unlike Daimler-Benz, Volkswagen, Siemens, and the Farben Group which have flourished since the war, most East German firms, including the nation's airline, Interflug, have gone under. The communist elite, the nomenklatura, has "disappeared", but many of these former top officials have made new connections with western entrepreneurs. It is still too early to compare the dynamics of "decommunization" and the de-Nazification in the late 1940s.

241 Dorpalen, p. 400

242 Marc Fisher, After the Wall (New York, Simon and Schuster), p. 187

243 Ibid., p. 188 
Fifty years after the end of World War II, Bayer, Hoechst, BASF and their subsidiaries continue to wield the inherited resources of I.G. Farben. Unlike the era of its death camps and forced labor, today, the former Farben Group members are run just as ethically as any business in a country with solid democratic institutions. Chancellor Helmut Kohl, former BASF employee and prior Hitler Youth member, has presided over Germany's liberal democracy for fifteen years. He speaks repeatedly about his "blessing of a late birth. My generation was too young to become involved in guilt." 244

Dr. Kohl, who was interested in political leadership "als Siebzehnjaehriger 1947 Mitgruender der Jungen Union"245 has incessantly articulated his generation's revolt against the generation of National Socialist "elders." His biographer Oskar Fehrenbach recounted the young man's Bildung:

For ten years Kohl worked for the trade association of the chemical industry, carrying out his political engagement in his free time. These were the years when Germany was still governed by the 'grandfathers,' who had gained their political experience during the Weimar Republic and had then opposed National Socialism. Kohl represented, as almost no one else did, the postwar generation,... which felt called upon to succeed the pre-war old guard. The generation in between was virtually absent from political life. ${ }^{246}$

It is unclear whether journalist Fehrenbach, who was born in 1923 and eventually became editor in chief of the Stuttgarter Zeitung, participated in the Third Reich but a generation of Kohl's NSDAP 'elders' did preside over west German politics. Bundespraesident Heinrich Luebke, Bundeskanzler Kurt Georg Kiesinger, and CSU

244 Hans Klein, editor, The German Chancellors (Chicago, 1996), p. 329

245 Wolf-Ruediger Baumann and Gustav Fochler-Hauke, Biographien zur Zeitgeschichte 1945-1983 (Frankfurt am Main, 1986), p. 282

246 Klein, p. 330 
leader Franz Josef Strauss bridged the Weimar generation with Kohl's united Germany. As a private contractor, Luebke built concentration camps at for the SS at Peenemuende and elsewhere, Kiesinger was a member "von 1940 bis 1945 der Rundfunkpolitischen Abteilung des Auswaertigen Amts als Referatsleiter Allgemeine Propaganda, Verbindung zum Reichspropagandaministerium,..." 247 and in 1943, Strauss "stand bedingungsloser Nationalsozialist zu sein nun an erster Stelle."248 Even former SPD Chancellor Helmut Schmidt had been a member of the Hitler Youth from 1933-1936.

Today, a united Germany continues to flourish as a highly cultural nation with a model education system. It also presides as the most important economic power in Europe. But unlike 1933, the world is not holding its breath to see what Germany can do with its institutions. History has taught us that the pendulum not only sways easily from democracy to a system like Nazism, but also back to liberal democracy if certain economic conditions prevail. Even in Eastern Europe, we have witnessed a relatively swift non-violent transition. There are always politicians and military leaders who avail themselves of the opportunity to take credit for these perceived breaks in historical continuity, but how often do they supplant the wealthowners in power?

My research has led me to speculate that business elites continuously adapt themselves to diverse state regimes, and are thus able to withstand even violent political transitions as long as the source of their essential materials and their markets are not disrupted. However, their participation in political life appears intended only to manipulate the instruments of state to maximize their profits.

247 Brent Engelmann, Schwarz Buch (Goettingen, 1986), p. 60

248 Ibid., p. 73 
To the extent that the leveraging of industrial and financial resources is essential for the survival of political regimes, big business is likely to continue to be the invisible architect of State policy. With their ownership of the large-scale resources needed to extract and process raw materials; their monopolization of technical expertise; their stewardship of key educational and social organizations; their skill in creating dependence on consumer products; and their personal insulation from the legal consequences of corporate wrongdoing, one might argue that the continuing dominance of elites in capitalist societies is assured.

Durch diese Handlungsweise uebernahm die IG eine grosse Verantwortung und stellte eine wesentliche und auf chemischen Gebiet entscheidende Hilfe fuer Hitlers Aussenpolitik, die zum Krieg und zu Deutschlands Ruin fuehrte. So muss ich den Schluss ziehen, dass die IG weithin fuer Hitlers Politik verantwortlich ist ${ }^{249}$ (Georg von Schnitzler I.G. Farben Vorstand )

\section{BIBLIOGRAPHY}

AB. "Wochenuebersicht". Die Zeit, August 5, 1948, p. 7

Appleby, Joyce, editor. Knowledge and Postmodernism in Historical Perspective. London: Routledge, 1996.

Arato, Andrew and Gebhardt, Eike, editors. The Essential Frankfurt School Reader. New York: Continuum, 1993.

Arendt, Hannah. Eichmann in Jersulem. New York: Penguin Books, 1992.

Avineri, Shlomo. Moses Hess. New York: New York University Press, 1985.

Axios, Costa. "Final Solution: The Schachtian Economy in the Third Reich." The

Campaigner, VIII (March, 1975), 15-41

Baumann, Wolf-Ruediger, and Fochler-Hauke, Gustav. Biographien zur Zeit-Geschichte 19+5-1983. Frankfurt am Main: Fischer Taschenbuch Verlag, 1983.

249 Nationalrat der Nationalen Front des Demokratischen Deutschland, NG, I.G. Farben Prozess, Dok. NI 5196, Braunbuch, (Berlin, 1968), p. 19 
Becker, Reinhard P., editor. German Humanism and Reformation. New York: Continuum, 1982.

Behrend, Hans. The Real Rulers of Germany. Ttranslated from the German by Charles Ashleigh. London: Lawrence and Wishart Ltd., 1939.

Bellon, Bernard. Mercedes in Peace and War. New York: Columbia University Press, 1990.

Berghahn, Volker R., The Americanisation of West German Industry. London:

Cambridge University Press, 1986.

Bird, Kai. The Chairman. New York: Simon and Schuster, 1992.

Bottomore, Tom., editor. A Dictionary of Marxist Thought. Cambridge, MA: Harvard University Press, 1983.

Borkin, Joseph. The Crime and Punishment of I.G. Farben. New York: Free Press, 1978 Brecht, Bertolt. Geschichten vom Herrn Keuner. Frankfurt am Main: Suhrkamp Verlag, 1980.

Bulabkins, Nicholas. Economic Aspects of Industrial Disarmament. New Brunswick, New Jersey: Rutgers University Press, 1964.

Burns, Emile., editor. A Handbook of Marxism. London: Martin Lawrence, Ltd., 1935.

Cantril, Hadley, editor. Public Opinion 1935-1946. Princeton, New Jersey: Princeton University Press, 1951.

Clapham, J.H., Economic Development of France and Germany. Cambridge: University Press, 1963.

Cowell, Alan. "Swiss Acknowledge Profiting From Nazi Gold." The New York Times, December 14, 1996, p. 4

Cowell, Alan. "Swiss Will Share Control of Holocaust Fund with Jews." The Oregonian, February, 27, 1997, p. A5

Cowell, Alan. "Three Nations Agree on Freezing Gold Looted By Nazis." The New York Times, February 4, 1997, p. 3

Cowell, Alan. "Volkswagen's Past: Dark Side Revisited." The New York Times,

November 7, 1996, p. 5

Craig, Gordon A., The Germans. New York: New American Library, 1982.

Chandler, Alfred D., Scale and Scope. Cambridge, Massachusetts: Harvard University Press, 1990.

Chesanow, Neil. The World-Class Executive. New York: Rawson Associates, 1985.

Conant, James. Germany and Freedom. Cambridge, Massachusetts: Harvard University Press, 1958.

Dahrendorf, Ralf. Society and Democracy in Germany. New York: W. W. Norton and Company, 1979.

Dorpalen, Andreas. German History in Marxist Perspective. Detroit, Michigan: Wayne State University Press, 1988

DuBois, Josiah E., The Devil's Chemists. Boston: Beacon Press, 1952.

DuBois, Josiah E., Generals in Grey Suits. Boston: Beacon Press, 1953. 
Eatwell, John. Milgate. editor. Problems of the Planned Economy. New York: W.W. Norton and Company, 1990.

Engelmann, Bernt. Schwarz Buch. Goettingen: Steidl Verlag, 1986.

Fisher, Marc. After the Wall. New York: Simon and Schuster, 1995.

Flechtner, H.J.F., Carl Duisberg. Duesseldorf: Econ Verlag GMBH, 1981.

Focke, Harald. and Reimer, Uwe. Alltag der Entrechteten. Hamburg: Rowohit, 1980.

Focke, Harald. and Reimer, Uwe. Alltag unterm Hakenkreuz. Hamburg: Rowohlt, 1981.

Foley, June and Hoffmann, Mark, and McGuire, Thomas, editors. The World Almanac

Commemorative Edition. New York: Pharos Books, 1992.

Fr. "Deutsche Gegen Deutsche." Die Zeit, May 6, 1948, p. 1

Franko, Lawrence G., The European Multinationals. Stamford, Connecticut: Greylock Publishers, 1976.

Friedrich, Werner. An Outline History of German Literature. New York: Barnes and Noble, 1966.

Gallagher, Richard F., Nuremberg: The Third Reich on Trial. New York: Avon 1961. Glouchevitch, Peter. Juggernaut. New York: Simon and Schuster, 1992.

Grosser, Alfred. Germany in Our Time. Translated by Paul Stephenson. New York: Praeger Publishers, 1970.

Grotkopp, Wilhelm, Spieker, Heinrich, Kempff, Dorothea, editors. Germany 1945-1954. Schaan, Liechtenstein: Boas International Publishing Company, No Date Grundberger, Richard. A Social History of the Third Reich. London: Penguin, 1991. Hardach, Karl. The Political Economy of Germany in the Twentieth Century. Berkely, California: University of California Press, 1976.

Hart, Jeffrey A., Rival Capitalists. Ithica, New York: Cornell University Press, 1992. Hartrich, Edwin. The Fourth and Richest Reich. New York: MacMillan Publishing Company., Inc., 1980.

Hayes, Peter. Industry and Ideology. Cambridge: Cambridge University Press, 1993.

Heine, Heinrich. Lyrische Gedichte und Balladen. Pittsburgh, Pennsylvania: University of Pittsburgh Press, 1987.

Heller, Robert. and Willatt, Norris. The European Revenge. New York: Charles Schreiber and Sons, 1975.

Herder, Johann Gottfried. Von der Urposeie der Voelker. Stuttgart: Philipp Reclam Jun., 1980.

Hermand, Jost, editor. Von deutscher Republik. Frankfurt am Main: Edition Suhrkamp, 1975.

Heywood, Andrew. Political Ideologies. London: Macmillan, 1992.

Hexter, J.H. "The Historian and His Day," from Reappraisals in History Evanston, Illinois: Northwestern University Press, 1962.

HGST. "Ein Konzern steht vor Gericht." Die Zeit, February 12, 1948, p. 8

Hilberg, Raul. Perpetrators, Victims, Bystanders. New York: Harper Perennial, 1992.

Higham, Charles. Trading With the Enemy. New York: Barnes and Noble, 1983. 
Hitler, Adolf. Mein Kampf. Translated and annotated by James Murphy. Los Angeles: Angriff Press, 1981.

Hobsbawn, Eric. The Age of Empire. New York: Vintage Books, 1989.

Hofer, Walther. editor. Der Nationalsozialismus Dokumente 1933-19+5. Frankfurt am Main: Fischer Buecherei, 1957.

Hoover, Calvin B., The Economy, Liberty and the State. New York: Doubleday, 1961. "I.G. Farben Officials Indicted for Agression, Murder, Plunder." The New York Times, May 4, 1947, pp. 1, $54 \mathrm{ff}$

"I.G. Farben's Gifts to Nazis are Listed." The New York Times, September 3, 1947, p. 2 Kaestner, Erich. Laerm im Spiegel. Munich: Deutscher Taschenbuch Verlag, 1988.

Kaestner, Erich. Die Kleine Freiheit. Hamburg: Fischer Buecherei, 1952.

Katzenstein, Peter J., Policy and Politics in West Germany. Philadelphia: Temple University Press, 1987.

Kitchen, Martin. Nazi Germany at War. London: Longman, 1995.

Klein, Hans. The German Chancellors. Carol Stream, Illinois: Edition q, inc., 1996.

Kolb Eberhard. The Weimar Republic. Translated from the German by P.S. Falla. London: Unwin Hyman, 1988.

Koehler, Otto. ....und heute die ganze Welt: Die Geschichte der IG-Farben und ihrer Vaeter. Hamburg: Rasch und Roehring Verlag, 1986.

Kolb, Eberhard. The Weimar Republic. London: Unwin Hyman, 1988.

Kolinsky, Martin. Continuity and Change in European Society. New York: St. Martin's Press, 1974.

Kramer, Alan. The West German Economy. Oxford: Berg Publishers, 1991.

Kraus, Karl. Half-Truths and On-and-a-Half Truths, Translated from the German by Harry Zohn. Chicago: The University of Chicago, 1986.

Laqueur, Walter. Russia and Germany. New Brunswick, New Jersey: Transaction Publishers, 1990.

Laqueur, Walter. The Terrible Secret. Boston: Little, Brown and Company, 1980. Lekachman, Robert. Capitalism. New York: Meridian, 1981.

Leonhardt, Rudolf Walter. This Germany. Middlesex, England: Penguin, 1961.

Lewis, Roy, and Stewart, Rosemary. The Managers. New York: Mentor Books, 1961.

Loth, Wilfried. The Division of the World. London: Routledge, 1988.

Lubasz, H., Fascism: Three Major Regimes. New York: John Wiley, 1973.

Ludwig, Emil. The Moral Conquest of Germany. New York: Doubleday, 1945.

Manchester, William. The Arms of Krupp. New York: Bantam Books, 1968.

Marrus, Michael R., The Holocaust in History. New York: Meridan, 1987

Marsh, David. The New Germany. London: Century Ltd., 1989.

Marsch, David. The Most Powerful Bank. New York: Random House, 1992.

Marx, Karl. Die Fruehschriften. Stuttgart: Alfred Kroener Verlag, 1953.

Mason, Tim. Nazism, Fascism and the Working Class. Cambridge, Great Britain: Cambridge University Press, 1995. 
Milward, Alan S., The Reconstruction of Western Europe. Berkely, California: University of California Press, 1984.

Nationalrat der Nationalen Front des Demokratischen Deutschland. Aufsteig und Fall des Heinrich Luebke. Berlin: Staatsverlag der Deutschen Demokratischen Republik, 1969. Nationalrat der Nationalen Front des Demokratischen Deutschland

Dokumentationszentrum der Staatlichen Archivverwaltung der DDR. Braunbuch. Berlin: Staatsverlag der Deutschen Demokratischen Republik, 1968.

Neumann, Franz. Behemoth--The Structure and Practice of National Socialism. New York: Oxford University Press, 1944.

Nobel, David. America By Design. Science, Technology, and the Rise of Corporate Capitalism. New York: Knopf, 1977.

"Obituary." The New York Times, January 9, 1997, p. A131

Overy, Richard. Why the Allies Won. New York: W.W. Norton, 1996.

Piore, Michael J., and Sabel, Charles F. The Second Industrial Divide. New York: Basic Books, 1984.

"Roosevelt Calls For Cartel Curbs." The New York Times, September 9, 1947, p. 10 Rowley, Anthony. editor. The Barons of European Industry. New York: Holmes and Meier Publishers, 1974.

Rubenstein, Richard L., The Cunning of History. New York: Harper Tourchbooks, 1975. Saeltzer, Rolf. editor. German Essays On History. New York: Continuum, 1991.

Sampson, Anthony. Anatomy of Europe. New York: Harper \& Row, Publishers, 1968. Sasuly, Richard. I.G. Farben. New York: Boni and Gaer, 1947.

Schmelzer, Janis., Auschwitz I.G. Farben Massenmord: ueber die Blutschuld der I.G. Farben: Dokumentation zum Auschwitz-Prozess: Berlin, DDR: Das Komitee, 1964.

Schneider, Peter. The German Comedy. Translated by Philip Boehm and Leigh Hafrey. New York: Farrar Straus Giroux, 1991.

Schoenbaum, David. Hitler's Social Revolution. New York: Weidenfeld \& Nicolson, 1967.

Simpson, Christopher. Blowback. Monroe Maine: Common Courage Press, 1993.

Simpson, Christopher. The Splendid Blond Beast. Monroe, Maine: Common Courage Press, 1995.

Smyser, W.R., The German Economy. New York: St. Martin's Press, 1993.

Snyder, Louis L., Encyclopedia of the Third Reich. New York: McGraw-Hill, 1989.

Snyder, Louis L., Hitler's Third Reich. Chicago: Nelson-Hall, 1988.

Snyder, Louis L., The War. New York: Dell, 1964.

Speer, Albert. Inside The Third Reich. Translated from the German by Richard and Clara

Winston. New York: Avon, 1970.

Speer, Albert. Spandau The Secret Diaries. Translated from the German by Richard and

Clara Winston, 1977.

Stern, Fritz.editor. The Varieties of History. New York: Vintage Books, 1973.

Stern, J.P., The Heart of Europe. Oxford: Blackwell Publishers, 1992. 


\section{Page 117}

Stokes, Raymond. Divide and Prosper. Berkely, California: University of California Press, 1988.

Stokes, Raymond. Opting for Oil. Berkely, California: University of California Press, 1995.

Stolper, Gustav. The German Economy :1870 To the Present. Translated from the German by Toni Stolper. London: Weidenfeld and Nicholson, 1967.

Stone, L.F., The War Years 1939-1945. Boston: Little Brown and Company, 1988.

Sutton, Antony C., Wall Street and the Rise of Hitler. Seal Beach, California: '76 Press, 1976.

Tempel, Gudrun. The Germans: An Indictment of My People. Translated from the German by Sophie Wilkins. New York: Random House, 1963.

Tolischus, Otto. "Planned Economy Disliked, Curb on Labor Front Hailed -- General 10-

Hour Day Due." The New York Times, December 22, 1938, p. 13

Turner, Henry Ashby. German Big Business and the Rise of Hitler. New York: Oxford University Press, 1985.

United States National Archives and Records Service. Records of the United States Nuernberg War Crimes Trials: United States of America v. Carl Krauch et al. (case VI) August 14, 1947-July 30, 1948. Washington, D.C.:National Archives Trust Fund Board, General Services Administration, 1977.

Wedekind, Frank. Fruehlings Erwachen. Muenchen: Wilhelm Goldmann Verlag, No date

Weiss, Peter. Die Ermittlung. Frankfurt am Main: Suhrkamp Verlag, 1965.

Williamson, D.G., The Third Reich. London: Longman, 1982.

Wilt, Alan F., Nazi Germany. Arlington Heights, Illinois: Harlan Davidson, Inc., 1994.

Winnacker, Karl. Challenging Years. Translated by David Goodman. London: Sidwick \& Jackson, 1972.

"World News." The New York Times, July 26, 1952, p. 26

Young, John W., Cold War Europe 1945-1989. London: Edward Arnold Press, 1991. 
Page 118

\section{APPENDIX 1: GLOSSARY OF GERMAN TERMS}

Aktiengesellschaft (AG) : a stock corporation. Most are publicly traded, but they need not be.

Aufsichtsrat (AR) : a company's supervisory board, much like a board of directors. Autarky: Economic policy aimed at the highest degree of self-sufficiency, i.e., independence from imports. +

Cartel : combination of firms which, although retaining their separate legal identities, combine to pursue a common policy in their joint economic interests.

Drueben: "over there" - East Germany

Endloesung der Judenfrage : final solution of the Jewish Question $E D G B$ : free organizational union of German workers

Gemeinschaft: 'community' was the traditional form of association that was superseded by the modern society (Gesellschaft). Volksgemeinschaft meant anti-modernism. Gesellschaft mit beschraenkter Haftung (GmbH): privately held, limited liability corporation

Lebensraum : living-space

SED : socialist unity party

Sonderbehandlung: special action

VEB : state production-consumer cooperative in GDR

Vorstand : management board, which includes a company's chief executive along with other top executives. No one from the management board may serve on the same company's supervisory board.

Wiederaufbau: reconstruction 


\section{APPENDIX 2: LETTER FROM SCHMITZ TO HITLER; CONTRIBUTIONS TO HITLER FROM IG FARBEN'S CENTRAL OFFICE, 1933-1944250}

30. September 1938

An den Fuehrer und Reichskanzler

Adolf Hitler

Berlin

Unter dem Eindruck der von Ihnen, mein Fuehrer, erreichten Heimkehr

Sudetendeutschlands ins Reich stellt lhnen di IG-Farbenindustrie Aktiengesellschaft zur Verwndung fuer das sudedeutsche Gebiet einen Betrag von einer halben Million Reichsmark zur Verfuegung.

Hermann Schmitz

(IG Farben Prozess, Dokument NO NI-2795)

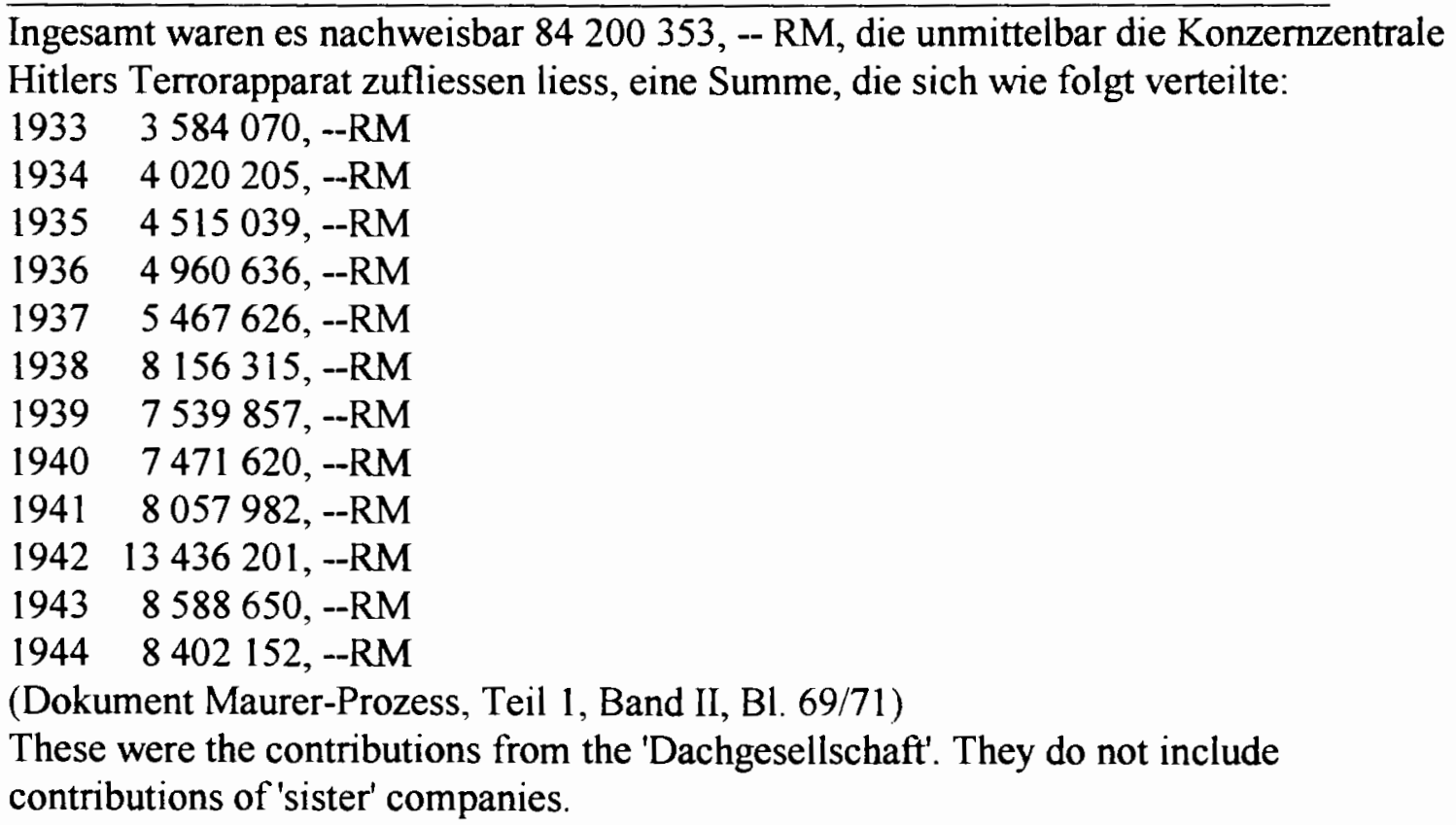




\section{APPENDIX 3: SENTENCES OF I.G. FARBEN BOARD MEMBERS, NUREMBERG WAR CRIMES TRIALS ${ }^{251}$}

Otto Ambros: Guilty of slavery and mass murder, sentenced to imprisonment for eight years. Served eight years.

Heinrich Buetefisch: Guilty of slavery and mass murder, sentenced to imprisonment for six years. Served six years.

Walter Duerrfeld: Guilty of slavery and mass murder, sentenced to imprisonment for eight years. Served eight years.

Paul Haefliger: Guilty of plunder and spoliation, sentenced to imprisonment for two years.

Friedrich Jaehne: Guilty of plunder and spoliation, sentenced to imprisonment for one and one-half-years.

Carl Krauch: Guilty of slavery and mass murder, sentenced to imprisonment for eight years. Served eight years.

Hans Kugler: Guilty of plunder and spoliation, sentenced to one and one-half years. Heinrich Oster: Guilty of plunder and spoliation, sentenced to imprisonment for two years.

Hermann Schmitz: Guilty of plunder and spoliation, sentenced to imprisonment for four years.

Georg von Schnitzler: Guilty of plunder and spoliation, sentenced to imprisonment for five years.

Fritz ter Meer: Guilty of plunder and spoliation, and count three, slavery and mass murder, sentenced to imprisonment for eight years. Pardoned---seven years. 


\section{APPENDIX 4: POSITIONS OF FARBEN BOARD MEMBERS BEFORE AND AFTER 1945}

Ambros, Otto:

Before 1945: Production chief, buna rubber and poison gases; Executive Manager of IG Farben-Industrie,AG, Auschwitz After 1945: Positions in several major German companies, such as Telefunken, AG; Advisor as of 1951 to the Bonn government

Biedenkopf, William: Before 1945: Director of I.G. Farben Industrie, AG, Frankfurt-amMain. After 1945: Mamber of managing board of three German companies, including Dynamit Noble, AG (Flick concern)

Buetefisch, Heinrich: Before 1945: Member of managing board, IG Farben, Frankfurtam-Main; Lieutenant-Colonel in the SS. After 1945: Member of the supervisory board of two German chemical companies

Duerrfeld,Walther: Before 1945: Director and construction manager of FarbenIndustrie AG, Werk Auschwitz. After 1945: Board member of two German chemical companies

Eisfeld, Kurt: $\quad$ Before 1945: Leading chemist in Farben Industrie, AG, Werk Auschwitz. After 1945: Board member, two Flick companies.

Jaehne, Friedrich: Before 1945: Chief engineer, construction and physical plant development. After 1945: Honorable member of the supervisory board, Hoechst Farbenwerk, AG.

Kugler, Hans: $\quad$ Before 1945: Organizing manager of Farben's "newly acquired" European plants. After 1945: Executive of two German companies.

Ter Meer, Fritz: Before 1945: Chief, Technical Committee which directed all I.G. Farben production. After 1945: Honorary executive for Bayer, AG, a Farben company.

Winnacker, Karl: Before 1945: Director of Farbewerke Hoechst, AG, Frankfurt. After 1945: Same position.

Wurster, Carl: $\quad$ Before 1945, Technical Director, inorganic factories; Assistant to Ambros in development of chemical warfare agents. After 1945: Managing Board Chair, BASF (a Farben company) 
Page 122

\title{
APPENDIX 5: ORDER FOR THE DECONCENTRATION OF I.G. FARBEN
}

\author{
MILITARY GOVERNMENT - GERMANY \\ UNITED STATES ZONE \\ GENERAL ORDER No. 2 \\ (PURSUANT TO MILITARY GOVERNMENT LAW NO. 52 - BLOCKING \\ AND CONTROL OF PROPERTY) \\ I. G. FARBENINDUSTRIE A.G. ${ }^{252}$
}

WHEREAS, it is the main objective of the United Nations to prevent Germany from ever again disrupting the peace of the world;

WHEREAS, I.G. FARBENINDUSTRIE A.G. played a prominent part in building up and maintaining the German war machine;

WHEREAS, through its world-wide cartel system and practices, I.G. FARBENINDUSTRIE A.G., as a deliberate part of Germany's bid for world conquest, hampered the growth of industry and commerce of other nations and weakened their power to defend themselves;

WHEREAS, the war-making power represented by the industries owned or controlled by I.G. FARBENINDUSTRIE A.G. constitutes a major threat to the peace and security of the post-war world so long as such industries remain within the control of Germany;

WHEREAS, it is essential to the objectives of the United Nations to take over the direction and control of I.G. FARBENINDUSTRIE A.G. and to seize possession of its property in order to bring about its destruction and the war-making potential which it represents; and

WHEREAS, it is intended that the property seized will be placed at the disposition of the Control Council (Germany), when such action is desired by the Control Council; IT IS HEREBY ORDERED:

1. All the property within the United States Zone in Germany owned or controlled, directly or indirectly, by I.G. FARBENINDUSTRIE A.G., a corporation organized and existing under and by virtue of the laws of Germany with seat and head office at Frankfurt am/Main, is hereby specified under paragraph 1 (g) of Military Government Law No. 52 to be subject to seizure of possession, direction, and control of the by Military Government.

252 Sasuly, pp. 264-265 
Page 123

2. The direction and control of I.G. FARBENINDUSTRIE A.G. and the possession of all its property in the United States Zone are hereby seized by the Military Governor, United States Zone.

3. Pending the assumption of control of such property by the Control Council, or an agency thereof, all the powers of the Military Governor, United States Zone, with respect to the property seized pursuant hereto and with respect to the direction and control of the corporation are hereby delegated to the Deputy Military Governor, United States Zone. Redelegation of any or all such powers is hereby authorized. In the exercise of such powers, the Deputy Military Governor, United States Zone, or any person acting by or under his authority with respect to the property affected hereby shall not be subject to German law.

4. In the exercise of such powers the Deputy Military Governor, or any person acting by or under his authority with respect to such property, shall be guided by the general objectives stated in the preamble hereof and by the following specific objectives, and will take such measures as he deems appropriate to accomplish them:

a. The making available to devastated non-enemy countries of Europe and the United Nations, in accordance with such programs of relief, restitution, and reparations as may be decided upon, of any of the property seized under this order and, in particular, of laboratories, plants, and equipment which produce chemicals, synthetic petroleum and rubber, magnesium and aluminum, other non-ferrous metals, iron and steel, machine tools and heavy machinery.

b. Destruction of all property seized under this order and not transferred under the provisions of paragraph a above if adapted to the production of arms, ammunition, poison gas, explosives, and other implements of war, or any parts, components, or ingredients designed for incorporation in the foregoing, and not of a type generally used in industries permitted to operate within Germany;

c. Dispersion of the ownership and control of such plants and equipment seized under this order as have not been transferred or destroyed pursuant to paragraphs $a$ and $b$ above.

5. a. The entire management of I.G. FARBENINDUSTRIE A.G., including but not limited to the supervising board (Aufsichtsrat), the board of directors (Vorstand), and directors (Direktorium) and all other persons, whether office-holders or not, who are empowered, either alone or with others, to bind or sign for on behalf of I.G.

FARBENINDUSTRIE A.G. are forthwith removed and discharged and deprived of all authority to act with respect to the corporation or its property.

b. The rights of shareholders in respect of selection of management or control of I.G. FARBENINDUSTRIE A.G. are suspended.

6. Article IV of Military Government Law No. 5 shall not be applicable to any property or enterprise affected by this General Order.

7. This General Order shall become effective on 5 July, 1945. BY ORDER OF MILITARY GOVERNMENT 


\section{APPENDIX 6: TRANSLATIONS OF GERMAN TEXT BY FOOTNOTE 253}

\section{FOOTNOTE}

\#2 You dare to print such books!

Truest friend, you are lost!

If you want money and honor

Then you must pay the cost!

\# 6 Where would the Holy Ghost be if He had to be present at everyone's personal beck and call?

\# 8 The (written) history of all former societies is the history of class struggle.

\#25 For whom, you good German folk

Ladens you with weapons?

For whom do you leave your wife, and child and have your cattle taken?

\#39 One should never lose one's dignity -- Regarding morality, I understand it as the real product of two imaginary powers. The imaginary powers are should and would. The product is called morality, and no one is permitted to deny its reality.

\#52 ...that the I.G. should follow a course which did not ring in unison with the government was unthinkable - and that the I.G. would have deviated from a government order, or that the company might have taken an open or secret opposing position - was out of the question. It was the same when Germany was a democratic state in which the government's standards could be easily criticized. The I.G. was equally true to the governments under Stressemann as under the rule of Bruening and Papen.

\#72 Carl Duisberg had a nervous disposition. He was political, a well organized and exact thinker. At the same time, he was an especially engaging entrepreneur. Carl Bosch was a scientist, a technical-type and a genius with all the merits and weaknesses of such a person. The two men

253 Translations by Robert Arthur Reinert 
contrasted and clashed sharply. Yet they had a love-hate relationship, and were careful not to offend each other.

\#73 founder and leader of the large chemical industry in Germany.

\#77 On the long train ride to Munich, Buetefisch and I discussed the I.G., especially regarding the new processes. We had prepared our talk with Hitler as much as possible. We didn't expect too much since up to this point we viewed the National Socialists as chaotic and against us.

\#82 That the meeting with Hitler in June happened, according to documentation, was also not challenged by Buetefisch. But Gattineau was somewhat confused regarding the dates of the meeting. And if, as he maintained, the attack of National Socialist publications against the I.G. was supposed to be the single cause for the meeting, then why did one wait until Fall with the complaint? The last known National Socialist article against the I.G. originated in March, 1932.

\#83 The consumers are the left hand of the societal organism, the producers are the right hand.

\#126 personified the unity of the party, state and the "community of interests."

\#136 Since 1934, I served in the administration of concentration camps. I served in Dachau until 1938; then as adjutant in Sachsenhausen from 1938 until May 1, 1940, at which time I was named commandant at Auschwitz. I commanded Auschwitz until December 1, 1943 and I reckon 2,500,000 people were executed and exterminated. At least another 500,000 died from hunger and sickness. The entire number of deaths totaled about $3,000,000$. This is about $70-80 \%$ of all persons there, who, on top of it, were used as slaveworkers in the industries which the concentration camps served.

\#140 celebrated the company's 50th anniversary with the SA.

\#141 Without the I.G. Farben, particularly in the fields of fuel and magnesium, it would have been out of the question for Germany to initiate a war.

\#158 I spoke often with D. Ambros while I was present in Ludwigshafen in 1941. To my knowledge, Dr. Ambros was entrusted with responsibility for the entire Buna Production for I.G. Farben. During my time there, he 
visited the camp at Auschwitz two or three times. I saw him at various times at the Buna operations in Auschwitz.

I'm certain that Dr. Ambros knew as much as all the other visitors to Auschwitz about the annihilation of human lives at Birkenau. This information was known in the city of Auschwitz, at the Buna plant and in the vicinity of the camp. Stories of exterminations were commonly discussed.

\#160 The normal work week averages between 56-58 hours, while some companies work 70 hours.

\#161 In some branches of industry, the workload is almost impossible to bear In the iron and steel plants work hours have been expanded to 12 hours. At the same time, many workers have a five to fifteen kilometer journey to and from work. Most of them must also take care of some farming chores. It is understandable that such demands cause ill feelings. At times, compulsory service in the German work-force must also be administered by police coercion.

\#175 The Nuremberg war crimes trials are a tragic derision of American justice.

\#180 Under your direction, my leader, the Sudetenland has been returned "home" to the Reich. For use of this area, I.G. Farben places half-million Reichsmarks at your disposal.

\#189 The times of ignorance came, at which one gazed in amazement again.

\#193 Germans against Germans is not a road to peace.

\#204 In the I.G. Trial, ten defendants were freed while the remaining thirteen former directors received sentences from one and a half to eight years.

\#220 ... and here the matter rests, regarding the German point of view which is essential to this trial. This is not about individual businessmen, but about maintaining the good names of famous German companies.

\#221 Their appetite is boundless

They eat God and the world

They sow nothing. They harvest nothing

They impregnate their own capital. 


\section{Page 127}

\#236 "We must 'chew' through the proceedings again." "Please spare me!"

\#237 "My life is always on history's course, not controlled by me."

\#245 as a 17 year old in 1947 , he co-founded the Young Union (CDU youth organization..

\#247 from 1940-1945, department head of the foreign ministry's political division of radio broadcasting--in association with the propaganda ministry.

\#248 unquestioning National Socialist to the first degree.

\#249 With this course of action, the I.G. assumed great accountability and set up the essential and decisive help for Hitler's foreign policy, which led to war and Germany's ruin. So then I must conclude that the I.G. is largely accountable for Hitler's politics. 


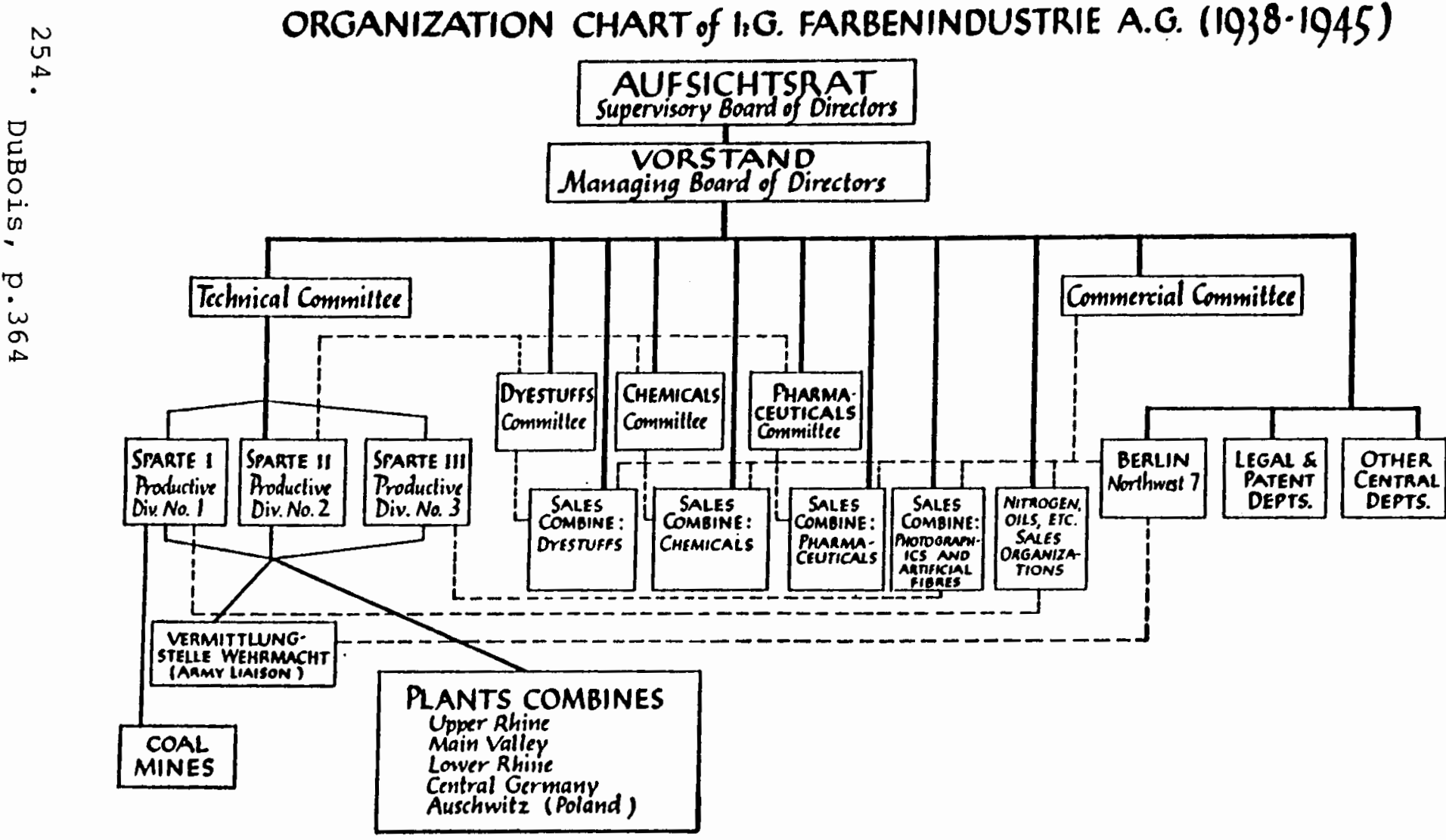

